Maurice A. Deane School of Law at Hofstra University Scholarly Commons at Hofstra Law

Hofstra Law Faculty Scholarship

Summer 2001

\title{
Beyond the Counter-Majoritarian Difficulty: Judicial Decision-Making in a Polynomic World
}

Daniel J.H. Greenwood

Maurice A. Deane School of Law at Hofstra University

Follow this and additional works at: https://scholarlycommons.law.hofstra.edu/faculty_scholarship

\section{Recommended Citation}

Daniel J.H. Greenwood, Beyond the Counter-Majoritarian Difficulty: Judicial Decision-Making in a Polynomic World, 53 Rutgers L. Rev. $781(2001)$

Available at: https://scholarlycommons.law.hofstra.edu/faculty_scholarship/169

This Article is brought to you for free and open access by Scholarly Commons at Hofstra Law. It has been accepted for inclusion in Hofstra Law Faculty Scholarship by an authorized administrator of Scholarly Commons at Hofstra Law. For more information, please contact lawcls@hofstra.edu. 


\section{RUTGERS LAW REVIEW}

\section{BEYOND THE COUNTER-MAJORITARIAN DIFFICULTY: JUdiclal Decision-Making in A POLYNOMic WoRLd}

\section{Daniel J.H. Greenwood*}

This Article examines the role of judicial deference in a modern democracy. The Author disputes the view that judges defer to legislatures because legislatures are more majoritarian than judges. In refuting this view, the Author first outlines a theory of democracy as partnership. He then describes and discusses the main decisionmaking processes of a modern democracy, including aggregation processes such as majoritarian politics, economic markets, and civil society, as well as normative systems such as judiciaries, bureaucracies, and professionals, emphasizing the failure of each, taken alone, to satisfy democratic ideals. The Author contends that in order to understand and appreciate the role of judicial deference, we must distinguish judicial reasoning from these other decisionmaking institutions. While the boundaries between these institutions are quite flexible, often overlapping, and sometimes incoherent, the distinctions between them need not (and can not) be disregarded if we are to understand and appreciate the implicit natures and individual characteristics of each. The Author suggests that reinflating the collapsed distinctions between these institutions will set the groundwork for a new and improved analysis of each.

* Professor of Law, University of Utah College of Law; J.D. Yale Law School, 1984; A.B. Harvard College, 1979. This article was made possible by the generous support of the University of Utah College of Law Research Stipend Program. I am deeply grateful for research assistance provided by the College of Law library, for the support of my colleagues, several of whom read part or all of the manuscript, in several cases more than once, for the comments at a University of Utah College of Law Brown Bag Presentation, and to useful discussions at the Sloan Program for the Study of Business in Society at the George Washington University Law School summer retreat. Particular thanks to my colleagues Leslie Francis and Mitchel Lasser for their extensive discussion and comments. 


\section{TABLE OF CONTENTS}

I. INTRODUCTION: RECONSTRUCTING THE LAW/POLITICS DISTINCTION, OR, WHAT DO JUDGES DO?

II. BEYOND THE COUNTER-MAJORITARIAN DIFFICULTY...................784

A. The Inadequacy of Counter-Majoritarian Theory ..............784

B. Pluralist Institutions in a Polynomic World ....................788

III. AGGREGATIVE AND NORMATIVE DECISION-MAKING SYSTEMS .. 789

A. Political Democracy as Partnership .................................790

1. The Teleology of Democracy and its Competitors......795

2. Equality of Membership in Democracy as Partnership

3. Implementing Democratic Equality.

B. Democracy, Majoritarianism, and its Problems 803

1. The Majoritarian Difficulty 803

a. The Winner-Take-All Problem .804

b. The Might-Does-Not-Make-Right Problem 809

c. The Boundary Problem

2. Democracy's Discontent

C. Markets and Their Failings

1. Market Impersonality versus Democratic Concern ...812

a. Affirmative Action from Market and Political Perspectives

b. Market Equality versus Democratic Equality......815

2. Market Difficulties.

a. Aggregation Errors

b. Collective, Non-Aggregative Results

c. The Majoritarian Difficulty and Boundary Problems in Markets.

1. The Boundary Problem I: Background Conditions to Make Choices Voluntary.

2. The Boundary Problem II: Protection Rackets and Free Markets

3. Voluntary Markets, Private Power, and Redistribution

a. Voluntary Transactions and Upward

Redistribution: How the Rich Get Richer

D. Civil Society: Aggregation by Membership and Governance by Exit

E. Normative Systems

1. Normativity and Deference

2. Polynomic Normativity and its Discontents

3. Normative and Aggregative Decision-Making Processes Compared

a. To What to Defer?

b. Why Defer? 
DEMOCRACY

V. THE DIVISION OF POWERS AFTER THE COLLAPSE OF THE

LAW/POLITICS DISTINCTION

A. The Law/Politics Distinction. 856

B. The Law/Markets or Politics / Economics Distinctions ...859

C. The State/Society or Public/Private Distinctions 860

D. Beyond the Collapsed Distinctions 861

\section{INTRODUCTION: RECONSTRUCTING THE LAW/POLITICS}

DISTINCTION, OR, WHAT DO JUDGES DO?

Why do judges defer to law and regulations passed by legislatures and agencies? The standard answer is that the judiciary is a counter-majoritarian institution: judges should allow the representatives of the people to rule. But the standard answer is a puzzle: judges are also representatives of the people, and they often have a stronger claim to democratic authority than the statutes or other norms to which they defer.

A broader look at the various decision-making institutions we use-not merely judges and legislatures, but private and public bureaucracies, professionals, market and non-market competitions, voting, lotteries, and exit-suggests a different answer. Each of these institutions expresses a different, and partial, attempted solution to the problem of democratic rule in a pluralist society. Judges defer not because they are less majoritarian than legislatures, but because they are a different type of institution altogether. Deference is part of what makes a judge a judge.

Rather than elevate one institution or its associated value(s) above the others, I seek to reconstruct a sense of their incommensurability. Reconstruction is nearly impossible, however, in a post-Realist world suffering from the collapse of the public/private, state/society, law/politics, and other related distinctions. If judges are not doing anything different than legislatures, there is no point in talking about incommensurable roles. If politics is nothing more than economics (or economics is nothing more than politics), there is no point in attempting to restrict them to separate spheres. Without some distinction between state power and private power, each may be understood as nothing more than the other. I do not attempt a full theoretical explanation. Rather, I approach the problem from the back end. By describing the institutions that reflect the (intellectually) collapsed distinctions, I think we can begin to rebuild distinctions and separations that we need without reverting to a preModern faith in reified categories.

The task is much the same as that faced by the second year law student: he or she knows that the law provides no firm answers, that the professor can always make you look like a fool, and that there are 
good arguments on both sides of every important question. But still, the successful student understands that it does not follow that there are no wrong answers, or that all arguments are the same, or that courts are (entirely) unpredictable, or, most importantly, that purely political appeals will fly in a law school exam or a courthouse argument.

We too must find a way to distinguish majoritarian politics from judicial reasoning, economic markets, and the competition and cooperation of civil society, even while knowing that their boundaries are flexible, often overlapping, and indeed sometimes incoherent. Each can be re-characterized in terms of the others, but we must nonetheless retain a sense of their separateness.

Our most important decision-making systems can be divided usefully into aggregative and normative systems. Each has characteristic virtues and vices; I hope that setting them out briefly will help to illuminate what each is trying to do, why we retain them, why we argue over how to restrain them, and ultimately, in what sense the collapsed distinctions can be re-inflated.

\section{BEYOND THE COUNTER-MAJORITARIAN DIFFICULTY}

\section{A. The Inadequacy of Counter-Majoritarian Theory}

The leading explanation of judicial deference rests on a claim that the judiciary is counter-majoritarian, and therefore suspect in a democracy. However, judges often seem to have majoritarian credentials at least as good (and often far better) than the institutions whose actions they review. Were deference in fact due to the judiciary's "deviant" status, judges presumably would not defer when they are just as majoritarian. They do not. Thus, the counter-majoritarian claim fails to explain either the actual institutional workings of our system or its theoretical underpinnings.

Within the federal government, the majoritarian credentials of judges are not obviously weaker than those of the Congress. Most importantly, judges reflect a national constituency. The President, our only nationally elected official, appoints the federal judiciary and judicial nominees (particularly at the Supreme Court level) are subject to a national debate. In contrast, Congressmen and Senators are elected by local constituencies that can make no claim to represent a national electorate. Even aside from their unrepresentativeness, those local elections may turn on entirely local issues or local constituent services with no national implications. Moreover, taken collectively, the Senate is defiantly anti-majoritarian. The Senate's one state/two votes system is compounded by the effects of seniority, so that we are often confronted with the deeply undemocratic spectacle of national legislation created or held up by a powerful committee 
chair answerable only to a small, one-party state. While the House seems more democratic on its face, there too the committee and seniority system can grant inordinate power to representatives from nationally unrepresentative one-party districts.

Nor does the fact that the federal judiciary is appointed make it clearly less majoritarian than its competitors. The administrative branch, of course, is not elected; indeed, much of the rule-making civil service is in effect just as tenured as the judiciary. Even in the elective branch, the advantages of incumbency seem to give many Congressmen and Senators virtual tenure-and then seniority gives the most entrenched the most power.

In our federalist system, federal judges often review state actions. Federal judges again are not obviously less majoritarian than the state officials whose actions they review. Federal judges are only indirectly elected, but the ultimate constituency behind them is national. State governments, even if they could be imagined to represent their constituencies perfectly, represent only a part of the American people. A federal judge applying national law and answerable (even if only weakly) to national institutions and national opinion may better represent the will(s) of the people than a state that is out of line with the American mainstream.

Furthermore, even aside from regionalism issues, state legislatures may have relatively weak democratic credentials. State governments admittedly sometimes have a claim to being closer to (a part of) the people. However, the combination of our national press, sound-bite television journalism, and limited attention spans suggests that often the reverse will be true. State governments may be able to act without public scrutiny. State officials may be elected in less ideologically clear or less well-reported campaigns. And that lack of scrutiny and citizen participation may lead to state governments acting under the influence of well-funded special interest groups that represent money, legal constructs or concentrated interests rather than votes. There is no a priori reason to believe that federal judges will automatically be less representative of the wills of the people (or their majorities) than these other officials.

State judges are even more obviously the majoritarian equals of their legislative and executive colleagues: in most states they are elected for limited terms. State supreme court justices usually are elected by state-wide electorate, giving them a state-wide claim to majoritarian representativeness that is stronger than that of lowvisibility locally elected legislators, let alone appointed executive branch rule-making authorities.

The problem goes beyond the relative majoritarianism of judges and other governmental officials: it extends to the relative merits of case law as opposed to statutes and regulations. Federal judges are 
often said to be counter-majoritarian because they are appointed for life. But even life appointment is not enough to establish that the judiciary is a relatively less majoritarian institution than the political branches it reviews. The laws the Congress passes remain on the books for longer than life: a judge reviewing or interpreting a statute or constitutional provision will often have faced the voters more recently than did the text. Weak as the judge's majoritarian credentials may be, they surely are stronger than those of a statute passed by the dead.

Furthermore, some areas of law have particularly thin democratic credentials. Our national corporate law is ratified only by Delaware's legislature, which does not represent most of us even indirectly. Corporate law, in turn, sets the standards for entity liability, thus defining economic actors and determining the extent to which they are responsible for their actions-in other words, the extent to which nearly every other branch of law will be enforceable or meaningful. Furthermore, by determining the governors of our national corporations and setting their electorates and responsibilities, Delaware corporation law determines much of the character of our economy and our lives as employees, investors, and consumers. Any judge with even an indirect connection to an electorate has better majoritarian credentials than Delaware corporate law. If the countermajoritarian problem were the source of judicial deference, judges would be well advised not to defer at all to corporate law.

Indeed, some of our law has no majoritarian credentials at all. Judges routinely defer to common law predating the institution of elections. Some of our most influential law is written by un-elected Uniform Law Reporters and merely ratified by legislatures under enormous pressure to accept what an entirely unrepresentative body did. A great deal of statutory law and virtually all of our Constitution date from periods in which the executive and legislatures did not even purport to be majoritarian: universal adult suffrage and fair apportionment are not yet forty years old in much of this country (fair apportionment has yet to reach our Senate).

Theories of tacit consent are often used to democratically justify old enactments: if the current legislature disapproved of the common law, or the old statute, it would have changed it, and so we should treat non-repeal as democratically equivalent to majoritarian approval. Whatever the merits of that argument-since most of our law-making forums are steeply stacked against action, they are fewthe issue here is relative majoritarianism. If failure to repeal endows an old statute or common law principle with new democratic status, then failure to impeach should do the same for judges and failure to overturn should do the same for new judicial decisions. A state judge elected (or even a federal judge appointed by the President) within 
living memory and not impeached since then has the same majoritarian credentials as an old statute.

Judges defer even in these instances where the countermajoritarian difficulty seems to counsel the opposite of deference. Furthermore, judicial opinions never suggest that more or less deference might be appropriate in situations where the judge's majoritarian credentials are relatively weaker or stronger.

Thus, elected state judges rarely suggest that their election entitles them to exercise less deference; recently appointed federal judges do not claim that the date on which the Senate ratified their nomination entitles them to be more independent than those less recently before the electorate; and state supreme courts, elected by broader constituencies, do not cite that as a justification for ignoring legislative enactments (or even other court opinions). When then-Professor Guido Calabresi proposed that judges could sometimes be less deferential to older statutes, a position clearly justified by any explanation of the judicial role that relies on counter-majoritarianism, even Judge Guido Calabresi was unwilling to apply the proposition. ${ }^{1}$

Indeed, Judge Calabresi is not unusual in his unwillingness to be explicitly activist even where majoritarianism seems to demand it: it

1. Compare Guido Calabresi, A COMmon LAW for the Age of StatuTes 163$66,172-77$ (1982) (discussing the judge's role in deciding whether to apply or amend obsolete statutes), with Quill v. Vacco, 80 F.3d 716, 735 (2d Cir. 1996) (Calabresi, J., concurring) (stating that as a judge, ordinarily he would not rid the system of laws which remained on the books due to "inertial force" rather than "majoritarian support" in the absence of legislative authorization), rev'd, 521 U.S. 793 (1997). Calabresi, however, was prepared to exercise what he refers to as a "constitutional remand": overturning an older statute while stating that he would or might defer to a subsequent legislative judgment to the contrary. Id. at 738. Clearly, courts do occasionally act in this way, reconsidering their constitutional holdings in the face of legislative disagreement. E.g., id. However, majoritarianism does not seem to offer a sufficient explanation for when the courts will or will not accept legislatures as legitimate interpreters of constitutional law. Compare City of Boerne v. Flores, 521 U.S. 507, 512, 515, 519 (1997) (overturning the Religious Freedom Restoration Act of 1993 (the "RFRA") and rejecting Congressional participation in interpretation of the Free Exercise Clause, U.S. CONST. amend. I, notwithstanding the highly visible passage of the RFRA in explicit reaction to the United States Supreme Court decision in Employment Div., Dep't of Human Res. v. Smith, 494 U.S. 872 (1990)), and Rosebud Sioux Tribe v. South Dakota, 900 F.2d 1164, 1172 \& n.14 (8th Cir. 1990) (accepting Calabresi's contention that older statutes must be considered in light of post-enactment changes in the "legal fabric"), with Ill. Council on Long Term Care Inc. v. Shalala, 143 F.3d 1072, 1075 (7th Cir. 1998) (noting that the Supreme Court has rejected Calabresi's suggestion that the Court sometimes treats statutes as if they were common law), and United States v. Fountain, 840 F.2d 509, 520 n.4 (7th Cir. 1988) (stating that "[d]espite Dean Calabresi's provocative suggestion to the contrary . . . Congress rather than the courts still is in charge of keeping statutes up to date."), and N. Ind. Pub. Serv. Co. v. Carbon County Coal Co., 799 F.2d 265, 274 (7th Cir. 1986) (acknowleging that "[w]e do not believe that we have the power to declare a constitutional statute invalid merely because we, or for that matter everybody, think the statute has become obsolete."). 
is virtually impossible to find a judicial opinion that proudly denies deference. Aristocrats may be proud, republicans may be independent, and democrats may be self-reliant, but judges in their selfdescription are always deferential. No judge ever writes "I am deciding this way because it fits with my political beliefs or those of the party that sponsored my appointment" or "I was elected to change this law"-those are always attacks from the other side. The debate that was briefly mischaracterized as "interpretivist v. noninterpretivist," "original intent v. activist," or even "originalist v. nonoriginalist" is not about deference: nearly all of the academic proponents and even more of the judicial ones claim to be deferential. They accuse only their opponents of imposing political views in the name of law. Rather, the debate is about the norms to which judges ought to defer and the techniques they ought to use to determine and explicate them.

In short, the counter-majoritarian explanation does not seem to explain either actual judicial behavior or popular understandings of it. Judges defer regardless of their democratic credentials. They nearly always claim that they are being deferential (and generally seem to make the claim in subjective good faith) even when it seems obvious to their critics that they are not. Nor does the countermajoritarian explanation illuminate the ultimately more significant debates over how to read the constitution: judges agree that they ought to defer to the constitution and the laws even as they disagree over what the content of that deference might be.

\section{B. Pluralist Institutions in a Polynomic World}

The failure of counter-majoritarian theory to explain the actual patterns of deference in judicial decision-making should suggest that the theory needs to be examined more carefully. But the problem is deeper than merely an ugly fact interfering with a beautiful theory. The counter-majoritarian critique of the judiciary judges the judges according to the standards of the legislature. Instead, the judiciary ought to be judged by standards of the judiciary. If judges were no more than inferior legislatures, they would indeed be a truly anomalous institution-one that should be limited more severely (and not just in constitutional review) than any but the most extreme critics have ever suggested.

The dominant views-not merely the majoritarian defense of judicial deference, but public choice attacks on regulation, populist attacks on the market, even the leading defenses of judicial activismeach rely on a uninomic hierarchy of values. Each of these theories contends that one value should be the measure of the others. Which value is hierarchally elevated varies by the theory-thus, the counter-majoritarian theorists assume that majoritarianism can be 
used to test all our institutions; economists take efficiency as a universal measure; Rawlsians test every primary social institution against justice as fairness. ${ }^{2}$ Competing institutions are then condemned for insufficiently embodying the chosen value: judges are insufficiently majoritarian, regulators are insufficiently efficient, and legislatures are insufficiently just.

I seek to contest all those models simultaneously. Our multiple institutions reflect an underlying understanding that we have commitments to multiple, not always commensurable, values: majoritarianism and justice, community and individualism, efficiency and continuity, and so on. It seems to me that a decent society cannot put any one of these incommensurable values in a position of supremacy, but must allow them to compete and conflict, hopefully - but never automatically - ending up in a reasonable balance. The issue, then, is not whether judges or legislatures (or markets or civil society) ought to be supreme, but rather to describe the proper spheres of each.

The stakes are high. One could imagine a system that enshrined one value above others: England, for example, formally places majoritarianism above competing values. In their uninomic system of parliamentary supremacy, subordinated courts are unlikely to pose a serious threat to legislative hegemony. In a dynamic system such as ours, however, there can be no guarantee that any particular institution will be victorious consistently. Because we do not know in advance which institution ought to win any particular conflict, there can be no guarantee that the right one will. ${ }^{3}$

\section{AgGREGative AND Normative DeCision-MaKing Systems}

Part III describes the leading decision-making systems we use. I contend that they are best understood as attempts to embody different and incommensurable values: by describing them I hope to show why each is both desirable and flawed, and most importantly, why none should be viewed as automatically entitled to rule the others.

Modern capitalist democracies have four principal authoritative collective decision-making systems: three aggregative systems and several related normative systems. The aggregative systemsmajoritarian electoral democracy, the economic market, and a competitive or cooperative system often referred to as "civil society"-

2. See, e.g., JOHN RAWLS, A THEORY OF JUSTICE 3-22 (1971) (expanding on the general proposition that "law and institutions no matter how efficient and well arranged must be reformed or abolished if they are unjust").

3. Small changes in roles can have large changes in results. As an old joke puts it, in Heaven, the Italians cook the food and the Germans run the trains; in Hell, it is the other way around. Nearly everyone seems to agree that when courts act like legislatures, or the reverse, we are heading away from political heaven. The issue is to define what it means to act like a court or like a legislature. 
each function by cumulating the values, desires or preferences of individuals, although majoritarian representative democracy, civil society and the market each aggregate in radically different ways. Normative systems applied by the judiciary, bureaucrats and professionals generally, in contrast, seek to apply a pre-existing norm found somewhere else: they do not aggregate the participants' values or preferences but rather demand that they set them aside. In Part III.A, I begin by discussing the ideal of democracy generally; in Parts III.B through III.E, I then examine each of these four principal governance systems in terms of their conformity to this ideal.

\section{A. Political Democracy as Partnership}

Democracies ${ }^{4}$ express a particular understanding of equality: all citizens (but possibly not non-citizens) are equally members of the political community and accordingly ought to have equal say in its public character and future course ${ }^{5}$ Like a partnership, a democracy is a common enterprise created by and for its members; since each citizen is just as much a member as each other one, it is appropriate for each to have an equal voice in determining the common aim.

Equal membership-the partnership principle-distinguishes democracy from other governmental forms. In a democracy, citizens share the key characteristics of partners. They are the enterprise, in the sense that it has no existence apart from them, no aims or goals apart from theirs, no interest apart from theirs, and no source of authority or legitimacy apart from them. They are, thus, its governors and owners - they or their delegates can set and change its purposes and they alone are the intended beneficiaries of its actions. ${ }^{6}$ (Many

4. I use the word "democracy" broadly to encompass a variety of popularly based regimes, and reserve the word "majoritarian" for the specific democratic technique of decision-making by direct or representative elections. Hopefully this will enable me to distinguish between the general goal of democracy and the specific means, including majoritarian elections, of reaching those goals.

5. I oversimplify the notion of membership in this part of the text by ignoring our multiple and often conflicting memberships: we are members (or citizens) not only of states (more than one, in federal systems such as our own) but of larger groups (the European Union is a particularly clear supra-national organization), smaller ones (families), and cross-cutting ones (such as multi-national corporations or (only partly state-based) national, religious or ethnic groups). For further discussion, see Linda Bosniak, Citizenship Denationalized, 7 IND. J. Global LEGal STUD. 447 (2000) (analyzing concepts of "postnational citizenship" and of citizenship as membership).

6. Our Federal Constitution and the social contract theory of the state that informs it invoke partnership concepts. First, social contract theorists ground the legitimacy of the state in an associative act (even if imaginary) of the people themselves, not in a grant from a higher authority or irrational tradition: "We the People ... do ordain and establish this Constitution..." U.S. CONST. pmbl. Non-democrats reject this claim. See, e.g., JOSEPH DE MAISTRE, ON GOD \& SOCIETY xxvii, 3, 18 (Elisha Greifer ed., Henry Regnery Co. 1959) (1809) (denying that any government can be created by 
rights-based theories place all humans, citizens or not, on an equal basis; I understand them as claiming that we are members of a broader group: citizens of the world, as Martha Nussbaum has put

agreement). Similarly, under section 6 of the Uniform Partnership Act (the "UPA"), a partnership is created by the partners themselves, without any permission, action, or registration of governmental or other outside authorities. UNIF. P'SHIP ACT $\S 6(1)$ (1914); REVISED UNIF. P'SHIP ACT § 202(a) (1996).

Second, social contract theories emphasize the essential equality of all the members of society: at least at the beginning or in the abstract, all rational citizens should be able to see that they would have agreed to the basic social arrangements. See, e.g., JOHN LOCKE, SECOND TREATISE OF GOVERNMENT 13-14 (§ 15), 52 (§ 95) (C.B. Macpherson ed., Hackett Publ'g Co. 1980) (1690) (asserting that an agreement is necessary to leave the state of nature); RAWLS, supra note 2, at 139 (explaining "veil of ignorance" as a device to assure unanimous agreement in hypothetical negotiations); ROBERT NOZICK, ANARCHY, STATE, AND UTOPIA 5-7, 33, 151, 160-64 (1974) (arguing that just distribution involves a system based on voluntary agreements in which "[t]here is no justified sacrifice of some of us for others."). Similarly, under the UPA, all partners must agree to the initial partnership agreement and all significant changes. UNIF. P'SHIP ACT §§ 18(h), 31 (1914); REVISED UNIF. P'SHIP ACT §§ 401(j), 601(1), 602 (1996) (stating that a partnership agreement, and changes to it, must be agreed to by all partners; each partner retains the inalienable right to withdraw); cf. LOCKE, supra, at 87 ( $\$ 168$ ) (asserting that people always retain right to appeal to Heaven, i.e., to use legitimate violent resistance against illegitimate rulers).

Third, social contract theories, like the UPA, assert that each member, at least as a defauit rule, has equal rights. UNIF. P'SHIP ACT $§ 18(e)$ (1914); REVISED UNIF. P'SHIP ACT $\S 401(f)$ (1996) (stating that each partner has equal rights in the management and conduct of the partnership).

In contrast, common law municipal self-rule is based on corporate law and draws its legitimacy not from a democratic right of the citizens to autonomous self-governance, but from a delegation of power by a higher sovereign. Our cities, like our corporations, are creatures of statute that exist and have rights (including internal rights to selfgovernance) only to the extent that the state has so granted them. Even our states derive their historical legitimacy from above: an act of the King granting corporate status in the older ones, or an enabling act of the United States Congress for most of the newer ones (Vermont and Texas may be exceptions, more democratically tracing their origins to an act of their inhabitants instead of permission from a sovereign). For attempts to understand municipal law in a more democratic context, see generally Frank I. Michelman, Foreword: Traces of Self-Government, 100 HARV. L. REv. 4 (1986).

Unlike the common law, Jewish law made the connection between partnership and democratic self-rule explicit: the law of municipal self-rule (which was relatively democratic) was derived from the law of partnerships rather than the law of kings. See, e.g., Menachem Elon, I JeWISh LaW: History, SOURCES, PRINCIPLES 55-57 (Bernard Auerbach \& Melvin J. Sykes trans., Jewish Publ'n Soc'y 1994) (1988) (describing the extent of the king's prerogative). The Jewish law of partnerships (and of the selfgoverning kahal, or community), like the UPA, specifies largely procedure - how decisions are to be made. E.g., Rashi, Responsa 247, in 1 THE JEWISH POLITICAL TRADITION 397-98 (Michael Walzer et al. eds., 2000) (discussing the ability of the majority to bind the minority). In contrast, the Jewish law of kings is normative: it specifies the relatively narrow - limits of the king's authority. ELON, supra, at 55-57. Kings, while requiring the consent of the people in some limited sense, derive their authority and their law derives its legitimacy from fulfilling their function as specified in the normative rules of Torah. Id. 
it. $)^{7}$

In contrast, most non-democratic governmental forms are based on notions of trusteeship or exploitation. In trusteeships, the populations are not members but protected wards. Legitimacy and claimed authority are fundamentally based on the governors' claimed ability to fulfill their designated task; if consent of the governed is a value at all (as it was, for example in many medieval theories) it is as evidence that the governor is fulfilling its protective responsibilities and not simply exploiting. Thus, traditional (constitutional or legitimate) monarchies based their right to rule not so much on the people's consent as on the king's protection of them. ${ }^{8}$ Modern military dictatorships claim to be protecting the population from internal or external disorder. Communist regimes purport to be acting in the interests of the workers. Some religious regimes act in the interests of the faithful and in pursuit of a religious ideal: assuring the population's salvation. In each of these non-democratic governments the government claims to be acting on behalf of the population, but it fulfills its task without consulting the citizenry or even seeing any need to do so: were the population to disagree with the government, it would simply demonstrate the population's ignorance, not the state's illegitimacy. ${ }^{9}$

7. Martha C. Nussbaum, Patriotism and Cosmopolitanism, in FOR LOVE OF COUNTRY 2, 5-6, 15, 17 (Joshua Cohen ed., 1996) (arguing that "put[ting] right before country and universal reason before symbols of national belonging" can enrich the consciousness of a cosmopolitan, and noting that "citizen[s] of the world" refuse to be defined by group memberships and local origins, engage in an open dialog, and recognize the humanity in others); see also Amy Gutmann, The Challenge of Multiculturalism in Political Ethics, 22 PHIL. \& PUB. AFF. 171, 193-97 (1993) (proposing that people can reach reasonable universal solutions to many social justice issues despite multicultural differences). This broader sense of membership can motivate people to act decently when narrower loyalties suggest otherwise. See, e.g., Dorothy E. Roberts, Sources of Commitment to Social Justice, 4 RoGER WILliams U. L. REv. 175, 196-98, 200-02 (1998).

8. Hobbes's Leviathan defends absolute rule in these terms; so do many medieval versions of the divine right of kings. THOMAS HOBBES, LEVIATHAN, 223-28 (pt. II, ch. XVII) (C.B. MacPherson ed., Penguin Books Ltd. 1985) (1651). Hobbes is often regarded as the foundation of modern liberalism because he founds the state in the interests of its citizens - but, characteristically of trustee regimes, he sees no need to allow the citizens to define that interest. Id. at 251-61 (pt. II, ch. XX). Similarly, Edmund Burke states that the "power [of kings] has no rational end than that of the general advantage," but insists that that end can be achieved only by making the king "perfectly irresponsible" and praises the English for choosing to view themselves as having no choice, instead "considering our liberties in the light of an inheritance." ED. MUND BURKE, Reflections on the Revolution in France, in III WRITINGS AND SPEECHES OF EDMUND BURKE 231, 266-76 (Little Brown \& Co. 1901) (1790).

9. In different vocabularies one might refer to the trusteeship regimes as messianic regimes, or teleological ones: they answer to an ideal they seek to achieve rather than to consent of those they govern, and thus, in the distinction I make below, are centrally not aggregative but normative. 
The trusteeship view of government is roughly analogous to corporate management's relationship with its shareholders. In the dominant view, public corporations ought to act in the interests of their shares, without offering shareholders a political forum in which to debate what those interests might be and, indeed, even if shareholders (who often are more saliently related to the firm in other roles) might prefer to do otherwise. Shareholders have no right to make business decisions or even to set the most significant goals of the firm. ${ }^{10}$

Similarly, the trusteeship regimes contend that the expert directors-the Party, the Ayatollah, or the General-know better than the beneficiaries how to run the enterprise. And like corporations (but unlike partnerships), the trusteeships impute interests to their beneficiaries (the Nation or the Shareholders): there is no mechanism for political consideration of conflicting claims or alternative goals.

In contrast, exploitation regimes do not claim to be acting in the interests of their subjects. Rather, they are based on the authority of force and conquest. The out-group, whether a national minority or the entire population, is ruled as subjects pure and simple. Claimed legitimacy is based on rights granted by a higher power or on the "right" of force alone. Thus, the regime may claim (as some Romans and American slaveholders did) that the subjects forfeited their lives (and a fortiori, freedom) in war and thus may be held as the sovereign's (or sovereign group's) property. ${ }^{11}$ Claimed legitimacy may be founded in brute force, as in that version of the Jewish legitimacy myth in which God holds Mt. Sinai over the people's heads until they agree to accept the Torah, or the medieval views that founded legitimacy in necessity. ${ }^{12}$ Or it may be formed by grant from such a force-

10. For a discussion of the roles of shareholders and managers, see Daniel J.H. Greenwood, Fictional Shareholders: For Whom are Corporate Managers Trustees, Revisited, 69 S. CAL. L. REV. 1021, 1025-27 (1996) [hereinafter Greenwood, Fictional Shareholders] (contending that managers manage according to a legally constructed goal of profit maximization, not according to the interests of the actual shareholders), and Daniel J.H. Greenwood, Essential Speech: Why Corporate Speech is not Free, 83 Iowa L. REv. 995, 1002 (1998) [hereinafter Greenwood, Essential Speech] (noting that "corporate speech reflects the hypothetical interests of a creature given reality by the market and the law: the fictional shareholder").

11. See, e.g., HOBBES, supra note 8, at 223-28 (pt. II, ch. XVII) (describing a "commonwealth by acquisition" as one founded in "natural force," for example, where the sovereign "by [war] subdueth his enemies to his will, giving them their lives on that condition"); Isaac Abravanel, Commentary on the Pentateuch, Deuteronomy 29, in JEWISH POLITICAL TRAdition, supra note 6, at 37, 39 (stating that God has the right to rule the Jews because he redeemed them from Pharoah: from slavery to slavery).

12. The Biblical story of God giving the law at Sinai is often read as the prototype of a government founded in voluntary consent and covenant. See, e.g., BABYLONIAN TALMUD, Avodah Zarah $2 b$ (explaining that God offered the Torah law to various nations and only the Jews accepted it). However, an alternative version bases God's right 
based authority, as by descent from a Conqueror or as in Burke's picture of illegitimate origins softened by the passage of time. ${ }^{13}$

In each of these exploitation stories, subjects are not the owners but the owned. They are merely inputs to be exploited for the benefit of the ruling group, class or nation; entitled to consideration only to the extent that it is in the ruler's interest to give it to them.

This again is a corporate rather than a partnership model, similar to the relationship of a corporation to its employees. In both the corporation and the exploitation regime it may often be useful to give the employees (or subjects) a stake or an appearance of a stake, in order to motivate them to work for the good of the enterprise. Exploitation regimes often point to the benefits an empire or monarchy provides to its subjects: the Pax Romana, the mission civilatrice, the White Man's Burden. ${ }^{14}$ But when the time comes to divide the pie, the enterprise turns out to view the employees (or subjects) as a cost, separate from itself. Whatever is paid out in wages reduces profits in a corporation. In an exploitation regime, all that goes to the subject or minority group (or employees) is lost to the ruling class or dominant race (or corporation). The contrast to the democratic or partner-

to rule not in consent but in force. This midrash reads "under the mountain" in Exodus 19:17 (usually translated metaphorically as "at the foot of the mountain") literally to mean that while asking the people whether they would accept the law, God held Mount Sinai over their heads, threatening to bury them if they did not accept. BABYLONIan TALMUd, Shabbat 88a; $c f$. Judah Loew, Tiferet Yisrael, ch. 32, in JEWISH PO. LITICAL TRADITION, supra note 6 , at 42 (contending that God held the mountain over the people's heads in order to eliminate any possibility that they might think they had the option of rejecting the Torah).

The Shabbat 88a story converts a covenant of equals, binding because of the consent of the governed, into a classic positivist model of law as authority, where the covenant is simply an acknowledgment of the irresistible violence of the lawgiver. See BABYLONIAN TALMUD, Shabbat 88a. In the view of this story, the law is binding because of its author's power, and consent is no more than a recognition of that authority - legitimacy stems from force, not consent, and the people have no part or legitimate role in law making whatsoever.

Forty years exile in the desert, similarly, could be understood to emphasize that the law binds by inheritance, not consent or adoption: law, like a culture, takes at least a full generation to become our own. For further discussion, see MICHAEL WALZER, ExoDUS AND REVOLUTION 83-90 (1985). The central justification for Torah law offered by the Exodus story in Exodus 20:2- "I am the Lord your God who brought you forth from Egypt" - can, of course, be read to support any of these theories. Id. at 85. It could be either a persuasive justification for agreeing to the covenant, along the lines of "support the Candidate with a record of service," or an illustration of the power of the Lord, demonstrating the futility of resistance. See generally DAVID HALIVNI, Midrash, MishnaH aNd GEMARa: THE JEWISH PREDICTION FOR JUSTIFIED LAW 7-10 (1986) (emphasizing the importance in Jewish law of providing justifications for rules).

13. See BURKE, supra note 8, at 274-75.

14. See generally The Columbia EnCYClopedia 416, 994, 2090, 2349-50, 1480 (Barbara A. Chernon \& George A Vallasi eds., 5th ed. 1993) [hereinafter ColumBIA ENCYCLOPEDIA]. 
ship model could not be stronger: partnership draws, like benefits to democratic citizens, are profits, not costs.

In all the various forms of trusteeship and exploitation regimes, the collective good may be controversial: the good of the nation or the state need not be obvious or agreed-upon. But it is not to be found by asking the subjects, any more than a publicly held corporation could determine its goals by consulting its rank and file employees or the actual human shareholders. Rather, in a trustee regime, some form of elite-political, philosophical, or religious-will debate and decide the issue for the population. In an exploitation regime, the ruler or dominant class, nation, or race will decide in its own interests without independent concern for the subjects. ${ }^{15}$

In contrast, in democracies as in partnerships, these distinctions between the collective enterprise and its participants are improper. Partners are certainly inputs to the firm, like employees. But they are also the firm itself; benefits to them are not costs to the firm. Similarly, citizens are expected and required to contribute to the common enterprise, but the good of the citizenry is the good of the democracy. The government in a democracy must take the good of the people as its own: they are partners, co-owners of the enterprise, not contracting opposites to be given as little as possible in an armslength negotiation. The first defining characteristic of a democracy is that it is government for the sake of "us," not an ideal or another group.

\section{The Teleology of Democracy and its Competitors}

A democracy has no goal or interest apart from the self-defined goals of its citizenry. This does not mean that a democracy is necessarily valueless, neutral or uncommitted. Some may be: the ideal of our First Amendment points in that direction, towards a liberal state floating above and separate from the commitments of its citizens, creating an open forum in which private citizens debate, discuss and define as individuals without collective intervention or resolution. ${ }^{16}$ In such a liberal democracy, the state honors individual visions by taking none of them as its own.

But democracies need not be liberal in that sense: when citizens are deeply committed to particular visions of the good life, specific

15. Naturally it will often be in the best interest of the rulers to consider the interests of the ruled, just as it is typically in the interest of shareholders to consider the interests of corporate employees. But this is a contingent, empirical analysis, not a necessary one. The interests of the partners (people) are by definition the interests of the partnership (democracy); the interests of employees (subjects) have no value except when and to the extent that pursuing them is in the interests of shareholders (the ruling class).

16. See U.S. CoNST. amend. I. 
cultural heritages, or understandings of justice or morality, they may seek to have those visions and commitments supported and fostered by the government. While that may be, in some forms, un-American, it is not un-democratic. On the contrary, the continuing efforts to create, maintain, change, and challenge a collective identity surely are a legitimate and common subject of democratic politics. A committed state can still be a democratic one in my sense. France's commitment to French culture or Greece's to Greek culture are not liberal, but so long as they are endorsed and defined by the majority of the French or Greek citizens in an open politics, they are democratic.

The commitment of a democratic state, however, must come from the commitments of its citizens. The state's ideals must remain grounded in the citizenry, and it remains legitimate only so long as it takes its guidance from below rather than the other way around. Accordingly, committed democracies remain distinctly democratic only so long as their commitments stem from an ongoing and open politics in which each citizen is a full member.

In any real community, the goals and commitments of individuals will both conflict and change. Necessarily, then, the state's commitments, if any, also will be both controversial and timebound. For this reason, while democracies (and partnerships) can delegate rule to representatives, full rule by the experts in the corporate style is impossible. The partners must first set the goals before experts can try to implement them-and in a dynamic polynomic world, the setting of the goals is an ongoing controversy, not a past moment to be interpreted. Democracies are polynomic systems, in which multiple values conflict, and conflict requires debate, struggle and compromise before expertise has any place.

So a second defining characteristic is that a democracy has no telos except to the extent that its citizenry does. Given the multiplicity of individual ends, a democracy cannot have any unified, eternal or overarching value against which all its actions can be tested, other than the enterprise of promoting its citizens' values as they are or can convince each other they should be.

Other forms of government, in contrast, may express different norms. A republic could be dedicated to a specific view of virtue, culture or religion, as in Khomeni's Iran or ancient Sparta. Theocracies (including the atheist varieties) can be controlled by law (or a historic Mission) that is understood as unchanging or independent of the will of the faithful. Nationalist states may be populist and even popularly controlled without being democratic in my sense: they take as their goal the imputed interests of a collective nation, without necessarily giving full (or any) weight to the views of some (or all) the inhabitants of the state. But even non-liberal democracies can have no fixed teleology: they have no separate existence from their multifarious 
citizens.

I contend, then, that democracy requires some mechanism for the citizenry to participate in a never-ending process of setting goals and mediating value conflicts. Any attempt to end that debate is anti-democratic: a move towards a trusteeship, in which given or set values can be explicated and applied by mandarin experts without any need for popular participation. Thus, in our context, claims that the Founding Fathers decided some issue for us-that we are foreclosed from changing their minds-are profoundly anti-democratic. Democracy as partnership excludes any theory of constitutional adjudication that assumes that fundamental value decisions were made at some distant point in the past and now can be elucidated without reference to the beliefs and desires of the current citizens or without convincing them to set aside those beliefs or interests. That kind of apotheosis of the Founders elevates an ideal or telos above the actual people who compose our democracy, suggesting that the government is for the Founding Fathers (or their goals), rather than for us. ${ }^{17}$

\section{Equality of Membership in Democracy as Partnership}

In democracies, as in default-rule partnerships, ${ }^{18}$ each citizen is equally a member. Only if we are equally members can we claim that the state reflects the values of each of us or that it is a common enterprise both of and for the citizenry.

To be a partner in the enterprise means that the enterprise must take the partners' goals and good as its own, and that the partner must always be an end of the enterprise and not merely a means. No member should be seen as merely a tool to other members' ends: to be only a tool or a means is to be denied the status of principal in the enterprise. Just as a partner is a principal of the enterprise (and an agent as well) ${ }^{19}$ citizens of a democracy also must be treated as ends of the enterprise-even when they are, as they always will be, its most important tool..$^{20}$

17. Of course, citizens in a democracy may - and surely should - accept arguments urging them to exercise their sovereignty in specific ways and condemning them if they do not; most values-based arguments do that. There is nothing anti-democratic about a constitutional theory that tells the citizenry they ought to set aside their own beliefs or interests and follow the whims or wisdom of the Founding Fathers - provided that it does not purport to allow the government to impose this vision on us regardless of our own views.

18. UNIF. P'SHIP ACT § 18(e) (1914); REVISED UNIF. P'SHIP ACT § 401(f) (1996) (stating that partners have equal rights in management of partnership).

19. UNIF. P'SHIP ACT \& 15 (1914); REVISED UNIF. P'SHIP ACT § 306 (1996) (stating that partners are liable for partnership obligations); UNIF. PARTNERSHIP ACT $\S 9$ (1914); REVISED UNIF. P'SHIP ACT § 301 (1996) (stating that partners are agents of the partnership).

20. I mean only to be describing the minimal claim that I see as inherent in the 
Thus, the concept of democracy as membership requires that no member be treated unfairly as a tool for some end of which he or she is not a part and that no member be deprived of an equal say in setting collective ends. More powerfully, equal membership demands a strong form of mutual identification: we, collectively, must take the ends of each of us, individually, as our own.

The understanding of equality of membership I have outlined can be sharply distinguished from stronger theories of distributive egalitarianism. ${ }^{21}$ Although equality of membership can be understood as foundational to distributional egalitarianisms, I believe equality of membership is based on more limited and less controversial premises than many classical egalitarian theories. At the same time, it demands both less and more than the more familiar theories: distribution alone may be neither necessary nor sufficient to satisfy its demand of mutual concern.

The egalitarian distribution theories insist that, at least in the first instance, equality of "respect" or "humanity" entitles individuals to equal distributions of assets, ${ }^{22}$ primary goods, ${ }^{23}$ economic starting points, ${ }^{24}$ or happiness. ${ }^{25}$ Of course, most theorists then propose circumstances under which such equality might be abandoned, usually on the ground that all (or each) would be made better off by doing so. ${ }^{26}$ The equal voice principle I invoke seems far less controversial.

concept of democracy. My version is somewhat weaker than Rawls's Kantian understanding in Theory of Justice, since in my view democracy, like partnership, clearly does allow citizens to be treated as means (agents), so long as they are also ends (principals). See RAWLS, supra note 2, at 179-80 (arguing that the design of a social system under a Kantian interpretation requires that people not be treated as a means, but only as ends).

21. The discussion that follows brutally oversimplifies complex and important theories. My glib treatment is excusable, if at all, only by my attempt not to transform this Article into a literature survey or textual analysis. Sympathetic readers will note the influence of these and other theorists, footnoted and not, on every line of this article.

22. See Isaiah Berlin, Equality, 56 Proc. OF THE ARISTOTELIAN Soc'Y 301, 315-17 (1956) (noting that "all human beings start off with equal rights to acquire and hold property").

23. See, e.g., RAWLS, supra note 2 , at 91-92 (creating an original position of equality in order to allocate primary goods).

24. See, e.g., Nozick, supra note 6 , at $11,118,161,301$ (justifying inequality to the extent that it results from fair transactions from a position of initial equality); BRUCE ACKERMAN \& ANNE ALSTOTT, THE STAKEHOLDER SOCIETY 3-5 (1999) (advocating that each citizen should receive an initial allocation of $\$ 80,000$ upon reaching majority).

25. See, e.g., JEREMY BENTHAM, AN INTRODUCTION TO THE PRINCIPLES OF MORALS AND LEGISLATION 1-2 (1970) (arguing that behavior is governed by pain and pleasure); HENRY Sidgwick, THE METHODS OF ETHICS 408-09 (bk. IV, ch. 1, § 2) (3d ed. 1884) (basing utilitarian theory on the assumption that each individual is equally entitled to pleasure or happiness).

26. Hobbes, thus, argues that men will sacrifice their initial equality to gain a 
Each of these distributive egalitarian theories is a development of Aristotle's principle that justice consists in treating equals equally. ${ }^{27}$ Egalitarians generally invoke some factor in which they think all humans are equal: equally entitled to respect, ${ }^{28}$ equally human, ${ }^{29}$ equally able to articulate reason, ${ }^{30}$ equally able to feel pleasure and pain ${ }^{31}$ or equally able to kill each other. ${ }^{32}$ But these ritual beginnings seem insufficient. The quasi-empirical premise is false on most understandings-Eichmann and Beethoven are not entitled to equal respect, different people have different capacities for pleasure and pain, ${ }^{33}$ the distinction between humans and other animals seems artificial and tautological ${ }^{34}$ or if taken seriously distinguishes among humans as well, ${ }^{35}$ and reasoning or questioning ability is quite variable and missing entirely in infants. ${ }^{36}$

But if the premise of equality is invalid, the Aristotelian principle leads-as Aristotle himself thought-to a defense of aristocracy, not egalitarianism. ${ }^{37}$ It is as unjust to treat unequals equally as it is to treat equals unequally. So as a matter of logic the egalitarian theories often seem no stronger than their premises, which seem weaker than the conclusions.

The Aristotelian principle leads to more democratic results if the equality we share is equality of membership in a common enterprise-principally the state, but in a weaker sense, the human project. Equality of membership means that the collective enterprise ought to consider the good of each member as its own good. The collective, under this view, ought to see each member's good as a collective good, each member's bad as a collective bad. This "partnership

more secure life. HOBBES, supra note 8, at 183. Rawls formalizes the idea in his "difference principle." RAWLS, supra note 2, at 75-78.

27. See, e.g., Berlin, supra note 22 , at 322 n.6.

28. See, e.g., RAWLS, supra note 2, at 337 (expressing the Kantian view of a natural "duty of mutual aid" among equals).

29. See, e.g., Berlin, supra note 22 , at 301-02.

30. See, e.g., Bruce A. ACKERMan, Social Justice in the Liberal State 80 (1980) [hereinafter ACKERMAN, SOCIAL JUSTICE IN THE LIBERAL STATE] (basing citizenship status and basic rights on the ability to argue).

31. See, e.g., BENTHAM, supra note 25, at 1; SIDGWICK, supra note 25, at 497 (bk. IV, concluding ch., § 3 ).

32. See, e.g., HOBBES, supra note 8, at 183 (pt. I, ch. 13).

33. John StUart Mill, Utilitarianism 16-20 (ch. 2) (Prometheus Books 1987) (1863) (explaining that Socrates has more - or at least different - capacities for pleasure than pig).

34. See, e.g., SIDGWICK, supra note 25 , at 408-09 (bk. IV, ch 1, § 2).

35. See, e.g., MILL, supra note 33, at 24-27 (ch. 2).

36. See, e.g., ACKERMAN, SOCIAL JUSTICE IN THE LIBERAL STATE, supra note 30, at 109 (explaining that infants lacking reasoning ability are not citizens).

37. See, e.g., Berlin, supra note 22, at 322 n.6 (describing the Aristotelian principle). 
principle" underlies each of the distributive egalitarianisms and gives them much of their force, it seems to me, although it is not equivalent to any one of them: they share a core of seeking to express the commonness of our common enterprise, our joint membership, while differing in their understandings of in what membership consists. $^{38}$

In democracy as equal membership, the Aristotelian principle that equals should be treated equally (and unequals unequally) applies straightforwardly. All the citizens are equally members, each entitled to be treated as an end, not merely a means, of the state. They are not likely to be equal in abilities, talents, skills, moral worth, connections, nobility, or even common decency: but they are equally members and therefore entitled to equal membership. In what equal membership consists is a more difficult issue, but, at a minimum, it should include both a say in setting the goals of the enterprise and mutual recognition-of each member with respect to each member-that the joint enterprise is for mutual benefit. "All for one and one for all." ${ }^{\text {39 }}$

Distributive egalitarianism is neither necessary nor sufficient in a system of full membership. I take it that the various egalitarian theories are controversial precisely because they each capture parts, but only parts, of the fuller concern that commonality, fully understood, would demand. Since what we are equal in is only membership, the Aristotelian Principle does not demand Rawls' difference principle, let alone stronger egalitarianisms, so long as material wealth differences do not translate into membership differences (and it demands more than the difference principle if they do..$^{40}$

38. See, e.g., RAWLS, supra note 2, at 27-33 (describing Kantian theory and its relationship to utilitarianism).

39. See, e.g., AleXandre Dumas, The Three Musketeers (Eleanor Hochman trans., Penguin Books Ltd. 1991) (1844).

40. The test is whether income inequality leads to membership inequality. See MICHAEl Walzer, Spheres of Justice: A Defense of PluRalism AND Equality 63 (1983) [hereinafter WALZER, SPHERES OF JUSTICE] (arguing that membership rights are necessary for distributive justice). It seems likely that the serious increase in income and especially wealth inequality over the last couple of decades is a serious threat to American democracy. The share of the national wealth held by the richest $1 \%$ more than doubled between 1976 and 1998. Edward N. Wolff, Recent Trends in Wealth Ownership, 1983-1998, Working Paper No. 300, $\$$ 6-8, tbls. 1-2, 6, 15 (2000), available at http: / / www.levy.org (last visited July 22,2001 ) (showing $56 \%$ of the total growth in financial wealth from 1983 to 1998 went to the top $1 \%$, those with net worth exceeding $\$ 3,335,000$ in 1998 ; the top $1 \%$ held $47.3 \%$ of financial wealth in 1998 , up from $42.9 \%$ in 1983 , and almost $80 \%$ of that was held by the top half of the top $1 \%$; the number of deca-millionaires almost quadrupled, while the percentage of households with less than $\$ 10,000$ net worth (in 1995 dollars) held steady at about $30 \%$ ); EDWARD N. WOLFF, TOP HEAVY $67 \&$ n.22 (1995) (in 1976, the share of the top 1\% constituted only $20 \%$ of financial wealth); Paul Krugman, The Right, the Rich and the Facts; Decon- 
On the other hand, distributive equality may not be enough. When each member is an end of the collective enterprise, sometimes it is necessary to go beyond equality to principles of friendship or family-to concern rather than disinterestedness-which call for more or less than egalitarianism. But in most cases, each of the theories of distributive egalitarianism calls for greater mutual concern than we often see in ordinary politics. And that, I propose, suggests that the leading theories of justice each tap into a common source: a view that democratic societies are like partnerships of their citizens.

\section{Implementing Democratic Equality}

Democracy, then, is an attempt to express a belief that we-all citizens-are in a common enterprise, in which we each should treat each of us as one of us. It is the notion that the state is a partnership of all its citizens: we are suppliers of inputs to the enterprise, recipients of its output, and the enterprise itself. Citizens are the ends of the state as well as its means, but as co-owners or partners they should never be mere inputs to be exploited, competitors whose gain is seen as the enterprise's loss, or beneficiaries whose best interests stand separate from their perceived interests. The enterprise should direct itself to promoting the good of each of us.

While the principle is simple, its implementation is difficult. A corporation views payments to its employees as an expense: by doing so, it affirms that employees are not members. Democratic states must do otherwise. But if this limitation condemns the worst abuses-Jim Crow and other forms of exploitation or second-class citizenship—it hardly mandates any particular positive program. ${ }^{41}$

The positive content of equal membership is a central subject for political debate and likely to be controversial. Some will view the rights, obligations, and privileges of membership as minimal, if perhaps not as minimal as the Supreme Court did in defining the privileges and immunities of American citizenship for the freed slaves in the Slaughterhouse Cases.$^{42}$ Others will take a thicker view, requiring

structing the Income Distribution Debate, AMERICAN Prospect No. 11, at 19 (Fall 1992) (suggesting that most of the growth of last two decades has gone to the rich, especially the top $1 \%$ and above); cf. Wealth Explodes at the Top, BUSINESS WEEK, July 31,2000 , at 34 . Inequality itself creates the potential for winners to convert their success into material wealth that destroys the foundations of democracy as partnership. See discussion infra Part II.B; see also WALZER, SPHERES OF JUSTICE, supra, at 61-63.

41. Cf. Dred Scott v. Sanford, 60 U.S. (19 How.) 393 (1856). Justice Taney concluded that African-Americans were not citizens because no citizen could be treated the way that America treated even free African-Americans. Id. at 451. This much of his reasoning is correct: a citizen cannot be treated as a mere tool to the happiness of others. What follows, however, from a finding that we are treating fellow Americans improperly should be reform, not further exclusion.

42. 83 U.S. (16 Wall.) 36,76 (1873). 
that a common enterprise as broad as a state encompass and respect all the aspects of the citizens' joint and several personalities. Those debates are closely linked to, and cannot be resolved independent of, the debate the members must have over the scope of the common enterprise and its goals. The equal membership principle demands that each member have equal voice in that controversy. It does not demand any particular resolution.

Each of us is a means to the happiness and other ends of others: the principle should not be understood to encourage some kind of aspiration to isolated self-sufficiency. Similarly, the collective good (or more likely goods) will be controversial and often impossible to achieve ${ }^{43}$ Our goods may be individualistic or private, in the sense that each us can be imagined to achieve what is good for us independently of others. Or not: one could argue (with Hannah Arendt) that the public space is all-important, so that individual good is only achievable without a strong collective concept. ${ }^{44} \mathrm{I}$ do not mean to step into that difficult debate.

Furthermore, the collective can-indeed must-recognize that different individuals have different and often conflicting needs, desires, and goals (moreover, that even single individuals have differing and conflicting needs, desires, and goals). In a full democracy, we will take each other's ends as our own, but that alone is not enough to resolve the contradictions among those ends (any more than selfinterest alone is enough to resolve the contradictions among our own individual ends).

In short, democracy as partnership is broad enough to encompass most communitarians and libertarians, utilitarians and Kantians, Rawlsians and egalitarians. But it cannot accommodate strong nationalisms that would limit membership in the democracy to members of the nation (understood as different from the population of the state), nor cultural nationalisms that see the state as promoting a set of cultural or religious values that (even if ratified by the people) bind the state outside and beyond them, nor secular or religious theories of false consciousness that contend that a single good applies to all.

43. See, e.g., Jean-Jacques Rousseau, The Soclal Contract and Discourses 213-17 (bk. II, ch. 7), 265-68 (bk. III ch. 15) (G.D.H. Cole trans., J.M. Dent \& Sons Ltd. 1973) (1762) [hereinafter ROUSSEAU, Social CONTRACT] (explaining the disadvantages of governmental forms and noting that "the moment a people allows itself to be represented, it is no longer free"); JEAN-JACQUES ROUSSEAU, THE GOVERNMENT OF POLAND $5-9,18,30$ (Willmoore Kendall, trans., Bobbs-Merrill Co. 1972) (1835) (contending that freedom requires that the legislator transform individuals so that they see their individual good as inseparable from the collective good - and suggesting that this freedom is likely to be rare indeed).

44. Hannah Arendt, What is Freedom, in BETWEEN PAST AND FutURE: Eight EXERCISES IN POLITICAL THOUGHT 154-55 (1968). 
Even mass support would not turn Khomeni's Iran into a partnership. In a democracy, members are not employees, nor agents (even of God or History), nor factors of production. Rather, citizens, not God or the National Mission, are the owners of the enterprise. This does not mean that citizens may not view themselves or their co-religionists or co-movementists as tools of a greater mission or means to God's ends. It only means that once a state is harnessed to such goals independent of the current views of its citizens, it is no longer a democracy. This theory, then, shares the anti-capture understanding of the liberal state: a democratic state must be able to change its commitments as its citizens do. But democracy as partnership goes further: the state must have some mechanism for acknowledging that its citizens' commitments differ at any point in time and not merely across time.

The fundamental claim of democracy is that the state must belong to all of us, in the sense that it (and we) must treat the good (or needs, or goals) of each (or all) of us as its goal. Accordingly, a democratic state should never treat any of its citizens as mere tools towards someone else's goals. Membership means that no citizen should ever be seen as a competitor in a self-regarding game: the citizen is part of the state, not competing with it.

But democracies attempting to realize the equal membership ideal face a basic problem. None of the four leading governance mechanisms we have can, by itself, meet this need. Each, taken individually, has major flaws. I examine their strengths and especially their weaknesses seriatim.

\section{B. Democracy, Majoritarianism, and its Problems}

Majoritarian representation, the most familiar aggregative system, uses voting and legislation to summarize (and sometimes to transform) the views of the various participants. Participants use discussion, rhetoric, organization, coalition building, persuasion, and generally politics to attempt to convince each other of the merits of positions-as they do in each of the systems I discuss. The distinction of majoritarianism is that in the end, decisions are made on a basis of one person, one vote (or one representative, one vote), and a majority rule for each particular decision.

\section{The Majoritarian Difficulty}

The characteristic problem of the modern democratic system is that majority rule is not necessarily particularly fair. Indeed, odd as it may seem at first glance, majority rule is not always compatible with the partnership ideal. The point of democracy is to make clear that we are all (equally) together in a common enterprise. Ideally, it should endorse procedures that ensure that we should all benefit 
(equally) from the common enterprise. Majority rule does not do so clearly. ${ }^{45}$

\section{a. The Winner-Take-All Problem}

All other things being equal, a majority ought to prevail over a minority on any given issue. The alternative, after all, is that the minority prevails, and that makes no sense at all. On the other hand, when a majority wins, even if by only a small margin, usually it wins the whole issue or even a whole set of issues.

And when the same majority repeatedly wins over a range of issues, what seemed obviously right becomes obviously wrong. Fairness, at least absent some special consideration, seems to require that a group of $51 \%$ get about $51 \%$ of the victories, $51 \%$ of the goods, $51 \%$ of the turns, win on $51 \%$ of the issues and so on. If a $51 \%$ majority gets $100 \%$ of the goods, majority rule violates this proportionality between the margin of victory and the result, or between the size of the group and its social weight.

Critically, the mere fact that the majority is a majority is not enough to justify departing from proportionality. One could argue that those who contribute more, or need more, or deserve more should get more, but it is hard to make any coherent argument for why those who are slightly larger in number, simply by that fact alone, should get anything more than a slightly larger share. A majority that uses its power to take a disproportionate share is using the minority as a means to the majority's ends-exploiting them rather than cooperating with them as partners. I will refer to this problem of majority overreaching by the familiar terms "majority tyranny" or the "winner-take-all problem."

The Athenian democrats famously rejected majoritarian election on the ground that it violates equal citizenship. ${ }^{47}$ Fairness, in their

45. See Daniel J.H. Greenwood, Akhnai, 1997 UTAH L. REv. 309, 333-45 (1997) [hereinafter Greenwood, Akhnai].

46. $C f$. ROBERT H. FRANK \& PHILIP J. COOK, THE WINNER-TAKE-All SOCIETY 1-20, 124-46 (Penguin Books Ltd. 1996) (1995) (employing a usage not identical to the author's). Frank emphasizes the threat that networking efficiencies, new methods of delivery of services and broader markets will create a small class of superstars, leaving little economic function (or reward) for the runners-up: why go to the second best if the best is just as available? Id. at 124-46. The power of Frank's analysis is that marginal differences in an input - the difference between a winner and a runner-up in an Olympic sport - can translate into disproportionate differences in the gains - massive endorsement deals and world fame for the winner and oblivion for the runner-up. The winner-take-all problem in majoritarianism is similarly one of disproportion, if not necessarily as extreme. Here, too, the winners of elections can take a disproportionate share of political goods (whether economic or not).

47. See, e.g., Charles louis de Secondat, Baron de la Brede et de MontesQUIEU, THE SPIRIT OF LAWS 107-12 (bk. II, ch. 2) (Thomas Nugent trans., David Wal- 
view, requires an equal chance of serving; they selected representative officials by lot (as we do, at least to some degree, in jury selection $^{48}$ and the military draft). Using lottery rather than popularity as a selection mechanism is a way of emphasizing the equality of the participants, especially in light of the obvious problems of competence and efficiency it raises. In more complex organizations, we may reject lottery (and even popularity) as selection mechanisms for reasons of competence or efficiency. But the Athenian concern remains: mere support of the majority, without more, is no justification for taking an unfair share.

Similarly, in our business law-where well-funded representatives of different interests have both the incentive and opportunity to debate and negotiate deals they perceive as fair-we reject the idea that a majority or their representatives can do whatever they want. In partnerships, the basic rule is unanimity (much as in classic social contract theory, in which fundamental rights are determined by a hypothetical agreement to which all rational citizens could be imagined to have agreed). ${ }^{49}$ Majority rights are sharply constrained by the requirement that all fundamental changes require unanimous consent, ${ }^{50}$ and even more so by the inalienable right of any partner to cause dissolution at any time for any reason, which guarantees that any decision which any partner views as highly significant must be unanimous. ${ }^{51}$

Corporate law uses fiduciary duties to achieve similar limitations on majoritarianism. ${ }^{52}$ Voting majorities of the corporation have no right to change the fundamental corporate goals or norms. ${ }^{53} \mathrm{~A}$ vot-

lace Carrithers ed., Univ. of Cal. Press 1977) (1748) ("The suffrage by lot is natural to democracy; as that by choice is to aristocracy.").

48. Cf. Hernandez v. Texas, 347 U.S. 457, 481-82 (1954) (declaring unconstitutional a Texas discretionary jury system in which commissioners chose those they believed "best qualified" to serve on the venire, resulting in no Spanish-surnamed jurors in the 25 years preceding the suit).

49. See Greenwood, Akhnai, supra note 45, at 333-39.

50. UNIF. P'SHIP ACT $\S 18(h)$ (1914) (requiring unanimity for acts in contravention of the partnership agreement); UNIF. P'SHIP ACT $\S \S 9(3), 18(\mathrm{~g})$ (1914) (requiring unanimity in additional circumstances ).

51. UNIF. P'SHIP ACT $\$ 31$. Robert Wolff concludes that this same rule ought to apply to society generally: only unanimous decisions are legitimate. ROBERT PAUL WOLFF, IN DEFENSE OF ANARCHISM 22-27 (1970) (describing an admittedly unrealistic system of "unanimous direct democracy" under which "every member of the society wills freely every law which is actually passed").

52. See, e.g., Zahn v. Transamerica Corp., 162 F.2d 36, 42-44 (3d Cir. 1947) (holding that majority shareholders were not entitled to enrich themselves at the expense of minority shareholders); Sinclair Oil Corp. v. Levien, 280 A.2d 717, 721-22 (Del. 1971) (holding that a controlling shareholder has fiduciary duties towards the minority).

53. See, e.g., Dodge v. Ford Motor Co., 170 N.W. 668, 684 (Mich. 1919) (determining that the majority shareholder has no right to run a corporation for any purpose 
ing majority cannot decide to allocate corporate funds to itself and not the minority.$^{54}$ Elected board of directors are barred from treating those who voted for it differently from those who voted against: directors have a judicially enforceable fiduciary duty to act in the interests of minority shares just as much as majority ones, and indeed, in the interests of all the shares regardless of the views of the shareholders ${ }^{55}$ Proportionality, in this law, is more fundamental than majoritarianism.

Perhaps most evocative of all, where nothing is at stake but our sense of right and wrong we also reject unbridled majoritarianism. A kindergarten teacher who allocated important positions-class monitor, eraser collector, and so on-by pure election with no rotation principle would clearly be in derogation of duty. We teach kids to take turns-not to act as baboons would (or some aristocrats would have their inferiors do), by deferring to grabbing by the strongest, most popular, or best connected. ${ }^{56}$

More generally, in any common enterprise when decisions cannot be made unanimously, fairness and equal consideration or joint membership seem to call for an allocation based on something like proportional sharing or taking turns: you win some, you lose some, and in the end, everyone comes out with some roughly similar proportion of their needs and desires fulfilled.

Majority rule, on the other hand, is winner-take-all; majoritarian systems can easily violate the fairness or proportionality principle, especially if the majority is readily identifiable and it acts in its own interests rather than the interests of the community as a whole (or

other than share value maximization).

54. MODEL BUS. CORP. ACT $\S$ 6.01(a) (1984) ("All shares of a class must have preferences, limitations, and relative rights identical with those of other shares of the same class ...."). For further discussion, see generally Greenwood, Fictional Shareholders, supra note 10, at 1050-54; Greenwood, Essential Speech, supra note 10, at 1034-37.

55. See, e.g., Wilkes v. Springside Nursing Home, Inc. 353 N.E.2d 657, 664 (Mass. 1976) (finding that the majority may not freeze-out the minority from corporate benefits); Smith v. Van Gorkom, 488 A.2d 858, 893 (Del. 1985) (barring directors from leaving most fundamental of all shareholder decisions - whether to sell the company - to the discretion of the shareholders); Revlon, Inc. v. MacAndrews \& Forbes Holdings, Inc. 506 A.2d 173, 184-85 (Del. 1985) (requiring directors, in an auction contest, to pursue share value maximization, even where many shareholders - who were also bondholders - might have preferred otherwise); Unocal Corp. v. Mesa Petroleum Co., 493 A.2d 946, 958 (Del. 1985) (discussing the limits of directors' obligation to act in "the best interests of [the corporation] and [all] other shareholders"); Paramount Communications, Inc. v. Time Inc., 571 A.2d 1140, 1154-55 (Del. 1989) (demonstrating the irrelevance of share majority views in determining directors' duties).

56. On baboon political behavior, see ROBERT SAPOLSKY, A PRIMATE'S MEMOIR 99 (2001). 
the losers perceive it to be doing so) across a range of issues. ${ }^{57}$

For this reason, most defenses of majoritarian democracy assume away fixed majorities. Majority rule is most attractive when different people will be in the majority on different issues in rapidly shifting pluralist coalitions. ${ }^{58}$ Then, assuming that majority rule is restricted to logrolling, pork barrel, or distributive issues, and that all groups are allowed into the pluralist bargaining game, majority rule by coalition building can be imagined to be likely to result in a rough proportionality rather than winner-take-all.

Rough proportionality is, of course, a difficult problem. Consider the well-known problem of the utility monster: the person whose needs (or desires) are so great that to satisfy even a small portion of them would require most of the available resources. Or to similar effect, consider the difference between two versions of the proportionality principle: "those who do not work, neither shall they eat" vs. "to each according to his needs." Different understandings of proportionality give rise to different-and incompatible-distribution principles. Only a miracle-like manna at Sinai-will make them coincide. ${ }^{59}$ Thus, we are told that each Israelite ate what he or she collected (the work objectively contributed affects desert), that each collected according to his or her other abilities (subjective effort is also relevant), that each gathered according to his or her eating (needs are relevant) and according to his or her desires (manna, on one account, tasted like the food each most wanted). ${ }^{60}$ And then, it also met the criterion of equal division: "when they measured it by the omer, he who gathered much did not have too much, and he who gathered little did not have too little." The Rabbis quite correctly viewed the happy coincidence of all these disparate measures of the correct distribution as a miracle of importance at least equal to the provision of manna itself. ${ }^{62}$

Even were we to agree on a single understanding of proportionality, determining whether it has been met requires examining a pattern of decisions rather than particular ones, an extremely difficult

57. Cf. Richard F. Pildes, The Politics of Race, Chandler Davidson \& Bernard Grofman, Eds., 108 HARV. L. REV. 1359, 1367-76 (1995) (book review) (describing extensive patterns of racially motivated voting resulting in near exclusion of substantial minorities from political process).

58. See, e.g., Robert A. Dahl, A Preface To Democratic Theory 27-30 (1st Phoenix ed. 1963) (1956) (hypothesizing that "[t]he development of majority faction [and resulting tyranny] can be limited if the electorate is numerous, extended and diverse in interests.").

59. Exodus 16 .

60. Id. at 16:16-16:17.

61. Id. at $16: 18$.

62. For further discussion, see Daniel J.H. Greenwood, On Equality (1983) (unpublished essay on file with the author). 
task. The difficulty of defining the notion of proportionality in any careful way in this context probably means that anyone who is inclined to feel exploited will be able to justify doing so, at least to his or her own satisfaction. Conversely, the complacent can justify even particularly greedy grabs as a possible result of political give and take and the compromise necessary to lead to proportionality. ${ }^{63}$

Moreover, fairness is not necessarily the only value at stake. We might want to give up on the proportionality principal because it involves too many meetings or negotiations, ${ }^{64}$ or for the sake of faster economic growth. ${ }^{65}$

Indeed, in a true common enterprise, fairness and proportionality tend to be replaced as principles with friendship. Friends will often give disproportionately, following a different command that is not an equality principle at all-"love your friend as yourself." In a political system such as ours, friendship can best be expressed through voting-but only if voters vote based on the interests of everyone, not just themselves. This is the power behind the notion of "republican virtue" or Rousseau's general will ${ }^{67}$ (at least when those theories are not just a cover for excluding part of the population from the people, converting a nominally democratic regime into an exploitation or trusteeship one). With a sufficiently friendly electorate, majority rule would be a device for reaching a collective decision, but emphatically not a justification for voters' acting self-interestedly.

63. See, e.g., ROBERT DAHL, WHO GOVERNS? DEMOCRACY AND POWER IN AN AMERICAN CITY 314-16 (1961) (finding a rough proportionality); Wards Cove Packing Co. v. Atonio, 490 U.S. 642, 652-54 (1989) (rationalizing a pattern of discrimination as ordinary economics); McCleskey v. Kemp, 481 U.S. 279, 308-09 (1987) (rationalizing a pattern of discrimination as mere correlation); Milliken v. Bradley, 418 U.S. 717, 750-52 (1974) (avoiding the boundary problem in order to rationalize a pattern of discrimination); Swain v. Alabama, 380 U.S. 202, 226-27 (1965) (rationalizing a pattern of discrimination as ordinary courtroom politics); Korematsu v. United States, 323 U.S. 214 223-24 (1944) (rationalizing a pattern of discrimination as necessary); Plessy v. Ferguson, 163 U.S. 537, 549-51 (1896) (rationalizing a pattern of discrimination as ordinary workings of civil society).

64. See, e.g., Michael Walzer, A Day In The Life Of A Socialist Citizen, in ObliGATIONS: ESSAYS ON DISOBEDIENCE, WAR, AND CITIZENSHIP 229, 230 (1970) (stating that socialism requires too many meetings); Henry Hansmann, When Does Worker Ownership Work? ESOPs, Law Firms, Codetermination, and Economic Democracy, 99 YALE L.J. 1749, 1784-85 (1990) (finding that democratic governance mechanisms are more expensive than ownership except where common interests predominate).

65. But see FrANK, supra note 46, at 123 (arguing that under current economic conditions, increased equality would lead to increased economic growth).

66. Leviticus 19:18; cf. JERUSALEM TALMUD, Nedarim 9:4 (recounting dispute between R. Akiva and R. Ben Azzai over whether this is a sufficiently high aspiration: Ben Azzai says that respect for humans made in the image of God requires honoring others even when you might not honor yourself).

67. ROUSSEAU, SOCLAL CONTRACT, supra note 43, at 203-04 (bk. II, ch. 3), 229-34 (bk. IV, ch. 1). 


\section{b. The Might-Does-Not-Make-Right Problem}

Locke began his defense of the majoritarian principle by invoking the greater power of the majority: "it is necessary the body should move that way whither the greater force carries it." ${ }^{68}$ But majority strength alone cannot be enough to justify majority rule. Majorities cannot transform wrong into right.

It is easiest to see that majority approval cannot make injustice into justice when the majority decides to exclude a "discrete and insular minority" from the political community: no one thinks that the apartheid of South Africa was worse than the Jim Crow of Georgia (but not Mississippi) simply because in South Africa and Mississippi but not Georgia whites were a minority. ${ }^{69}$ There may have been other reasons why Jim Crow or apartheid was more or less reprehensible in different jurisdictions, but majority approval surely is not one of them.

But the problem is broader than active discrimination or extreme situations. Majority approval alone does not make an otherwise immoral, unfair, or unjust rule fair or acceptable: it just shows that the majority is immoral or unjust. ${ }^{70}$ Thus, for example, neither side of the abortion debate accepts that even a definitive majoritarian ruling would decide the justice of the issue: a majority voting the wrong way simply shows itself to be wrong. ${ }^{71}$

68. LOCKE, supra note 6 , at 52 ( $\$ 96)$. The entire section illuminates Locke's idea:

For when any number of men have, by the consent of every individual, made a community, they have thereby made that community one body, with a power to act as one body, which is only by the will and determination of the majority: for that which acts any community, being only the consent of the individuals of it, and it being necessary to that which is one body to move one way; it is necessary the body should move that way whither the greater force carries it, which is the consent of the majority: or else it is impossible it should act or continue one body, one community, which the consent of every individual that united into it, agreed that it should; and so every one is bound by that consent to be concluded by the majority.

Id. (emphasis omitted).

69. Mississippi had a African-American majority in each census from 1840 until 1930. HistoriCAL STATISTICS OF THE UNITED STATES, U.S. DEP'T OF COMMERCE, BUREAU OF THE CENSUS 30 (Series A 195-209) (1975). In Georgia, during the same period, African-Americans were a minority. Id. at 26.

70. The most famous example in the Christian West no doubt is the alleged approval by "the Jews" of the Roman execution of Jesus as a Jewish pretender to the throne of an independent Jewish state (messiah). In many Christian traditions, this became a justification for condemning all Jews; no one took the alleged majority approval as enough to justify the Roman execution. $C f$. DANIEL JONAH GOLDHAGEN, HITLER'S WILLING EXECUTIONERS: ORDINARY GERMANS AND THE HOLOCAUST 5-9 (1996) (condemning the Germans, not justifying the Holocaust, by arguing that the Holocaust stemmed from beliefs held by overwhelming majority of Germans).

71. For further discussion, see Daniel J.H. Greenwood, Beyond Dworkin's Domin- 
Majority rule; then, always threatens to degenerate into tyranny of the majority. Unless each group or individual consistently receives a roughly proportional share of the victories, the principle of equal membership seems to be violated. ${ }^{72}$ Unless the majority acts justly, justice is not served. ${ }^{73}$

\section{c. The Boundary Problem}

The "majoritarian difficulty"-its potential violations of the principles of fairness and proportionality and that might does not make right-is compounded by the fact that a majority only exists within a given set of decision-making boundaries, and losers nearly always can imagine an alternative set of boundaries in which they would have won. Majorities should win, but majoritarian theory alone cannot explain why the majority that determines whether Boulder has a gay-protective civil rights law should be the majority of Boulder, the majority of Colorado, the majority of America, the majority of the United States Supreme Court, or the majority of the signatory parties to the International Declaration of Human Rights. Nor can it explain whether the election on the future of Northern Ireland should include only Northern Ireland, all of Ireland, all of Great Britain, or each Irish religious community voting separately.

Once the losers have seen that alternative boundaries will result in different majorities, though, the decision no longer seems to be the result of a majority decision. Rather, the decision-and indeed the majority itself-is the result of morally arbitrary line drawing. ${ }^{74}$

ions, 72 TEX. L. REv. 559 (1994) (book review) and Greenwood, Akhnai, supra note 45, at $339-40$.

72. See, e.g., Richard Briffault, Lani Guinier and the Dilemmas of American Democracy, 95 COLUM. L. REV. 418, 464-66 (1995) (book review) (discussing Guinier's "taking turns" principle, which would require the majority to share power with the minority).

73. See, e.g., Plato, APOlogy of Socrates (Thomas G. West trans., Cornell Univ. Press 1971) (Socrates' defense of the laws is Plato's attack on democracy). For a discussion of a less familiar early text that endorses the majoritarian principle while recognizing this problem, see Greenwood, Akhnai, supra note 45, at 339-42 (discussing early commentary on the Levitical text "follow the majority to do right").

74. For attempts to create a theory of boundary drawing, see Miller v. Johnson, 515 U.S. 900, 928 (1995) (O'Connor, J., concurring) (emphasizing importance of "customary" districting principles without explaining why custom is not also arbitrary and potentially unjust to traditional losers); Shaw v. Reno, 509 U.S. 630, 647-49 (1993) (asserting that the creation of majority/minority districts in an effort to separate racebased block voting was not sufficiently justified); Gomillion v. Lightfoot, 364 U.S. 339, 347 (1960) (finding that a re-districting measure that intends to segregate white and black voters violates the Constitution even when justified as an attempt to reorganize political boundaries). For a general discussion, see Symposium, Surveying Law and Boundaries, 48 STAN. L. REv. 1037 (1996). The academic discussion is massive; some further discussion and a few cites can be found in Greenwood, Akhnai, supra note 45, at 336-39. 


\section{Democracy's Discontent}

These problems-the majoritarian difficulty, the might-does notmake-right issue, and the boundary problem-limit the extent to which democratic systems can justify relying on majoritarian decisions. Perhaps as a result, majoritarian systems tend to develop mechanisms to limit the power of majorities. These mechanisms include ideological demands that majorities set aside their own interests; multiple jurisdictions (so that different groups will be majorities in different fora, thus limiting the problem of majority tyranny but accentuating the boundary debate), removal of particularly salient issues from the majoritarian political agenda (as, for example, the original United States Constitution did with slavery and religion), and voting systems that lead to broad coalitions (whether within each of our two parties or in a post-election parliamentary multiparty coalition) with strong pressure to "log rolling" pluralism, in which even small groups get a share of the pie.

When democracies do not develop these limiting mechanisms internally, they tend to be subject to extreme fissiparous pressure as minorities seek to redefine the boundaries in order to become majorities. Thus, countries with well-defined minorities develop welldefined secession movements; on a smaller scale, sects-whether religious or political-split over major decisions. ${ }^{75}$

\section{Markets and Their Failings}

One way to avoid the majoritarian difficulties is to avoid making winner-take-all decisions. Political structures can limit winners' victories, as we have seen, through the structures of pluralism and federalism, including coalition building, logrolling, multiple jurisdictions, proportional voting, and so on. Alternatively, the majoritarian political process can defer to alternative decision-making procedures that do not suffer from the winner-take-all problem. One way to do this is through markets (another is through the classic liberal device of the limited, libertarian state).

Markets, like majoritarian elections, aggregate individual preferences. Because they aggregate, both markets and elections are (partial) expressions of the equal concern principle of liberal democracy as partnership. But markets aggregate individual preferences quite differently from majoritarian democracies. And the equality they express is not an equality of membership in the first instance, but an equality of dollars.

First, markets aggregate without a single collective or political

75. See Robert Cover, Foreword: Nomos and Narrative, 97 HARV. L. REv. 4, 16 (1983) (describing the meiotic tendencies of jurisgeneration). 
decision. That, of course, is their great virtue. Each asset-holding individual can decide what type of sneakers she wishes to buy, and a functioning market will aggregate these individual decisions, assure that sneakers are produced to match the demand, and give the individual "voters" the information they need to make an intelligent decision (in particular, in an imaginary fully competitive market without externality problems, the price of the sneaker would reflect its cost to society, allowing individual consumers to make informed individual decisions about the social trade-offs involved). All this is done without anything resembling the time-consuming and divisive debates of democratic politics: within the market, there is no collective decision, no need for collective compromise, and no majoritarian winners and losers.

Because we each can get the sneakers we individually want, the majoritarian (winner-take-all) problem seems to drop out. In a fully competitive market, each individual purchaser should be able to obtain his or her preferred mix of goods, given objective constraints of the purchaser's resources and the social costs of production. Even if the majority always votes for white sneakers, the minority can have red ones. Accordingly, a market "majority" (defined, of course, by purchasing power rather than numbers) is more likely to win something like proportionality rather than total victory.

If this first difference between markets and democracy seems decisively in the market's favor, the second is less so. Market "voting" is by buying. Thus, "votes" are allocated per dollar rather than per citizen; markets are based on the principle that all dollars are the same rather than the political principle of equal membership of citizens. ${ }^{76}$

Relatedly, the market understanding of equality is entirely ahistorical: one dollar is equal to another regardless of its ancestry or past history. Treating citizens' dollars as equal may often be a way of affirming their common membership-by comparison, for example, with aristocratic and caste systems in which some people are barred from transactions regardless of their assets. Thus, equality of dollars is clearly a step forward from Jim Crow, in which even AfricanAmericans who could afford to do so were barred from buying admission to segregated facilities. The link is not automatic, however. In the next subpart, I consider the relation of market equality to democratic equality.

\section{Market Impersonality versus Democratic Concern}

Many of the conflicts of modern politics follow from the conflict

76. This is the corporate, as opposed to partnership, default voting rule. Compare UNIF. P'SHIP ACT $§ 18(\mathrm{e})$ (1914) (equal voting per partner), with MODEL BUS. CORP. ACT $\S 7.21$ (a) (1984) (equal voting per share). 
between market norms and more political forms of the democratic principle of equal membership: whether, for example, electioneering (or medical care) ought to be seen as an attribute of membership in the political community, directly subject to the equal membership of citizens principle, or whether it ought to be seen as part of the economic marketplace, subject to the equal dollar principle. ${ }^{77}$

\section{a. Affirmative Action from Market and Political Perspectives}

Much of the affirmative action debate is easily understood as such a conflict of norms. In an ideal market context, the personalities of the buyer and seller are irrelevant: one hundred shares of IBM sold by a felon is the same as one hundred shares of IBM sold by a saint. All that matters is the product and the price. Furthermore, the market principle is explicitly a-historical-dollars are fungible without regard for where they came from. This is an expression of the market norm, that is, equality of dollars: my dollars should be as good as yours regardless of their provenance or mine.

The market ideal is anonymity. Anonymous buyers and sellers, as in the stock market, must treat each other equally, without regard for personal characteristics other than the product for sale and the cash offered. Outside of the stock market, of course, the product being sold often includes personal characteristics-qualifications, credit-worthiness, and the like-making anonymity impossible. But the market model suggests that we should attempt to approach the stock market's anonymity as much as possible: we should try to set aside all personal characteristics other than the qualifications that are specifically for sale or hire.

If contracts ought to be awarded to the lowest bidder in an impersonal market in which we do not look behind the product or service offered to the moral qualities of the transacting party, market ideals suggest a sharp distinction between qualifications and irrelevant extraneous characteristics, such as the candidate's history or race. On this understanding, the problem with racism is that it brings an irrelevant personal consideration (race) into a market context: similar products (candidates) are treated differently. Race almost never will be a relevant qualification; considering it seems a paradigmatic violation of the principle that economic decisions should be made without regard to the personal characteristics of the market actor. Thus, the market anonymity norm clearly leads to race-blindness.

Furthermore, on this view, affirmative action is closely related to

77. See generally WALZER, SPHERES OF JUSTICE, supra note 40 (discussing the applicability of different rules to different spheres). 
the harm it seeks to avoid: affirmative action, by treating minority contractors differently from others, treats one individual's dollars, products, or qualifications as different from another's. Under the market understanding, affirmative action can only be justified as a specific remedy for offsetting racism: if racism leads to systematic undervaluing of minority group members' qualifications, then a countervailing thumb on the scale might balance out matters.

On this model, though, past discrimination is essentially irrelevant and cannot justify current discrimination. Defenses of affirmative action must be in the present tense: some form of current discrimination is leading to current undervaluing of the qualifications (or money, or characteristics) of minority candidates. ${ }^{78}$

Defenders of affirmative action, in contrast, often see the issue as one of politics, not economics. Members, not their qualifications or cash, are central to this model. On this political rather than market view, the issue is one of equal concern for members of the political community. It seems evident that some members, and even more clearly some groups, historically have not benefited from our common enterprise to the same degree as others. Indeed, Jim Crow is best understood as a simple rejection of the Fourteenth Amendment promise of equal citizenship: ${ }^{79}$ African-Americans were excluded from membership.

In a mutual assistance association, it is entirely appropriate for those who lost out on one deal to win on another: indeed, to create "rough equality" it is mandatory that those who were disfavored in the last round be favored in the next. We teach our kids to take turns, after all. On this view, preferences for the formerly disadvantaged are not violations of equality but the only way to achieve it.

78. See City of Richmond v. J.A. Croson Co., 488 U.S. 469, 509 (1989) (evaluating an affirmative action plan in terms of evidence of current intentional discrimination or lack thereof). There is much evidence, of course, that current discrimination remains quite significant, so that the same product, or set of qualifications, is routinely rated higher if it is produced by a high status group member than if by a low status group member. See, e.g., ClAUDE S. FISCHER ET AL., INEQUALITY BY DESIGN: CRACKING THE BELL CURVE MYTH 3-21 (1996). My analysis does not reach the suggestion in some Supreme Court opinions that only purposeful, invidious or intentional discrimination could justify affirmative action. See, e.g., Washington v. Davis, 426 U.S. 229, 238-48 (1976) (finding that an employment exam with a racially disproportion impact was not necessarily unconstitutional if it was implemented without a discriminatory intent). Unconscious or unintentional discrimination seems to violate both market and partnership principles just as much as the clearly malevolent variety. When an individual's cash or qualifications are treated as inferior because she or he is a minority group member, both principles are violated - whether or not there is an offender with mens rea.

79. U.S. CONST. amend. XIV ("No state shall make or enforce any law which shall abridge the privileges or immunities of citizens of the United States . . . nor deny any person within its jurisdiction the equal protection of the laws."). 
Thus, minority race itself, as a signifier of past discrimination, may not be irrelevant but the most central personal characteristic of all.

On this view, there is no need to demonstrate that the current city council is (consciously or unconsciously) discriminatory: if a minority group has finally won control, it is entirely appropriate for it to favor those who were disfavored in the past. Turn-about is fair playnow it is someone else's turn. History is not irrelevant but utterly central; pedigree matters. On this view, even innocent beneficiaries of past discrimination are beneficiaries nonetheless. Those who have less than their fair share ought to have a chance to make up for the past. In short, on the political view, "race-blindness" instituted midstream is an unfair change of the rules when the other side might finally be able to win-merely a continuation of the old discrimination. ${ }^{80}$

\section{b. Market Equality versus Democratic Equality}

Market equality can be explicitly opposed to democratic equality. Markets treat dollars as equal. People in markets are equal only to the extent that they have equal dollars. Democratic principles, in contrast, require that we treat members as equals, and dollars are not members. Often, of course, markets will be useful, if partial, tools to implement equal membership, and generally treating members' dollars as equal furthers the goal of treating the members themselves as equals. But there can be no assurance that they will always do so; the proper place of markets in a democracy must always be debated.

\section{Market Difficulties}

Markets also have other distinctive problems.

\section{a. Aggregation Errors}

The first set might be referred to as aggregation errors. Unlike majoritarian politics, markets do not invite citizens to consider the common good or offer the possibility of a politics of friendship. On the contrary, markets often preclude any but self-interested considera-

80. The argument assumes that advantages are passed from generation to generation. Were it the case that each generation begins afresh, the political view would need to confront a difficult argument about the status of groups in a democracy: is injury to one group member appropriately repaired by reparations to another member of the same group (assuming, counterfactually, that group boundaries are fixed and obvious)? See, e.g., BORIS I. BITTKER, THE CASE FOR BlACK REPARATIONS 71, 90-104 (1973) (arguing a case for reparations based on current injuries). If, however, as I have assumed in the text, past history affects current resources, the contrast between market and political views is sharpened. On a market view, the only issue is how much cash (or qualifications) the participant has to offer, not where they got them; in contrast, political views would want to redress past injuries even if no one now alive were at fault. 
tions. ${ }^{81}$ People pursuing their individual interests sometimes will be led, as by an invisible hand, to remarkably perverse results: markets for lemons, monopoly distortions, excessive production of negative externalities (such as torts or pollution), underproduction of public goods, strategic betrayal of the prisoner's dilemma variety, "arms races" or Frank's "big antler problem," "82 and so on. In these cases, the market fails as a aggregative system within its own framework, much as a democratic voting system does when its results are determined by Arrow's paradox, or agenda manipulation. ${ }^{83}$ That is, they reach results that seem clearly wrong simply as aggregations of the relevant individual preferences, without reaching deeper problems of how those preferences were formed or whether they are all that count.

A classic utilitarian thought experiment suggests we imagine an entire society as if were a single person who experiences all the pain and pleasures of all the individuals in the society. A proper aggregation would then be one that such an aggregate person might experience. These first market failures aggregate in a way the single being never would: for example, the aggregate person would immediately seek to eliminate nearly all zero-sum status competitions, would alter the price and production functions of monopolies, would act as if all externalities were internalized, and so on. Rawls' objection to utilitarianism, that this type of aggregation does not take seriously

81. For an example of how a market can make even other-directed individuals act as if they were purely self-interested, see Greenwood, Essential Speech, supra note 10, at 1046-48.

82. Frank's argument is that in situations where relative rather than absolute resources count, competition may drive rational maximizers to actions that collectively are bizarrely irrational. FRANK, supra note 46, at 124-46. Each moose (or country or mafiosi) wants to carry a bigger weapon than his opponent. Pursuing dominance, each individual is driven to invest in an ever-larger tool. From a collective perspective, however, only one can have the biggest no matter how hard they compete. Accordingly, all this effort is largely wasted: if everyone reduced their weaponry by half, the competitive result would be unchanged, but resources would be saved and negative collateral consequences reduced. In general, in any circumstance where competition is over relative status rather than absolute amounts, rational individuals will over-invest in socially unproductive ways; the invisible hand leads to major inefficiency. Veblen, of course, long ago suggested that virtually all economic activity is of this zero-sum relative status nature. THORSTEIN VeBLEN, ThE THEORY OF THE LEISURE Class 41-80 (Houghton Mifflin Co. 1973) (1899). More optimistic views might question the economists' assumption that we are all competitive maximizers: even among baboons, the most successful competitors sometimes are those who understand how to build coalitions or suppress the naked drive to individually maximize. SAPOLSKY, supra note 56, at 98,170 .

83. Kenneth J. Arrow, Economic Welfare and the Allocation of Resources for Invention, in RATE AND DIRECTION OF INVENTIVE ACTIVITY: ECONOMIC AND SOCIAL FACTORS 609, 614-16 (National Bureau of Economic Research ed., 1962). 
the differences between people, ${ }^{84}$ is not, I think, relevant here: entirely self-regarding individuals would agree that they would be better off without any of these market failures. That is what I mean by calling them aggregation errors: the people whose views or actions are being aggregated would pick a different collective and individual result if they could escape the imperatives of the particular market failure.

Markets fail in yet a different way when, with or without political guidance, they efficiently produce goods that many might consider "bads": cocaine, cigarettes, Saturday Night Specials, kidnapping for ransom, or more controversial items such as violent movies, vacuous television, high levels of geographic mobility, or (at least with sufficient side-subsidies) suburban sprawl. In these circumstances, some-nearly everyone in some instances-would prefer to live in a society where these "bads" were not produced even in the face of consumer demand.

\section{b. Collective, Non-Aggregative Results}

A distinct set of problems involves unfortunate results that do not stem from aggregation. As in the case of the extreme income inequality of the last couple of decades, the market may produce a dangerous or disturbing result that is important even though it cannot be understood as an aggregate at all: no one "voted" for inequality even though inequality is an explicable result of individual actions within a particular market framework. And other externalitiespollution, traffic jams-may be similarly unintentional but predictable results of particular market rules.

c. The Majoritarian Difficulty and Boundary Problems in Markets

Markets also raise difficult political issues parallel to the mightdoes-not-make-right and boundary problems of majoritarianism.

First, the fact that a market generates a result does not make it moral, right, attractive, or even natural-just as majority approval cannot transform moral wrong into moral right. In the first group of market failures, the market participants would reject the collective result if they could do so-but as the examples of efficiently produced "bads" demonstrates, it is possible that a market might properly aggregate to a result that, nevertheless, is bad from a perspective outside of aggregation. Market results can be judged by external criteria and often will fail.

Second, markets have issues analogous to the majoritarian boundary problem: like democracies, markets function within set pa-

84. See RAWLS, supra note 2 , at 27 . 
rameters and generate different results based on those parameters. A market in which highways, gasoline, and utility connections are highly subsidized, publicly provided goods; schools, parks and welfare services are provided by local jurisdictions with only easily evaded taxation powers; job training and urban landscapes are purely private, externalizable, costs; and mass transit and cultural institutions are expected to break even, will predictably produce different land use than one in which those rules are reversed. Under different legal rules about union organization, CEO compensation, corporate board elections, minimum wage, employee tenure, or income consumption and wealth taxation, the same market participants would reach radically different levels of inequality. It is not so much the market nor its participants' tastes but these background rules-analogous to the political boundaries of political democracies-that make the difference between Paris and Houston, Denmark and the United States. For this reason, all modern democracies restrain, direct, guide, and manipulate the markets they live by.

\section{The Boundary Problem I: Background Conditions to Make Choices Voluntary}

The most important boundary for markets is the boundary between voluntary and involuntary transactions. The former are the ones the market honors; the latter are theft, oppression, force, fraud, hostage taking, and other crimes ${ }^{85}$ Strong policing of this boundary is necessary for markets to function effectively or efficiently ${ }^{86}$

A voluntary transaction is one to which parties agree, under some set of background conditions-excluding promises of broken kneecaps, for example. Presumably, each party agrees to the transaction because it concludes that it is receiving at least as much as it is giving. This, of course, is the familiar argument for why markets are fair: assuming the background rules sufficiently define voluntary agreements, each side has agreed to the deal, each side views itself as better off after the transaction than before it, and the world as a whole has improved in a pareto optimal way. After the transaction, both parties are better off, no one is worse off, and coercive or otherwise improper exercises of power appear to be non-issues.

In this picture, competitive markets cannot be coercive or redistributive unless something is wrong with the background conditions. Background rules do make a difference, though. If King John

85. The rule that only voluntary contracts are enforceable is both fundamental and ancient. See, e.g., BABYLONIAN TALMUD, Baba Batra 48b (noting the rule).

86. See, e.g., ANDREI SHLEIFER, INEFFICIENT MARKETS: AN INTRODUCTION TO BEHAVIORAL FINANCE 190-93 (2000) (citing evidence that strong protection of minority investors leads to more effective capital markets). 
cannot police Sherwood Forest and Robin Hood offers his rich victims a deal the terms of which are "your money or your life," a nobleman who turns over his assets has made a choice to do so and presumably views himself as better off than if he had taken the other alternative. Thus, he has sold something for equivalent or better value, and the transaction appears to be pareto optimal. Yet it surely is both redistributive and coercive, whether or not it is efficient: any reasonable nobleman would prefer not to be offered the transaction at all. ${ }^{87}$

The challenge for market theorists is to define a set of background rules that clarify the differences among Robin Hood's proposed transaction, a railroad that proposes to be paid not to emit sparks that will burn the farmer's field, a dock owner who refuses to allow port in a storm, a monopolist that refuses to serve a customer except at an exorbitant price, the grocer who offered Jean Valjean a choice of "your money or no bread,"88 or an employer who proposes a transaction of "my terms of employment or no money," so that Robin Hood's transaction is not voluntary and at least some of the others are. If the line is drawn too far towards Robin Hood, protection rackets will be efficient and the market will resemble civil-war era Beirut, Hobbes' state of nature, or Dickensian London more than anything anyone would want to live in $;^{89}$ if it is drawn too far in the other direction, the market will disappear altogether.

More generally, the attractiveness of free trade, voluntary agreements, and the capitalist system generally depends intimately on the legal understanding of "voluntary"-the boundary between binding agreements and coercive illegitimate overbearing. Any persuasive account of voluntary transactions will have to exclude at least some facially permissible market transactions. At some point, a combination of sufficiently poor pay, bad working conditions, and lack of other alternatives, whether due to the prospective employee's limited skills or her limited mobility, begins to look like duress: at the limit, a prisoner's employment contract is not "free" in any meaningful sense. ${ }^{90}$

87. Here, I loosely follow Robert Nozick's discussion in Coercion. Robert Nozick, Coercion, in PHILOSOPHY, SCIENCE, AND METHOD 440, 447-53 (Sidney Morgenbesser et al. eds., 1969). In Anarchy, State, and Utopia, in contrast, he seems to extend the notion of "voluntary" transactions so far that any exercise of private power (but no exercise of state power) appears both legitimate and non-redistributive. Nozick, supra note 6 , at 262-65. I am not sure why one would make such a strong distinction between private and state coercion, although it is evident why, having done so, one would be an anarchist.

88. See, e.g., VICTOR HUGo, LeS MisÉrables (Lee Fahenstock \& Norman MacAfee trans., Penguin Books Ltd. 1987) (1862).

89. See generally COLUMBIA ENCYCLOPEDIA, supra note 14, at 260, 759-60, 1606 07.

90. Compare Alaska Packers' Ass'n v. Domenico, 117 F. 99, 102 (9th Cir. 1902) 
Baby selling, organ selling, and self-enslavement are not permitted in decent market societies, perhaps because it seems hard to believe that any normal person would sell their baby, internal organs, or self except under duress, that is, when faced with a set of choices that no one should have to face. ${ }^{91}$ But these dramatic cases only illustrate a more general point. In practice, we highly regulate all voluntary transactions, or, more precisely, it is only by virtue of regulation that we can define which transactions are "voluntary." The background rules regarding duress, fraud, property, warranties, disclosures, and so on, define the voluntary space.

Even within these broad rules, we regulate the most important markets even further. For example, ordinary labor contracts are sufficiently disturbing that we do not enforce them by injunction; unions can form only under highly constricted conditions; businesses can obtain partial exemptions from usual liability rules by incorporating,

(holding that the employer, not the employee, was subject to duress when it agreed to modification of terms of employment after relative bargaining power had shifted), with HuGo, supra note 87 (arguing that Jean Valjean was not offered a sufficient range of choices).

91. See, e.g., In re Baby M, 537 A.2d 1227, 1234 (N.J. 1988) (holding that a surrogate parent contract was unenforceable under a baby-selling statute). For an alternative view that the ban on baby selling is based on a concern for the effect on the parent/child relationship that would result from commodification, see ELIZABETH ANDERSON, VALUE IN ETHICS AND ECONOMICS 170-89 (1993). Anderson asserts that "[t]he widespread acceptance of contract pregnancy could psychologically threaten all children. For it would change the way people (parents and brokers) value children generally ... to being sometimes the alienated objects of commercial profit making." Id. at 172. She notes that these people "accept the legitimacy of paying mothers to undermine their love for their children," and that "[t]hese actions ... [are] inconsistent with parental love." Id. Anderson's argument, which focuses on the relationship of the seller to the sold and the self-image of the object sold, would not apply to organ selling. An alternative argument focusing, as I do in this Article, on the vendor rather than the object sold, might center on the "asymptotic time discounting problem" (a.k.a. the Ulysses and the Sirens problem, see e.g., HOMER, THE ODYSSEY (A.T. Murray trans., Harv. Univ. Press 1995)): that people often have trouble resisting immediate temptations even when they know they will regret succumbing (to another handful of potato chips, for example) later on. See, e.g., RICHARD H. THALER, QUASI RATIONAL ECONOMICS 96 (1991). We might imagine that the only person who would sell an organ, a baby or himself is someone whose immediate need for money creates an irresistible temptation, even though he will regret the decision later (and may even be aware of that while making the decision). Were this the concern, transactions made well in advance with deferred payment (such as the surrogate parenthood at issue in $B a b y M$ ) would be of less concern than a spot market (as in more traditional baby selling). As the Baby $M$ trial court thought, with both the transfer and the payment well in the distance, potential sellers might be able to make a reasoned decision while still out of hearing of the call of the Sirens of immediate temptation. See In re Baby M, 525 A.2d 1128, 116364, 1166-67 (N.J. Super. Ct. Ch. Div. 1987), rev'd 537 A.2d 1227 (N.J. 1988). For that reason, I reject this explanation: the more important question seems to be whether the transaction is so degrading that free women should see it as beneath their dignity. This is a quasi-empirical moral question. 
but if publicly traded are subject to an extensive prior-restraint speech system in order to allow a free market in securities to function; necessities such as education, roads, gasoline, farm products, water, and utilities (and in other countries, medical care, pensions, and trains) are often highly subsidized or otherwise regulated, as are aspects of our cultural heritage such as baseball stadiums, libraries, Western ranchers and military bases. ${ }^{92}$ Whatever moral power voluntary agreements have, it is not strong enough to make them irrevocable or fully freely negotiable even where the contracting parties do seem to have a range of options. ${ }^{93}$

Voluntariness, in short, seems to be the key to many judgments about the proper range of market transactions. And the key to voluntariness seems to be in the range of choices available: the more the individual has a wide array of alternatives, including practical alternatives to even considering the transaction (no, Mr. Hood, I'd rather be held up by the guy who is offering to pay the rich ...), the more the transaction seems voluntary and the more pareto optimality seems attractive. Other aspects of voluntariness involve judgments about the particular object of choice, or efforts to restrict the range of variation so that bargaining can efficiently focus on just a few salient choices.

\section{The Boundary Problem II: Protection Rackets and Free Markets}

The individual's range and objects of choice are not the entire story, however. Collective (political) moral and legal judgments about legal entitlements also determine market results. The usual understanding of the Coase Theorem ${ }^{94}$ is precisely wrong: the accepted background rules, not personal preferences, are the most important factors in determining how social resources will be used.

Consider Coase's famous example of the conflict between a rancher and a farmer. ${ }^{95}$ Farmers grow grain; ranchers' cows eat the farmers' grain. Coase argues that, in the absence of transaction costs, it does not matter whether this conflict of uses is viewed as the

92. Lumley v. Wagner, 1 De G. M. \& G. 604, 42 Eng. Rep. 687, 693 (Ch. 1852) (refusing to order prima donna to perform according to her contract); Am. Broad. Co. v. Wolf, 420 N.E.2d 396, 366 (N.Y. 1981) (comparing injunctive enforcement of personal service contracts to "involuntary servitude"). Note that in these cases, even privileged actors with a wide range of options are not deemed to have agreed to choices or commitments that it seems unreasonable for one to make.

93. See, e.g., Grant Gilmore, The Death of ConTract 87-103 (Gryphons Editions 1997) (1974) (arguing that contract law, like tort law, reflects social judgments about the way relations ought to be conducted).

94. R.H. Coase, The Problem of Social Cost, 3 J.L. \& ECON. 1 (1960).

95. Id. at $2-8$. 
farmer interfering with the rancher or vice-versa. That is, the resources will be used in the same way whether farmers have a property right to recover the damage that free roaming cows cause or ranchers have a property right to let their cows run free. Regardless of who receives the property right initially, it will be traded until it ends up in the hands of the party that values it most highly. This is Coase's Invariance Principle: marginal costs and consumer preferences, not legal entitlements, determine the social allocation of resources.

As Coase emphasizes, the Theorem's invariance principle applies only in a world of no transaction costs. When transaction costs are high, as they usually are, no trades will take place. Thus, allocating the property right to the farmer means more grain and fewer cattle, since the farmer's costs of production will be lower and the rancher's higher than with the reverse allocation.

When transaction costs are low, Coase argues, resource use will be the same regardless of who receives the initial property right, because one party will have the cost of liability as a cost of production and the other will have an equal opportunity cost of a lost liability claim as a cost of its production. The Coase Theorem states that when (as in a world without transaction costs) costs and opportunity costs are the same, the marginal costs of production are the same under the two property regimes and therefore the social allocation of resources will be the same. ${ }^{96}$ The property right has no effect - the final allocation is driven only by relative marginal costs (and, ultimately, consumer preferences).

But costs and opportunity costs differ in a number of important ways, not the least being what Coase refers to as the income effect. Farmers for whom ranchers are an opportunity cost have a higher income than farmers who must pay them to go away: the former re-

96. Coase's argument runs something like this: imagine that each head of cattle the rancher adds does a predictable amount of damage to the farmer's crops, say $\$ 10$. If the property right is allocated to the rancher, the farmer should be willing to pay any amount up to $\$ 10$ to avoid that damage, so long as the marginal profit of farming (absent ranchers) is more than $\$ 10$. The rancher, in turn, should be willing to accept any amount above his marginal profit from running cattle to sell his rights to run. That means that the right will be sold anytime the rancher's marginal profit is less than $\$ 10$ and the farmer's marginal profit is more than $\$ 10$. Id. at 2-8.

Now consider what happens if the property right is allocated to the farmer. The right saves the farmer $\$ 10$ in damage. The farmer should be willing to sell it for any amount above $\$ 10$, and the rancher should be willing to buy it if his marginal profit is greater than $\$ 10$ (absent farmers). Furthermore, if the farmer can earn less than $\$ 10$ from farming, she should be willing to sell the right and stop farming. That means that the farmer will retain the right anytime the rancher's marginal profit is less than $\$ 10$ and the farmer's marginal profit is more than $\$ 10$. Id. at $15-19$. 
ceive payments while the latter must make them. ${ }^{97}$ This means either that farmers are richer than were the opportunity costs reversed, or, in a world of perfect competition, that the price of grain will be competed down. In the latter case, it seems fairly obvious that we will have more grain and fewer cattle, as the marginal consumer becomes vegetarian. Even in the former case, however, as farmers become richer and ranchers poorer, given the diminishing marginal utility of money, ever richer farmers should require ever larger bribes (or opportunity costs) to deflect them from their preferences, just as ranchers will be ever less able and willing to provide them. If farmers have values (or tastes) that differ from those of ranchers (and that go beyond wealth maximization), the initial allocation thus again will affect whether the final allocation reflects farmer values or rancher values. The invariance principle should be quickly defeated by the income effect in a multi-period world.

Next, as Thaler and others have pointed out, the Coaseian story also relies on the false assumption that farmers and ranchers treat opportunity costs as the same as real costs, or what seems to be the same thing, have a single indifference price at which they are willing to buy or sell: at $\$ 10$, the farmer is indifferent between retaining, selling or acquiring the right to be free of cattle intrusions. ${ }^{98}$ But indifference prices exist largely only in economics textbooks.

In real life, people generally have very different prices for buying and selling: ordinarily, they insist on more to sell something that they own than they would be willing to pay to acquire it. ${ }^{99}$ Think, for example, of what your reaction would have been if someone had offered to buy your newly acquired house on the day of the closing for

97. Imagine the farmer earns $\$ 11$ from the marginal field of grain. A cow running in it does $\$ 10$ of damage. Ranchers, however, only earn $\$ 9$ from this marginal cow. The invariance principle states that the cow will not be allowed to run: the rancher's marginal profit is lower than the farmer's. But if the farmer has the property right, she simply retains it, and her profit is $\$ 11$ (the rancher earns nothing). If the rancher has the property right, the farmer must buy it from him, for $\$ 9$, and her profit is only $\$ 2$ (the rancher earns $\$ 9$ ). While the allocation of resources (cows vs. grain) is the same, the income associated with it is allocated quite differently. In the next time period, this means that the initial property holder will be relatively richer and thus have a relatively greater range of options and a relatively diminished marginal value of money. To the extent that ranchers and farmers also believe in what they are doing, those wealth effects should change the price they will demand for further reallocation of rights. Over successive time periods, the initial property holder will demand ever higher bribes to abandon his or her values and will become increasingly likely to prevail.

98. See, e.g., Daniel Kahneman et al., Experimental Tests of the Endowment Effect and the Coase Theorem, in BEHAVIORAL LAW AND Economics 211, 213 (Cass R. Sunstein ed., 2000).

99. See, e.g., Russell Korobkin, Behavioral Economics, Contract Formation, and Contract Law, in BEHAVIORAL LAW AND ECONOMICS, supra note 98, at 116-37. 
the price paid (including closing costs, compensation for time and so on) plus $\$ 10,000$. Surely it would be a rare person indeed who would accept this opportunity to make a free $\$ 10,000$, even if they had just paid precisely the maximum they were willing to for the house. Even on Wall Street, our most competitive and lowest transaction cost market, everyone assumes that there is a wide range of prices in which investors should "hold" stock: that is, the price is too high to purchase more, but too low to sell.

Accordingly, there is no reason to believe that a farmer would be willing to pay as much to acquire a right to exclude cattle as she would demand to sell that right. Whenever this "hold" position exists (Thaler refers to it as the "endowment affect"), ${ }^{100}$ the initial allocation of property rights will have profound effects on the ultimate resource use regardless of income effects or transaction costs.

Thaler's insight suggests an additional reason to doubt that Coase's Invariance Theorem will apply in any approximation of the real world: farmers and ranchers will take radically different views of the transaction depending on whether they are persuaded it is voluntary. And whether the transaction is voluntary depends on their views of the initial allocation of property rights. ${ }^{101}$

Thus, a farmer who believes that common law trespass rules reflect the natural law of property (and apply to cows) should take a very different view of the transactions Coase contemplates than one who believes that the enclosure movement was one of the great crimes against humanity or that cows have a God-given right to eat what they find..$^{102}$

Imagine, for example, that Coase allocates the initial right to the rancher: cows may wander, and farmers who would like to preserve their grain must fence or pay ranchers not to release the cows. A farmer committed to the law of trespass is likely to see the rancher's claimed right as an oppressive outrage. The rancher is using the

100. Kahneman, supra note 98 , at 213.

101. For a discussion of post-litigation negotiations making a similar point, see Ward Farnsworth, Do Parties to Nuisance Cases Bargain After Judgment? A Glimpse Inside the Cathedral, in BEHAVIORAL LAW AND ECONOMICS, supra note 98, at 302, 314316.

102. The English Enclosure movement transferred village commons to private ownership, thereby eliminating prior rights to grazing and collecting. For further discussion, see G.E. MiNGaY, PARLIAMENTARY ENClOSURE IN ENGLAND: AN INTRODUCTION TO ITS CAUSES, INCIDENCE, AND IMPACT 1750-1850, at 80 (1997). Classic polemics against it are found in OLIVER GoldSMITH, THE DESERTED VillaAge 3-5 (Percy Lund, Humphries \& Co. 1927) (1770); KARL MARX, CAPITAL, in CAPITAL THE COMMUNIST MANIFESTO AND OTHER WRITINGS 59-63 (pt. VIII, chs. 26, 27) (Max Eastman ed., Random House, Inc. 1932) (1867); and J.L. HAMMOND \& BARBARA HAMMOND, THE VILLAGE LABOURER 73-81 (Longman, Green, \& Co. 4th ed. 1932) (1911). 
farmer's property without paying for it. ${ }^{103}$ That is theft. Then, he compounds this injury by demanding that the farmer pay him to stop. That is just a protection racket. And while it may sometimes be rational to pay protection money, it is never voluntary. This farmer, whether or not she pays the protection money, should seek legal protection to bar a fundamentally unjust transaction.

In contrast, imagine a Coaseian allocation of the rights to the farmer, and ranchers who accept the claims of the anti-enclosure movement. Once again, Coase's proposed sale of the initial rights will appear not voluntary but coerced. Cows, and buffalo before them, have wandered the West since long before there were farmers; no one should have to pay bribes simply to continue to practice the profession of his fathers. The farmer's attempt to exclude grazing cows is no more than a land-grab-a violation of the rules of the game and a forcible taking that reasonably can be resisted in kind. Violating the rancher's right to run his cattle on land he does not own is not much better than rustling. ${ }^{104}$ The rancher is more likely to cut fences, join the County Independence movement or demand that Coase be removed from legal authority and the rule reversed than he is to pay the farmer in order to keep what is his anyway. ${ }^{105}$ On this view as well, Coase's proposed trade is not voluntary but theft. ${ }^{106}$ Whether participants view their initial entitlements as reflecting a just legal system or, rather, as no more than oppression in the guise of law, will affect how they respond to the initial Coaseian allocation of rights and what the end results of market transactions are likely to be (including whether they will seek to go outside the market to over-

103. Not to mention promoting a legal view that will impose enormous social costs on the environment and the rest of us. See Garrett Hardin, The Tragedy of the Commons, 162 SCIENCE 1243, 1243-44 (1968) (claiming that in the absence of private property rights, commons will be overused). But see MINGAY, supra note 102, at 34, 128 (noting the ability of the traditional communal jury to regulate use of commons and prevent its abuse). It seems questionable whether equivalent mechanisms protect western federal lands.

104. See, e.g., MARX, supra note 102, at 59-63 (pt. VIII, chs. 26, 27) (characterizing transfer of common lands into modern private property as "robbery," "theft," "usurpation," "expropriation," "acts of violence," "violation of the rights of property," etc.); GOLDSMITH, supra note 102, at 4 (referring to "usurp[ation]"); MINGAY, supra note 102, at 132 (describing sometimes riotous opposition to enclosure).

105. While Coase postulates a farmer and a rancher, in the modern West the conflict is far more likely to be between ranchers and other claimants to federal land, such as hikers and environmentalists, who wish to avoid the damage done to the land by free ranging cattle. And ranchers have not only resisted any change in the initial allocation of rights but have sought to bar even such trades as might happen anyway: for example, by barring non-ranchers from purchasing grazing rights and retiring them. Were buffalo entitled to compensation from ranchers (or farmers) who interfered with their range (or spread disease to them), the West would look quite different than it does today.

106. See discussion supra notes 94-95 and accompanying text. 
turn market results). ${ }^{107}$

The point here is one often made in criticism of simplistic Benthamite criminal law schemes. Bentham (and modern successors) model criminal law as a simple matter of negative reinforcement provided by the government to discourage undesirable behavior. ${ }^{108}$ But negative reinforcement has radically different effects depending on how it is understood by the recipient: if even a dog knows the difference between being kicked and being tripped over, people also know the difference between fair kicks (punishment) and unfair ones (arbitrary oppression). Faced with arbitrary oppression, many people respond by increasing resistance, not by conforming to the oppressor's ideal. In the Intifada, Revolutionary America, late apartheid South Africa, and perhaps even late Soviet Russia, an increase in (illegitimate) governmental force only led to further opposition. ${ }^{109}$ This is also true in this civil context. People will only treat market transactions as voluntary to the extent that they view the underlying background rules and allocations as fair. Perhaps this is why gross increases in CEO salaries are often said to be followed by increases in petty employee theft: one abuse generates another.

In another layer of complexity, the endowment effect is likely to interact with this "righteousness effect." Given any set of preexisting moral or legal beliefs, Coase's initial allocation will tend to "endow" the in-group with a stronger sense of its righteousness. ${ }^{110}$ Again, the final allocation of resources is more likely to be determined by the initial one than by social costs or individual preferences imagined to exist outside of a particular history, a contestable legal context or a changeable set of market boundaries.

Voluntary market transactions, then, only exist within a commonly accepted set of background rules of property and related law. Coase notwithstanding, the background rules, not the market, will largely determine the ultimate allocation of resources. This is because of transaction costs, income effects, endowment effects, and the fact that only the rules and the participants' acceptance or rejection of the rules will determine which transactions are considered voluntary and legitimate and which are not. From the point of view of one participant, paying bribes to the other in order to induce them to re-

107. On the importance of procedural fairness in inducing law-abidingness, see Tom R. Tyler \& Gregory Mitchell, Legitimacy and the Empowerment of Discretionary Legal Authority, 43 DUKE L.J. 703, 724-27 (1994).

108. E.g., BENTHAM, supra note 25, at 155-56, 170 n.1, 181; JAMES Q. WILSON \& RICHARD J. HERRNSTEIN, CRIME AND HUMAN NATURE 489-507 (1985).

109. See generally COLUMBIA ENCYCLOPEDIA, supra note 14, at 86-87, 121-22, 1350, 2823-24.

110. As Professor Herrnstein taught me, even stickleback fish fight harder to defend their home territory than to impinge on another's. 
spect the former's pre-existing property rights is just a protection racket, not economic efficiency. The farmer would be better off if the rancher would just disappear (or if the sheriff would prevent his cows from trespassing), and vice-versa.

The distinction between protection rackets and free trade sets the boundaries of the market. On the one hand, pace Coase, that boundary can no more be determined by purely market forces than democratic majoritarianism can determine the boundaries of the polity. On the other hand, much as political boundaries can determine the results of majoritarian elections, so too will the moral/legal accounts of the boundaries of permissible market transactions determine the results of market transactions. And much as the boundary problem makes majority rule a mere artifact of arbitrary (predemocratic) decisions, so too the malleability of the market's background rules, which cannot themselves be defended on market terms, undermine any claim that the market's results are necessary consequences of market processes. In each case, the system's results can be manipulated beyond the system's own parameters.

\section{Voluntary Markets, Private Power, and Redistribution}

Markets also raise critical issues that are quite different from the majoritarian and boundary difficulties. The coercive power of markets is radically different from that of democratic politics.

Markets function by voluntary self-interested transactions. For current purposes, two aspects are most important. First, markets cannot restrain private power, whether properly exercised or not. Second, voluntary self-interested transactions readily redistribute from the needy to the privileged, but never the other way around. This point is simultaneously obvious and somewhat obscure, so it may be worth exploring in more detail, particularly since the normal framework of undergraduate economics excludes it.

\section{a. Voluntary Transactions and Upward Redistribution: How the Rich Get Richer}

In a well-regulated market economy with an adequate safety net, most people, most of the time, will have sufficient alternatives that market transactions will be voluntary in the necessary sense. In this part, I mean to set aside the Jean Valjean and the baby-selling problems. Even assuming that the background rules discussed above have been set in a reasonable way, markets will create serious problems of power.

Here, I mean to emphasize the opposite of Jean Valjean: for the reasonably well off, a market economy offers so many choices that there is rarely any reason to accept an unattractive deal. That is, markets do not coerce participants who have an array of choices. 
Since markets do not limit the freedom of action of those with choices, they do not regulate. Rather, markets allow those with market-attractive resources to do just as they please.

It follows then that markets never redistribute income, power, privilege, or wealth from the better off to the worse off. This is true in a tautological sense if "better-off" is defined as having more of those resources that the market values: those individuals always have a wide range of choices and can simply decline to participate in redistributive enterprises.

If "better-off" is understood in any other sense, it is a generalization to which there will be many exceptions. Most notably, markets are not respectful of past status hierarchies: even before the coming of the messiah, in market economies "those who are last, they shall be first." "1' Markets will mercilessly take from those with bad luck or poor timing regardless of current status. They also allow some individuals in the right place at the right time to convert that place advantage, particularly if it is accompanied by good ideas, initial wealth, hard work, and good luck into sometimes startling wealth. On a broader scale, kids who perform well (or poorly) in school (or are lucky or unlucky in their choice of career) are likely to have significantly higher (or lower) incomes than their parents.

Of course, one should not exaggerate the mobility of our market society. Since place advantages often build on themselves, markets do not churn the income distribution as much as popular myth sometimes suggests. At the middle class level, having well-off parents is a strong predictor of doing well in school. ${ }^{112}$ At the very top, many rags to riches stories turn out to be, rather, riches to super-riches: George Bush, Bill Gates and Donald Trump are prominent examples of selfmade men who were born to very wealthy families. ${ }^{113}$

However, to whatever degree markets churn their participants' positions within the income distribution, they will not set out-as political systems occasionally do-to reduce the gaps between rich and poor, to ensure that the better-off turn over some of their wealth to the worse-off in a systematic way, to ensure that everyone receives a decent minimum, or to prevent the very rich from fully exploiting their relative advantage. It is extremely difficult to use markets as a tool for achieving distributive justice (or, for that matter, social stability). People with choices simply will choose not to give up their

111. Matthew 19:30.

112. FISCHER, supra note 78, at 92-93, 153, 194-96.

113. See generally Bill Mintuaglio, First SON: GeORGe W. BuSH AND THE BuSH FAMILY DYNASTY 19-38 (Random House Inc. 2001) (1999); ROBERT X. CRINGLEY, ACCIDENTAL EMPIRES: How THE BOYS OF Silicon Valley Made THEIR Millions, BaTTLED Foreign CoMpetition, and Still Can't Get a DATE (1992); Gwenda Blair, The TRUMPS: THREE GENERATIONS THAT BUILT AN EMPIRE 105-94, 223-453 (2000). 
privileges; markets will not require them to do so. Markets are therefore a poor tool for downward redistribution.

Markets do, however, redistribute upwards routinely. Given the diminishing marginal utility of money, it takes more money to make any given transaction attractive to a wealthy party than to a poor one. The rich guy, after all, can always go hang around on the beach; the poor one has to eat. If it takes more to attract the rich than the poor-because the former have more options and can be pickier-it seems to follow necessarily that even when market transactions are voluntary (in the sense outlined above, namely that market players have sufficiently attractive alternatives to the particular transaction), and even when each of the players are better off with the transaction than without it, the wealthier participant-the one who can walk-is likely to end up with relatively more than the less independent participant.

Thus, pop business advice books point out that the key to negotiation is being willing to walk; the one who can walk will always get the better deal. To attract and keep successful CEOs, companies believe they must offer million-dollar salaries, and then still moremultimillion-dollar stock option plans re-priced to retain their value even if the company's stock does not-to provide these expensive executives with an adequate "incentive" to do the job they were hired to do. To attract and keep essential line workers, it is generally assumed that far less is necessary. ${ }^{114}$

If indeed it is the case that the rich can demand more of the surplus created by trade, whether in a particular negotiation or more broadly, the market redistributes upward in this sense: market transactions, ceteris paribus, are likely to lead to increased inequality. Precisely because each party to the transaction must receive something of at least as much subjective value as what they give up,

114. In 1974 the average CEO of a large American corporation earned 35 times the salary of the average manufacturing worker. FRANK, supra note 46, at 67 . By 1990 , the ratio was 150 . Id. According to Business Week, using a somewhat different calculation method, by 1999 , the ratio had increased to 475 : the average CEO, with a pay package of $\$ 12.4$ million, received each working day more than double the annual pay of an average blue collar worker. Jennifer Reingold, Executive Pay, BUSINESS WEEK, Apr. 17, 2000 , at 100. Since an ever-increasing percentage of CEO income is in the form of difficult-to-value stock options, recent pay estimates are inherently less accurate than earlier ones. Stock options began to dominate CEO pay in 1983. Executive Pay, Up Up and Away Timeline, BUSINESS WEEK, Apr. 19, 1999, at 34. CEO pay continues to increase far faster than employee pay, and there is no reason to believe that the trend will change in the near future. In contrast to the monotonic rise in inequality since the mid-1970s, earlier periods show that progressive income taxes, restrictions on stock option grants to executives, and stock market crashes (at the top) and increases in the minimum wage and unionization (at the bottom) each have dramatic equalizing effects. For more general information on income inequality, see discussion supra note 39 and accompanying text. 
the market assures that those with more, get more. Nor is this contradictory to economic efficiency: if everyone is better off (in terms of the value of the goods they command), the transaction is efficient in the usual sense of the word.

These efficient market transactions, by making the wealthy wealthier faster than the poor, increase the gap between rich and poor. That gap, in turn, is often as important as absolute numbers: relative wealth often matters more than absolute wealth. ${ }^{115}$ In hiring, for example, the master's wealth relative to the servant's is far more important than the absolute amounts concerned. And in politics, it has long been recognized that radical inequality threatens republican democracy.

A critical failing of markets, then, is that left to their own, markets tend to accentuate, not mitigate, preexisting inequalities. A functioning market is a sort of reverse Robin Hood: it gives more to the rich than the poor. The counter-Coaseian problem discussed in Part II.B further increases market-created inequality. The party issued the initial allocation of rights will have a permanent, ever increasing, head start: first, because the endowment effect makes wealth in the hands of the endowed party worth more; second, because the endowed party will be accepting bribes rather than paying them (the income effect); third, because in the second period, the endowed party, now wealthier and therefore with a diminished marginal utility of money, will require a still larger bribe to give up its rights; and fourth, because the endowed right effect will create an aura of legitimacy for the initial unfair endowment. In the first instance these effects (along with standard transaction costs) mean that a sub-optimal number of trades will occur. Further, however, they mean that the trades that do occur will tend to further enrich those made wealthier by the initial endowment in a cascade. As the aphorism goes, the rich get richer. ${ }^{16}$

More generally, the more open and competitive a market is, and the more resources a market participant commands or the more op-

115. For a claim that relative status is far more important than absolute amounts of wealth, at least where starvation is not at issue, see VEBLEN, supra note 82, at 35 (arguing that property is not valued for the possibility of consumption but rather because wealth is an invidious distinction, providing its possessor with honor, and thus that the collective desire for wealth cannot be satisfied because its ground is "the desire of everyone to excel everyone else in the accumulation of goods"). For examples of modern treatments, see FRANK, supra note 46 , at 67 (making argument similar to Veblen's with respect to many modern competitions) and FISCHER, supra note 78, at 129-57 (arguing that inequality results from social choices regarding the number of "winning" spots).

116. Where the initial allocation was racist, this also suggests that neutral markets will accentuate the original sin rather than washing it out. See discussion supra Part III.C.1.a. 
tions that participant has, the less the market can coerce the participant. That is the sense in which markets promote individual freedom. But individual freedom is not always the same as collective freedom; otherwise we would all be anarchists. When freedom is relative, as it is in markets, the increased freedom or wealth of the rich means fewer options for the poor. Markets tend to accentuate initial inequalities, not reduce them.

Since "voting" in market systems is by purchase decisions, property rules that give wealth to one party rather than another also determine whose views count for more in the next round. Functioning democracies tend to dilute victories over time, as the winners in one round lose in another; in contrast, markets tend to accentuate small initial victories into ever-larger conquests, as the rich get richer ever faster in a cascade. There is no avoiding the conflict between democratic norms of equal respect (which often require taking turns) and the a-historical market norm of treating all bidders the same.

\section{Civil Society: Aggregation by Membership and Governance by Exit}

Democracies consist of more than just majoritarian politics and economic markets. Voluntary associations-the civil and political associations that de Tocqueville saw as the distinctively American contribution to democratic life-remain critical to American selfgovernance. ${ }^{117}$ Albert Hirschman has explained the key decisionmaking structures for this sector; his "exit," a market-like aggregating process, is the key mechanism in the "market" for voluntary associations as well as corporate law and some regulatory law. ${ }^{118}$

Hirschman describes an evolutionary process of governance by selection. ${ }^{119}$ When individual decision-makers find the product of an organization (or the organization itself) attractive, they join. If they find the reverse, they exit. Organizations prosper or fail to some degree based on the extent to which they are able to attract members, much as producers in a market succeed or fail depending on whether they are able to attract customers. In each case, the organization can be controlled without any direct political mechanism: even an organization with no representative institutions whatsoever may represent its members if they are free to enter and exit, just as companies may be able to produce what their customers want without any formal mechanisms for customers to voice their preferences. ${ }^{120}$

117. Alexis De TOCQUeVIlle, Democracy in AMERICA 189-95 (vol. I, pt. II, ch. IV), 520-24 (vol. II, pt. II, ch. VII) (George Lawrence trans., J.P. Mayer ed., HarperCollins Publishers First Perennial Classics ed. 2000) (1795).

118. See generally Albert O. HIRSCHMAN, EXIT, VoICE AND LOYAlty 21-29 (1970).

119. Id.

120. Id. 
Like markets, control by exit is control by Darwinian selection: those organizations that adapt, succeed. Like biological evolution, success and adaptation in this context are defined tautologically. "Adapted" means no more than able to survive (and prosper?) in a given environment-it may have only limited implications as to ability to survive in some other environment and none at all as to beauty or morality or any other value. ${ }^{121}$ Survival of the fittest means just that those that are able to survive, survive: what they are fit at is survival under the conditions in which they survive (and fittest only by comparison with those who do not survive). Nothing more: in civil society, as in markets and elections, survival or success do not necessarily equate to desirability.

In a system of organizational selection by exit, survival has two important implications. First, the current participants are satisfied enough (or find the alternatives sufficiently unattractive) to remain in the organization. It follows that the organization, whether by design or accident, is meeting some need of its members (or they are constrained from leaving for some reason). Second, the members are numerous (or wealthy) enough to sustain it.

Hirschman's most important insight is pointing out that where exit is both simple and unconstrained, internal democracy may be relatively otiose: those who are unhappy with current policies are more likely to depart than to protest. ${ }^{122}$ This is, no doubt, a key reason why corporate shareholder elections so rarely are contested and so often result in voting results that look more like Leninist plebiscites than democratic debate. Shareholders control corporations largely by a Hirschmanian process, following the "Wall Street Rule" (sell, do not protest, if you do not like what management is doing) when they dislike policies and bidding up the shares of firms they find well run. ${ }^{123}$ Internal electoral politics are largely unnecessary to assure alignment of management and (current) shareholders since those who disagree with management will simply leave. ${ }^{124}$

Exit differs from market in that voting is at least partly per participant, rather than per dollar, and it is more democratic to that extent ("partly" because the organization may be more interested in dollar support than numbers of members). Corporations, however, are a significant exception to this generalization, since both corporate

121. See, e.g., Steven J. Gould, Ever Since Darwin: Reflections in Natural History 34-38 (1977); STEven J. Gould, The PANDA's Thumb 54-58 (1980) (emphasizing the difference between natural selection and engineering).

122. HIRSCHMAN, supra note 118, at 21-29.

123. See, e.g., Doug Henwood, WALl STREet (1998) (describing the atmosphere, concerns and general nature of a Wall Street brokerage firm).

124. See Greenwood, Fictional Shareholders, supra note 10, at 1056-65. 
voting and exit are per share (or per dollar), not per capita. ${ }^{126}$

The coercion issue differs somewhat as well. As in markets, the key issue is choice. Whether individuals have an effective right of exit depends on the collateral costs of exit as well as the range of alternatives available. If the range of choices is wide enough, a system of exit extends great freedom to participants and largely eliminates the ability of the various institutions to coerce their members.

In the corporate law context, we rely almost exclusively on exit to limit the firm's ability to coerce its non-shareholder participants. Thus, customers have various legal rights (for example, breach of contract and breach of warranty) but the one that allows them some control over the firm is the right to take future business elsewhere. The importance of exit is most obvious in the case of (non-union) employees who, under the doctrine of employment at will, are understood to have virtually no other procedural or substantive rights on the job. ${ }^{126}$ Of course, whether exit is a useful source of protection to employees depends on whether they are genuinely mobile: whether they have commitments, social or otherwise, to their current jobs, and whether they are (and know they are, and employers believe they are) able to find similar ones elsewhere.

125. I have argued that in other ways as well, the shares, not the human shareholders, should be understood as the members of (or beneficiaries of) publicly traded corporations. See Greenwood, Fictional Shareholders, supra note 10, at 1025-26; Greenwood, Essential Speech, supra note 10, at 1041-44.

126. The doctrine of "employment at will" presumes that an employee accepts the employer's proffered terms (whether known or unknown) by accepting and remaining on the job, because a servant is understood (as a matter of law) to consent to direction and control by the master. See, e.g., RESTATEMENT (SECOND) OF AGENCY §2(2) (1998). Economic reality is often to the contrary - that is, employers accept employees' terms by hiring or retaining them - but, as many "lifetime employees" have discovered to their dismay, the courts will not enforce those bargains when they are made, as they usually are, informally. See, e.g., Smith v. F.W. Morse \& Co., Inc., 76 F.3d 413, 427 (1st Cir. 1996) (construing term "permanent employment" to mean "employment at will"); Shelton v. Ernst \& Young, LLP, 143 F. Supp. 2d 982, 992 (N.D. Ill. 2001) (noting that "courts impose substantial obstacles in the employee's path of overcoming [presumption of at-will employment)" (quoting Krieger v. Adler, Kaplan \& Bogy, No. 94 C 7809 , 1996 WL 6540, at *6 (N.D. Ill. Jan 5, 1996) (citations omitted))); Degen v. Investors Diversified Servs., Inc., 110 N.W.2d 863, 864-66 (Minn. 1961) (assurance that employee "shouldn't look forward to anything else other than a long career with the company" created no contractual rights); Shebar v. Sanyo Bus. Sys. Corp., 544 A.2d 377, 380-83 (N.J. 1988) (describing common law employment at will doctrine and creating limited exception where employee specifically alleged reliance to his detriment on an oral assurance that he was "married' to [the company] and no divorce was allowed"); Woolley v. Hoffman-La Roche, Inc., 491 A.2d 1257, 1265-1270 (N.J. 1985) (enforcing written limitations on termination for cause while noting that the company could have changed its policy manual at any time); Weiner v. McGraw-Hill, Inc., 443 N.E.2d 441, 445 (N.Y. 1982) (describing common law doctrine and creating limited exception where employee relied on written policy manual creating procedure for termination for "good and sufficient cause only"). 
Shares in contrast do have a few formal governance rights (both procedural and substantive). Nonetheless, free exit remains their most important control mechanism: it is generally assumed that shareholders influence the corporation mainly by driving the price of its stock up or down as they buy or sell. Ease of exit by individual shareholders means that public corporations rarely can oppress shareholders, although they often disappoint them. ${ }^{127}$ In close corporations (and in end-games in public corporations) where free exit breaks down, the other rights often prove of little worth. ${ }^{128}$ Finally, at the political level, the ability of corporations to exit any particular state's law virtually eliminates any possibility that states can coerce corporations by law.

The multiple associations of civil society spectacularly avoid most of the problems of majoritarianism and markets discussed above, since exit limits their power of coercion and boundaries are flexible, multiple, and largely defined by current participants. By joining or leaving groups, individuals choose their own boundaries and place their own limits on the power of the majority (or the governing elite).

But pluralistic civil society has problems of its own, parallel perhaps to the market's ever increasing cycle of inequality. First, an organization may be able to free itself from answerability to any external norms or participant support, becoming instead a self-sustaining pot of money employing professionals to promote a set of goals with no one in a position to change or restrain them. A fully funded foundation, thus, may be answerable to no human being at all: each human who works for it may view her role as requiring her to set aside her own beliefs in favor of a fiduciary responsibility to a imagined purpose. ${ }^{129}$ Ordinary publicly traded business corporations are largely

127. On the effects of free exit as a corporate governing system, see Greenwood, Fictional Shareholders, supra note 10, at 1036-45.

128. While individual shareholders have an absolute right of exit, shareholders as a group have no right of exit at all. Accordingly, corporations can often oppress all shareholders more easily than a part of them. Most of corporate law involves these situations, often in end games where shareholders as a group can be exploited because the firm is being sold or going private and the shareholders as a group will no longer be part of the firm. See, e.g., Rauch v. RCA Corp., 861 F.2d 29, 29-32 (2d Cir. 1988) (involving a suit by preferred stockholders who were denied their redemption rights after a de-facto merger); Rabkin v. Philip A. Hunt Chemical Corp., 498 A.2d 1099, 1100-03 (Del. 1985) (involving majority shareholders who accepted a buyout that left minority shareholders with only appraisal rights deemed "fair but not generous"); Weinberger v. UOP, Inc., 457 A.2d 701, 704-06, 711 (Del. 1983) (involving a cash out merger that threatened to eliminate the minority shareholders); Coggins v. New England Patriots Football Club, Inc., 492 N.E.2d 1112, 1116-18 (Mass. 1986) (involving an ousted director who bought a majority of outstanding shares and attempted to freeze out minority shareholders in an attempt to regain control of a company).

129. See, e.g., Henry Hansmann, Why Do Universities Have Endowments?, 19 J. 
similar in that no one in the system has the authority to set the firm's goals. Managers are professionals, entitled only to pursue the corporation's interests as defined by external norms of profitability. Shareholders as voters are a pressure group for a particular understanding of profit, but lack authority or mechanisms for balancing that goal against any conflicting ones. Shareholders, customers, and employees can influence the firm through their market decisions, but like the shareholder electorate, have no way to express multiple roles or value conflicts. ${ }^{130}$

Second, the right of exit is not necessarily enough to free individuals from coercion by their organizations. Much as exit is of little use to shareholders in close corporations-they have the right to sell but no market in which to find a buyer-so too the right of exit may prove useless to people whose lives are bound up in important ways with institutions. We typically view municipal taxes as coercive, although avoiding them is as easy as moving: but moving (literally or figuratively, whether to avoid municipal charges, unpleasant or unfair employers or church oppression) means breaking social ties, creating new friendship and professional networks, uprooting children and other family members, and so on. Exit may come at a high collateral price and seemingly voluntary choices may, just as in the market, be more or less constrained.

Only when exit is reasonably free of collateral consequences is it right to view the coercion problems as solved. A free market in toothpaste, where most consumers can choose to exit existing relationships with virtually no collateral issues at all, is far more likely to be non-coercive than a market in local utilities or even high-priced rentals: one can avoid the water company or entrenched landlords, but only by moving elsewhere.

In short, civil society poses democratic problems principally where the organization is on autopilot and may have impacts on nonmembers (as in the corporate and foundation examples above) or where exit is not readily available, so that groups can impose on their constituents-corporations on shareholders as a group or on immobile employees, churches on dissidents with extensive social ties, and so on.

\section{E. Normative Systems}

Political majoritarianism, the market, and civil society characterized by free exit from a multiplicity of groups each aggregate the opinions and views of their participants. In contrast, the normative

LEGAL STUD. 3, 29-32, 37-39 (1990).

130. Greenwood, Fictional Shareholders, supra note 10, at 1090-93; Greenwood, Essential Speech, supra note 10, at 1067. 
systems-bureaucracies, judiciaries, and similar institutionsoperate quite differently.

\section{Normativity and Deference}

In normatively based structures, professional decision-makers attempt to apply a set of normative values on behalf of clients who for one reason or another are unable to or barred from deciding for themselves. Unlike decision-makers in democratic and market systems, these professionals are expected to set aside their own values to the greatest extent possible. Furthermore, the norms they apply are supposed to be external from the process, not generated by it.

When courts and administrative agencies act as they are supposed to, they apply norms found in the law, created by democratic political processes, or even, as in some contracts disputes, created by the parties to the controversy. What they do not do-in contrast to market or democratic systems-is to apply their own values or aggregate others' views.

Similarly, professionals, such as lawyers, doctors, or corporate managers, seek to find effective ways to reach goals that are set by others, outside of the professional process. Lawyers and doctors, like other members of the free professions, are generally required to take their clients' (and the judicial system's) goals as their own: the professional sets aside her own views as to ends and confines her expertise to means.

Likewise, corporate managers. The ultimate goals of corporations are set entirely outside the corporate decision-making process: corporate managers, when they act as they are supposed to, run the corporation in pursuit of profit maximization. They are not expected to consider alternative or competing goals, nor do they have institutional mechanisms to enable them to do so. Corporate managers have great freedom under the business judgment rule to manage firms as they see fit and there is, of course, a great deal of controversy over how they should see fit. ${ }^{131}$ But no CEO of a publicly traded corporation has ever been heard to say (out loud) that he intends to manage the corporation in the way that will make him feel the happiest, have

131. See, e.g., Shlensky v. Wrigley, 237 N.E.2d 776, 779-80 (Ill. App. Ct. 1968) (leaving the final business decision to the board when the "decision is one properly before directors and the motives alleged in the amended complaint showed no fraud, illegality or conflict of interest in their making of that decision"); Auerbach v. Bennett, 393 N.E.2d 994, 1002-03 (N.Y. 1979) (affirming that a court may investigate the procedural aspects of a board action, but it must leave the substance of business decisions to the board itself); Kamin v. American Express Co., 383 N.Y.S.2d 807, 815 (N.Y. Sup. Ct.) (noting the principle that a court "will not interfere [with a decision delegated to a board] unless a clear case is made out of fraud, oppression, arbitrary action, or breach of trust"), affd, 387 N.Y.S.2d 993 (N.Y. App. Div. 1976). 
the most fun, promote his personal aesthetic or political goals, or even make him richest. Even CEOs who appear to pursuing those goals will always explain that appearances are misleading. Rather, they will defend themselves by claiming they are merely acting in the best interests of the shareholders (or the firm)-doing not what the CEO wants to but what she must. ${ }^{132}$ Like a judge, a CEO is engaged in an interpretative process, not a legislative one: the job is not to choose a goal but to operationalize, implement, and achieve it.

Norms, of course, never are self-applying and usually are controversial. So professionals in normative decision-making structures often, perhaps even always, must define, refine, interpret, explicate, and even transform the norms they are given. But the distinction remains: bureaucrats, judges, and professionals-unlike aggregators-are always directed to attempt to understand the logic of a direction not their own. Professionals help their clients reach the client's goals, not the professional's.

Judges interpret the law; they should not make it (although, of course, outside observers may have trouble telling the difference). When the law is indeterminate or unclear, judges staying within role will attempt to decide what the law is using whatever clues they have to the law's logic, normative demands, or the lawgiver's intentions, not what they want the law to be. For this reason, it is rare indeed to read a judicial opinion saying "I followed my political leanings," let alone "this is what the polls show the majority wants." True, judges and commentators often loudly complain that that is precisely what their opponents are doing, but the charge is always taken to be one of bad faith. That is, it is rare to hear a defense of judges taking on a legislative or voter's role-all sides of our debates agree that that would be wrong. ${ }^{133}$ Our debates are, instead, about how judges can understand, apply, discover, or interpret normsalways located somewhere outside their own preferences-and what to do when, as always, the available norms conflict or are inconsistent.

\section{Polynomic Normativity and its Discontents}

Judges or professionals who do try to set aside their own values often will not succeed. The task may not even be possible in a funda-

132. See, e.g., A.P. Smith Mfg. Co. v. Barlow, 98 A.2d 581, 582-83 (N.J. 1953) (company successfully defended a gift to Princeton on grounds that the contribution was profit maximizing). But see, e.g., Dodge, 170 N.W. at 683-85 (finding breach of duty where $\mathrm{CEO} / \mathrm{majority}$ shareholder asserted right to manage company on behalf of his own vision of the best "industrial system").

133. Sometimes, of course, judges do act in bad faith and do not set aside their personal values in favor of the norms of law. There are dishonest judges as there are dishonest professionals in all fields. 
mental way. The range of reasonable interpretation (and interpretive theories) is usually wide enough that many positions can be competently defended. Good faith would bar consciously choosing among theories based on the results they generate in a particular case-but it cannot bar choosing, even consciously, a theory because of the results it will produce in general (what other basis of choice could there be?).

Consider, for example, the Scalia-kampf in Planned Parenthood of Southeastern Pennsylvania $v$. Casey. ${ }^{134}$ Justice Scalia furiously denounces the joint opinion in that case and, by implication, virtually every justice in the history of the court, for imposing "value judgments and [a] conceal[ed] political choice" in the name of the law. ${ }^{135}$ The opinion draws at least part of its anger from Justice Scalia's perception that his colleagues are insufficiently deferential: as he puts it, "no government official [presumably excluding himself] is 'tempted' to place restraints upon his own freedom of action." ${ }^{136}$ With the bitterness of the radical who has failed to convince his colleagues of the Truth, he complains that the court picks and chooses among its precedents and the available normative principles by personal predilection and leaves lower courts to "give effect to his personal preferences." ${ }^{137}$ That choice, he states, belongs to the states: "A State's choice between two positions on which reasonable people can disagree is constitutional even when (as is often the case) it intrudes upon a 'liberty' in the absolute sense." ${ }^{38}$ Justice Scalia's complaints about particular aspects of the joint opinion may be well taken-in particular, he clearly is correct in rejecting the notion that the Court can resolve controversies in a way that the nation is obligated to accept. But his complaint about the other Justices' imposing their personal predilections is either wrong or proves too much.

On the one hand, Justice Scalia surely is wrong in accusing his colleagues of bad faith; it is that accusation-apparently based on no more than their failure to adopt his preferred interpretive theory or result-that lends the tone of hysteria to his opinion. Though they have chosen to defer to different sources of law than he, their opinions give every indication of an honest attempt to grapple with a difficult legal issue.

On the other hand, Justice Scalia's complaint that the authors of the joint opinion have made a political choice is surely correct. Values do not interpret themselves; nothing in the Constitution necessarily

134. 505 U.S. 833, 999 (1992) (Scalia, J., dissenting).

135. Id. at 983 (Scalia, J., dissenting).

136. Id. at 981 (Scalia, J., dissenting).

137. Id. at 984,992 (Scalia, J., dissenting).

138. Id. at 980 (Scalia, J., dissenting). 
determines the result in this case (or any other case of significance). But there is no escaping that problem. For all of the Justice's bitter language about the failings of his colleagues, he too has exercised choice, as he must, in precisely the same sense that they have. For it must be a result of either his values (which, incidentally, I would assume are not "chosen" in the ordinary sense) or his personal predilections that Justice Scalia has decided to defer to what he calls the "longstanding traditions of American society." 139 Even leaving aside the choices involved in constructing that tradition, it is not the Constitution but his interpretive theory, chosen presumably based on some set of values, that tells him that the Fourteenth Amendment is meant to ratify some existing inequalities and injustices of society. The Amendment bars infringements of liberty without due process of law, violations of equal protection, and protects the privileges and immunities of American citizens. It says nothing about traditions at all. The task of the court is to determine whether state control over a woman's body improperly violates her liberty or equal protection: ${ }^{140}$ merely noting that states have invaded that liberty in the past tells us nothing at all about whether the invasion is permissible in a free society governed by principles of equality and due process. Had no state ever done so, were there no disagreement, the issue would never come before the court.

In all important cases, reasonable arguments can be made for multiple positions. We have a legal tradition that for many years upheld bars on abortion, over the objections of many of us. It often did so in order to vindicate values, such as the health of the mother, some of which are not served by such a ban today. It also did so based on values that even Justice Scalia agrees violate the principles of legal equality and due process today: surely it is not arguable that the married women's property acts or common law notions of married women's loss of legal personality could be upheld today. He would reject one part of the tradition but not the other; others see them as inseparably intertwined.

Traditions only continue when they are weeded and cared for; even Justice Scalia must allow us to discard some elements of our traditions. As Burke taught, traditions are created when people strive to "consider[] their most sacred rights and franchises as an inheritance" even if they are "perhaps not always correct about the pedigree." ${ }^{141}$ Tradition, that is, is an act of the present generation, a

139. Id. (Scalia, J., dissenting).

140. No member of the Court is prepared to hold that the fetus has Constitutional rights. See id. at 869-71 (upholding a woman's right to terminate pregnancy before viability); id. at 913 (Stevens, J., concurring) (detailing the Court's objection to characterizing a fetus as a "person" under the Fourteenth Amendment).

141. BURKE, supra note 8, at 273 (emphasis omitted). 
decision to "claim and assert our liberties as an entailed inheritance .... [which] leaves acquisition free; but it secures what it acquires." ${ }^{142}$ In order to be able to "claim," "acquire," and "consider" our liberties in this way, we - not our ancestors - must be able to distinguish between those privileges we consider advantages and those we would prefer to leave by the wayside of history. ${ }^{143}$ It is that process of evaluation, picking, and choosing-not the tradition itself-that is doing the work. Just as electoral boundaries precede democracy, and market parameters precede efficient allocations, values determine what counts as tradition.

If Justice Scalia means to suggest that there is some alternative to confronting the conflict of values, legal principles, and political ideals implicit in the case, he is simply wrong. No matter how hard we listen, the silent text of the Constitution will never resolve our legal or political dilemmas without interpretation. If he means that the Constitution obviously and clearly grants states the rights to regulate abortion and sexual behavior but not birth control, that equality by itself precludes segregation and affirmative action but not the state's granting to husbands the legal right to control their wives' lives, that the language of the Due Process Clause decides these cases so that any other view of its requirements could only be motivated by bad faith-the position is absurd.

On the other hand, if Justice Scalia means that in all cases in which values conflict or legal materials do not give a single and clear answer to contested problems, courts should defer to contemporary political processes, then his argument undermines the entire process of judicial review and, indeed, perhaps the very notion of law itself. All law involves judges attempting to discern to whom to defer in cases of controversy. Cases only arise when traditions conflict, norms point in different directions, or universally accepted principles (do not kill, hands off my body, equality of individuals, respect for marriage, sanctity of conscience, social control, autonomy, and dependence) resolve issues differently.

Only brute force attempts to rule without offering a normative justification and in the end it always loses: no one is strong enough to rule indefinitely without normative legitimation. The ruled, or the losers, must be persuaded on some level that their situation is justifiable or they will never give up the battle. But norms generate reasonable argument, not the final resolutions which Justice Scalia seems to demand.

This looseness of our normative systems creates a problem that 
might be called the "polynomy problem."144 Collectively and individually, we do not subscribe to a single, internally consistent, normative system. Thus, different experts attempting to work out the implications of the system are likely to come to different conclusions; indeed, even the same expert, Hercules notwithstanding, is unlikely to be able to maintain consistency except at the cost of absurdity. As every lawyer knows, many legal problems can be approached from different angles - and the angle from which you begin the analysis changes the result you reach.

But if reasonably correct normative analysis can reach different results from different starting points, the starting points-the choice of norms or interpretive methods or viewpoints-seem to be determining the results. Just as the boundary problem undermined majoritarianism (because decisions seem to be made by the democratically-arbitrary boundaries rather than by a fixed majority), so too the polynomy problem undermines both professionalism and normative systems. The results of normative analysis depend on the decisionmaker's starting point - which is normatively arbitrary and outside the professional role - rather than on the norms themselves.

A second major problem might be called the "self-interest (or cognitive dissonance) issue." Good faith is unlikely to trump the ordinary workings of the unconscious human brain. Normal cognitive dissonance and self-serving application of flexible norms should assure that judges will often unconsciously choose theories even for their result in particular cases, especially where the result is more salient than its justification. ${ }^{145}$ That, I assume, is why we try to make theories explicit in law schools and demand that judges be explicit about them in decisions-the unconscious works strongest in the dark. ${ }^{146}$ This problem of the unconscious presumably is also the reason why professionalism is not thought to be enough protection in cases of direct self-interest. ${ }^{147}$

144. See Cover, supra note 75 , at 16 (describing polynomic systems).

145. For an example of empirical work supporting the notion that self-interest will affect perceptions of the correct norm to apply, see Linda Babcock \& George Loewenstein, Explaining Bargaining Impasse, in BEHAVIORAL LAW AND ECONOMICS, supra note 96 , at 357 (explaining that where two norms could reasonably be applied, experimental subjects told to imagine that one norm was more in their interest were more likely to feel that that one was correct).

146. We sometimes claim that explicit reasoning improves the quality of decisionmaking even apart from cognitive dissonance issues. But the common law principle that it is the holding, not the rationale, which merits deference points to a certain discomfort with over-rationalization.

147. There are exceptions. In corporate law, for example, self-interest lifts the protection of the Business Judgment Rule, requiring courts to take a closer look. See, e.g., Cinerama Inc. v. Technicolor, Inc., 663 A.2d 1156, 1168 (Del. 1995) (holding that business judgment rule will not be applied where an "interested director controls or domi- 
Normative institutions, then, have at their core fundamental problems, just as the aggregative ones do. Majoritarianism and market can be rendered indeterminate by the boundary problems and theoretically indefensible by the might-does-not-make-right problem. Polynomy and cognitive dissonance are parallel threats to the determinacy and defensibility of normative institutions.

The proper methods of judicial decision-making are, of course, the subject of a vast and controversial literature. But nearly everyone - rule-bound positivists, diviners of original intent, seekers of Dworkinian integrity, and searchers for natural law or cultural values agrees that judges act illegitimately if they simply decide as if they were voters. ${ }^{148}$ The controversy is over where judges should find the values they should apply and what to do with conflicts; there is general agreement that the values should be somewhere out there, not in the judge's own politics.

Modern jurisprudential debate centers on the issue of how judges should deal with normative multiplicity. In constitutional law, the Supreme Court must interpret a constitution that is always ambiguous (at least, unambiguous issues never reach the Court). Professionalism and the ethos of normativity require that they do so by setting aside their own values and understanding those of the Constitution itself. But the Constitution's values are self-contradictory: it endorses both democracy and normativity, majority rule and countermajoritarian limitations, slavery in its origins and anti-slavery in its development, and federalist centralism and anti-federalist decentralization.

Like all of our law, the Constitution invokes extra-textual notions of right and wrong that are themselves multiple and inconsistent. We believe that right and wrong have to do both with intention and consequences, that desert and merit are determined both by effort and by results, and that meaning stems from both subjective intention and objective understanding. But those core values contradict each other, and they do so non-hierarchally: "those who do not work neither shall they eat" is just as fundamental as "share and share alike." In the efflorescence of our normative systems, problems arise precisely because competent normative defenses can be made of

nates the board as a whole or fail[s] to disclose his interest"); Sinclair Oil Corp., 280 A.2d at 721-22 (holding that actions of the dominant shareholder engaged in selfdealing must be tested against the "entire fairness" standard). Nonetheless, courts remain quite deferential towards self-interested transactions, looking more for evidence of theft than unconscious bias. See, e.g., Paramount Communications, Inc., 571 A.2d at 1151-53 (readily accepting claims that apparently self-interested transaction was motivated by concern for "Time Culture").

148. Some positivist theorists have claimed that judges sometimes have no choice but to legislate. But even - or especially - they reject judicial legislation in all other circumstances. 
many approaches and multiple results.

Often, the Constitutional text identifies issues rather than expressing a particular value. Thus, the First Amendment's Free Speech and Religion Clauses ${ }^{149}$ and the Fourteenth Amendment's Due Process and Equal Protection Clause ${ }^{150}$ indicate the centrality of those struggles without resolving any particular case. Thus, if the First Amendment means anything at all, one might think, it at least means that criticism of the government and its policies is protected; yet the Sedition Act of 1798 and the decisions in Debs v. United States and Rust v. Sullivan each demonstrate that even this core of meaning has been and remains deeply contested. ${ }^{151}$ Core meanings are regularly disputed: does the Fourteenth Amendment protect African-Americans, citizens, or corporations, ${ }^{152}$ does the Establishment Clause bar the government from celebrating religious holidays or forcing citizens to do so; ${ }^{153}$ and so on. And that is without entering the difficult issues, such as the meaning of the Contract, Commerce or Due Process Clauses, let alone the Direct Taxes Clause, Second, Tenth or Eleventh Amendments, or instances such as the Declaration of War Clause, where we seem to have clear consensus that the words, whatever they mean, do not mean what they say.

In each of these cases, the norm of deference is in trouble, for the

149. U.S. CONST amend I.

150. U.S. CONST amend XIV \& 1 .

151. Sedition Act, ch. 73, 1 Stat. 596 (1798); Debs v. United States, 249 U.S. 211, 217 (1919) (upholding conviction based on criticism of WWI war effort); Rust v. Sullivan, 500 U.S. 173, 192-94 (1991) (upholding governmental regulation prohibiting government funded doctors from recommending abortion). There may now be near universal agreement that the Sedition Act was unconstitutional, but there is clearly no agreement about the more recent cases. Rust, thus, is easily defensible within current doctrine and is as easily attacked: it split the Court and the commentators about evenly.

152. Compare Slaughterhouse Cases, 83 U.S. (16 Wall.) 36, 68-69, 72 (holding that it is "free from doubt" that the primary purpose of the Fourteenth Amendment is to protect African-Americans from the states), with Adarand Constructors, Inc. v. Pena, 515 U.S. 200, 213-18 (1995) (holding that the Fifth Amendment restricts the federal government to same degree that the Fourteenth restricts states, and that the Fourteenth Amendment restricts government from seeking either to aid African-Americans or to hurt them, if racial classifications are used), and Santa Clara County v. Southern Pac. Ry. Co., 118 U.S. 394, 394 (1886) (acknowledging in the statement of facts, without explanation, that the Fourteenth Amendment protects corporations and not merely human beings).

153. E.g., Lynch v. Donnelly, 465 U.S. 668,680 (1984) (holding that government unit may, under specified circumstances, erect a Christmas crèche); McGowan v. Maryland, 366 U.S. 420, 443-45 (1961) (holding that government may require citizens to observe Christian Sabbath). In each of these cases, the Court held that religious observances were secular, thus allowing the state to fund or coerce religious acts: seemingly the core of the Establishment Clause. See Lynch, 465 U.S. at 680; McGowan, 366 U.S. at $443-45,452$. 
same reason that the boundary problem threatens majoritarianism. If the judge can (or must) decide to what to defer, that pre-deference choice is doing the work. Choosing to whom to defer can no more be deferential than drawing the boundaries that will determine the majority can be majoritarian. Rather, the choice of norm is precisely the non-professional, non-judicial act that judges are not supposed to be engaging in.

Faced with this polynomy dilemma, some theorists attempt to push back the deference, suggesting that judges defer in their choice of norm (much as some theorists try to offer majoritarian theories of boundary setting or Coase attempts a market theory of market boundaries). But this is not going to work. The decision to defer to "plain meaning," "legislative intent," or "best understanding," process-based concerns, or substantive values is a decision, not deference. Once any norm is contested, the judge must decide to what to defer. To be deferential, that decision must be based on an underlying interpretive theory. But the underlying interpretive theory must itself must be chosen before deference can begin. There is no undisputed resting point at the bottom: as William James's interlocutor is said to have said, it's "turtles all the way down."154

Normative supremacy theories, in short, are internally inconsistent in much the same way that market supremacy and legislative supremacy theories are. Majoritarianism only works within boundaries set by non-majoritarian means; markets only allocate within initial rights allocations and terms of trade that are set by non-market means; judicial deference-or professional norm interpretation generally-is only determinate, if at all, within a interpretative framework that itself can not be discovered by deferential interpretation.

Similarly, other common attempts to solve the boundary problem of judicial deference do not work. For example, on this analysis, interpretive theories that emphasize fidelity to the intent or purpose of the legislature (understood as something other than the meaning of the text itself) probably are best re-understood as claims that the judiciary ought to see the legislature as its client, rather than taking the law as its guiding norm. Where the law is unclear, as the positivists put it, judges ought to imagine what the legislator would do in the circumstances and act on behalf of the legislator as a good professional. But if this means deferring to the individuals who wrote the law-attempting to reconstruct what they would have done in the circumstances, or imagining how the "Founders" would have, as legislators, decided the issue before the court, as historically oriented

154. See Jed Handelsman Shugerman, Book Note, Rights Revolutions and CounterRevolutions, YALE J.L. \& HUMAN. 531, 534 \& n.8 (2001) (describing the origins of the story). 
constitutional law often seems to suggest-it is democratically indefensible. The legislature in a modern democracy is only a representative of the people, not a sovereign, and its intentions, unless they are embodied in duly passed statutes, should have no status at all. Judges who defer to legislatures instead of legislation are deferring indeed, but to an illegitimate authority. Relying on the purpose or intent of the legislature (or Founders) elevates our representatives to a position they should not have in a constitutional regime, replacing the rule of law with the rule of men. Thus, even were the philosophical difficulties of ascribing an intention or purpose to a collective body overcome, this theory would be unacceptable.

A different variation of the counter-majoritarian claim avoids this anti-democratic problem at the cost of nihilism. Some of the counter-majoritarianists seem to contend that judges ought to defer to the legislature precisely because normative theories are incoherent or the law reflects no norms other than an arbitrary will of the sovereign. The power of judicial deference is so strong that even deference to undemocratic, unanswerable, and possibly long obsolete "intentions" still seems preferable to no deference at all. But the argument assumes too much: if norms do not exist, then why follow a norm of judicial deference to legislatures? One must have a normative theory justifying majoritarian supremacy in the face of the boundary and majoritarian problems and we do not; indeed, this critique appears to claim that we cannot.

Relatedly, precedent cannot solve the problem. A judge who chooses to follow precedent is deferring-she is allowing an earlier judge's decision to trump her own best judgment. But as a general principle, this is utterly unsatisfactory: it means that each issue is decided by the first judge to consider it, precisely the opposite of the considered, repeated approval under many different circumstances that would make deference sensible. Deferring to the judgment of others makes sense only if the others are not deferring; precedent is defensible precisely when independent thinkers set the precedents. ${ }^{155}$

For present purposes, two points are important. First, all professional and normative processes view themselves as focused on means rather than ends. The norm (or the client) sets the end; the professional seeks to reach it. This means, of course, that the professional's job can be no better than the norm (or client) served. And second, normative decision-makers, such as judges, ask themselves (or should ask themselves) a distinctive set of questions-not what is best for society (as a statesman should) or what is my interest or the 
interest of my constituents (as voters or politicians, respectively, may) but, rather, what is the meaning of the norm I am directed to apply. A judge, that is, approaches a tax code or the Constitution not by asking what law would make our society a better place to live (objectively or from some individual or group's perspective), but by asking what the meaning is of a code provision, a Constitutional clause, or even "right," "justice," or "law" itself. Though judges no doubt will be guided in their choices within an inherently contradictory and confusing set of norms by some sense of what is good for society, they are directed to put that aside, to the extent they can, and focus instead on the interpretive issue: how can we best make sense of the language in front of us. That, presumably, is why otherwise intelligent and sensible people can be heard to say that for the sake of consistency, in furtherance of the rule of law, they must issue decisions that they believe are (and believe others will agree are) wrong as a matter of social policy.

\section{Normative and Aggregative Decision-Making Processes Compared}

Aggregative processes derive their legitimacy from the people they represent and the accuracy with which they reflect their views. It is a valid internal criticism of a market to say that it distorts the preferences of customers or of a legislative process that it does not reflect the will of the majority. Thus, Arrow's Voting Paradox, the Prisoner's Dilemma and related game theory problems, ${ }^{156}$ the boundary problems discussed above, the theory of economic monopoly power, and Kahneman and Tversky's systematic cognitive biases ${ }^{167}$ are each criticisms of the ability of specific aggregative systems to reflect correctly the underlying views being aggregated. Perhaps the same is true even of more radical critiques of the very notion that people have coherent systematic sets of preferences that can be treated as existing independently of the choices with which they are presented: Arrow's voting paradox on the individual level.

In contrast, complaints that the customers or the voters do not want the right things are different: those claims step outside of the

156. See, e.g., Arrow, supra note 83, at 614-16; Saul Levmore, Book Review Colloquium: Public Choice and Constitutional Law, The Public Choice Threat, 67 U. CHI. L. REv. 941, 958-66 (2000) (describing Arrow's Impossibility Theorem or Voters Paradox, the Prisoners Dilemma, other public choice theories, and their impact on legal theory); Richard F. Pildes \& Elizabeth S. Anderson, Slinging Arrows at Democracy: Social Choice Theory, Value Pluralism, and Politics, 90 CoLuM. L. REv. 2121, 2124-25 (1990) (describing Arrow's Paradox and its importance).

157. See, e.g., Amos Tversky \& Daniel Kahneman, Judgment under Uncertainty: Heurostics and Biases, 185 SCIENCE 1124 (1974); Daniel Kahneman et al., Anomalies: The Endowment Effect, Loss Aversion and Status Quo Bias, 5 J. EcoN. PERSPECT. 193 (1991). 
aggregative system, because they question not whether it can function or is functioning as it is expected to, but rather whether it should be allowed to function, a normative rather than a positive question. Those who demand that majoritarianism give way to justice or individual rights, who call their opponents "paternalists" or who base their own views on theories of false consciousness are debating about the legitimacy of aggregation theories as decisionmaking systems. These arguments are about whether we ought to aggregate at all rather than about whether particular forms of aggregation properly reflect the underlying views.

Normative processes, unlike aggregative ones, derive their legitimacy from the norm they enforce, not from the people whose views they represent. A judge is legitimate because she applies a legitimate law, not because she was elected in a fair election.

Thus, normative processes have two foundational requirements: first, that participants apply the norm and not (as critics often accuse them of doing) ignore it, replace it, or substitute their own values; and second, that the norm itself is legitimate. Normative processes can never be better than the norm they apply. If the law is illegitimate, faithfully following it is no virtue: applying an evil rule consistently only makes one good at evil. ${ }^{158}$

\section{a. To What to Defer?}

In a world in which norms do not grow on trees, judges are understandably anxious to find norms wherever they can. ${ }^{159}$ Unsatisfactory as ancient or non-majoritarian statutes, written constitutions, social contract theory, non-Article $\mathrm{V}$ amendments, or common law precedent may be on democratic grounds, each supplies a norm clearly not of the judge's own invention.

Not one of these common sources of legal authority can stand up to even a minimally serious majoritarian critique. Article $\mathrm{V}$ amendments passed by long dead legislators (even were they, counterfactually, democratically elected at the time) are no more majoritarian than non-Article $\mathrm{V}$ amendments or even pure judicial glosses, even if they are easier for text-centered graphophiles to accept. De Maistre was surely correct to make fun of Thomas Paine for claiming that a constitution does not exist so long as one can not put it in one's pocket: ${ }^{160}$ it is not the words on the paper but the understanding in

158. See, e.g., Hannah AREndt, Eichmann In Jerusalem: A Report on the BaNALITY OF EVIL 253-279 (Penguin Books Ltd. 1977) (1963) (stating that Eichmann defended his actions as in conformity with the norms of his role: he murdered without making personal distinctions).

159. See Daniel J.H. Greenwood, Four Views of Precedent (draft on file with the author).

160. MAISTRE, supra note 6, at 13. 
the hearts of the people that is the law.

In fact, judges rarely differentiate between these sources of law and more clearly democratic ones on the basis of democratic credentials. This suggests that judicial deference has little to do with the "counter-majoritarian difficulty" at all. Instead, judicial deference is an essential part of the profession of judging: judges act as judges only if they apply an external norm.

Judges defer to these non-democratic norms in part because they have nothing better to which to defer. Simply doing what seems right would, in the absence of a theory of rightness to which they could defer, be an out-of-role and unprofessional act. Failing to defer would not necessarily be undemocratic-a modern judge acting as a legislator surely has as good majoritarian credentials as, for example, the parliament that passed the statute of frauds. In actuality, neither one has much of a claim to reflect modern public opinion, but surely the judge's is better.

\section{b. Why Defer?}

If deference is fundamental to judging, the question still remains: why judge at all? Why not follow the nihilist logic of the counter-majoritarian difficulty to its fullest, eliminate the judiciary altogether and rule by aggregation rather than norms? The answer presumably lies in large part in practicality-aggregative institutions are poorly equipped to actually administer anything. But it also lies in the tension that animates this Article: judicial normativity may be fundamentally flawed, but it is also absolutely essential. Without norms to restrain or guide them, the aggregative institutions are incoherent, indeterminate, and most likely unjust. There is nothing particularly attractive about rule of the majority if the majority is just a mob.

Moreover, if the majority is the only source of legitimate rule, why should it ever be constrained by what some other (earlier) majority has done? Not only would the British commitment to parliamentary supremacy be clearly correct, but it would not go nearly far enough. As Burke correctly noted, the logic of the majoritarian position requires that all the inertia of the past ought to be swept away: an extraordinarily hubristic position, not to mention rather destabilizing. ${ }^{162}$

161. See BURKE, supra note 8, at 249 (emphasizing the unpleasant aspects of a fully rational approach to politics). In Burke's view, the alternative to irrational deference to the past is worse:

On the scheme of this barbarous philosophy ... laws are to be supported only by their own terrors and by the concern which each individual may find in them from his own private speculations or can spare to them from his own private interests. In the groves of their academy, at the end of every vista, 
The aggregative systems, left to their own, are highly susceptible to fads and herd-like behavior. Markets notoriously suffer from booms and busts, pet rocks and dot.com collapses, hit movies and bombs. Majoritarian politics show the same radical swings in fortune and poll results. ${ }^{162}$ Judges are unlikely to be any more immune to fads than the rest of us. But judicial deference, including deference to precedent, focuses judicial attention on different information than aggregative players: judges look not at their contemporaries, but their predecessors. This should make them a historicizing, conservative counterbalance to the sometimes-disturbing radicalism of markets and the fads of politics.

Attractive democracies attempt to live by justice and with some respect for tradition, not just by majority rule or market survival. Justice is a norm, to be developed, interpreted, explained, and debated, with decision by a vote of judges or legislatures or administrative committees, but with the process far more important than result, and with interpretive claims (what does justice demand) more important than prudential ones (what would be good for us).

Judges must listen and think about norms not their own. They do not (often or competently) engage in political-philosophical speculation. ${ }^{163}$ But they ask a fundamentally different question than the one asked by legislators: not what do my constituents want, or even what might solve the problems before me, but what do the norms of our legal system require. If the system works, as it sometimes does, judges should be interpreting the legal norms in light of the underlying legitimacy of the law: what would our system look like if it were

you see nothing but the gallows.

Id. at 333.

162. On the fads and bubbles of aggregative processes, see ROBERT J. SHILLER, MARKET VOLATILITY 345-48 (1989) (arguing that markets display far more volatility than expected) (citing Vernon L. Smith, et al., Bubbles, Crashes, and Endogenous Ex. pectations in Experimental Spot Asset Markets, 56 ECONOMETRICA 1119-51 (1988) (reporting an experiment in which traders were told the true future probability distribution of dividends on assets (thus, price changes could not be result of new or unforeseen information) and nonetheless frequent bubbles occurred)); J. Bradford De Long, et al., Positive Feedback Investment Strategies and Destabilizing Rational Speculation, 45 J. FIN. 379, 381-84 (1990) (describing how feedback loops lead to bubbles); Fischer Black, Presidential Address: Noise, 41 J. FIN. 529, 537-38 (1986) (finding that changes and uncertainty in technologies and tastes can create "noise" that distorts business cycles and economic markets); Andrei Shleifer \& Lawrence H. Summers, The Noise Trader Approach to Finance, 4 J. ECON. PERSP. 19, 29 (1990); Rational Economic Man The Human Factor, ECONOMIST, Dec. 24, 1994, at 90 (describing economic models demonstrating that fads and bubbles can result from use of "rules of thumbs" or rational heuristics); Yes, Ten Million People Can Be Wrong, ECONOMIST, Feb. 19, 1994, at 81 (describing how a rational information cascade can cause herd-like behavior).

163. See Michael W. McConnell, The Role of Democratic Politics in Transforming Moral Conventions into Law, 98 YALE L.J. 1501, 1536 (1989) (recognizing that judges are not philosophers). 
seeking to be legitimate, decent, right, and had these legal materials at its hand. ${ }^{164}$ That is the distinctive judicial contribution to the puzzle of democracy, and the only stance that leaves the judge with something to contribute rather than merely a servant to others. It is a deference to both the legal materials and a broader moral and political culture that is itself contradictory and inconsistent.

Normative polynomy is inescapable and foundational. If we had a single, coherent, consistent understanding of the requirements of justice, that understanding would bind us in all circumstances. It can never be just to do what we know is unjust. So, we might reasonably turn over all elements of government, or at least the outer limits that are defined by justice, to experts in articulating the agreed-upon norms. That is the attraction of the classical social contract theories: no just state could act in such a way (claims the author) or any just state would act in this way. If the claim of justice were so clear, democracy, market and civil society alike would be bound, for we already would know their limits. The aggregative systems would be firmly fenced by the purely hypothetical debates of the original position; normative interpreters would be supreme. But that is the fantasy of manna at Sinai, which each collected according to his ability, and his need, and his desert, and in equal amounts-not the world we live in. ${ }^{165}$ In our world norms conflict, and normative resolutions are always contested and never final.

The nihilists are also wrong. Just because we can articulate different theories of what is right, and sometimes even convince each other that red is blue, we are not left without norms altogether. ${ }^{166}$ But because the norms are not definitive, we cannot leave them to the experts. The debate over what kind of society to be, what the demands of right, justice or law are, must be central to our politics; we need normative analysis as well as aggregative.

\section{Multiple Decision-MaKING STRUCTURES IN AN ORDERED DEMOCRACY}

Each of the aggregative and normative decision-making proce-

164. See, e.g., Frederick Douglass, The Constitution of the United States: Is it ProSlavery or Anti-Slavery, in 2 LIFE \& WRITINGS OF FREDERICK DOUGLASS 467-80 (P. Foner ed., 1950) ("Where a law is susceptible of two meanings, the one making it accomplish an innocent purpose, and the other making it accomplish a wicked purpose, we must in all cases adopt that which makes it accomplish an innocent purpose.").

165. See discussion supra notes 58-61 and accompanying text.

166. See, e.g., Arthur Allen Leff, Unspeakable Ethics, Unnatural Law 1979 DUKE L.J. 1229, 1248-49 (1979) (arguing that even without moral certainty, and in the absence of clear constitutional direction, we can know that murdering babies is wrong); Greenwood, Akhnai, supra note 45 , at $345-46$ (considering the problem of morality in the face of a silent God). 
dures we have discussed is an attempt to embody the partnership ideal of democracy. As we have seen, each has serious flaws. ${ }^{167}$ All of these decision-making structures will be present in a modern ordered democracy. Nor are these the only leading decision-making methods. Lottery is another, which we use for appointing jurors and selecting judges for particular cases. ${ }^{168}$ Queuing, or first-come first-served, aggregates views and allocates existing stocks in a manner structurally similar to markets-to the highest bidder-although without the socially helpful incentives to producers to increase production. Public opinion and gossip-social pressure not exercised through formal institutional structures-are extraordinarily important (and, despite their absence from modern political theory, often as coercive as many governmental entities), both as aggregative systems and through their influence on normative interpretation. And, of course, each of these legitimate systems may be distorted or caricatured, for example by bribery, or by improper interventions such as when business corporations attempt to distort public opinion, normative interpretation, or aggregative processes by lobbying, repeat litigation, or advertising. ${ }^{169}$

As we have seen, each of the available decision-making methods has characteristic strengths and weaknesses. It follows that decent societies will have an irreducible conflict among them. If any one system is able to exclude the others, its injustices will quickly become obvious and the society will cease to be attractive. Good societies will use multiple decision-making systems and will often have conflicts over the appropriate reach of each. Nonetheless, it can often be said that one system ought to be determinative: that is, we may be able to determine that one system ought to decide when it is appropriate for other systems to decide.

We must, then, separate two issues: which decision-making system will decide any particular issue (which might be referred to as the division of powers issue), and the meta-issue of which system decides which system decides (the meta-issue). Both the division of powers issue and the meta-issue are procedural questions separate, of course, from the ultimate substantive question of what the decision-maker ought to decide.

Our constitutional system is founded on the notion that ultimately the people, deciding by majoritarian principles within the political boundaries of the United States but acting under the guidance of normative principles of justice, decide our form of governance. Ac-

167. See discussion supra Parts III.B-E.

168. See supra notes 46-47 and accompanying text for a discussion of lottery as a democratic alternative to majoritarianism.

169. See Greenwood, Essential Speech, supra note 10, at 1066-70. 
cording to the Constitution, "[w]e the people" established the constitution, and "we the people" reserve the ultimate right to change it. ${ }^{170}$ Of course, we did nothing of the sort: we weren't born (and neither did the people of 1789: most of them were disenfranchised). But the myth of "we the people" does show the normative system presenting itself as ultimately answerable to and legitimized by the majoritarian system, not the other way around. Thus, the Constitution's ultimate answer to the meta-issue is that the people (meaning, in our nonnationalist state, the citizenry) decide by majoritarian means (although not necessarily through ordinary political institutions). ${ }^{171}$

In contrast, many liberal political theories and associated theories of constitutional law place the normative system foremost. On this view, democracy is legitimate because, and only to the extent that, social contract or another political theory demonstrates that it is just (or economic theory demonstrates that it is efficient). Should the democratic system attempt to step beyond these bounds (for example, by infringing on fundamental rights or market freedom), it loses its legitimacy. For this reason, in Locke, Rawls and Posner, democracy seems to be only a contingent value. ${ }^{172}$ Similarly, some versions of traditional Jewish law justify democracy because it is authorized in the normative law. On this view, the Torah/constitution determines when democracy is appropriate, not the reverse. ${ }^{173}$

Although similar claims are sometimes made about American constitutionalism, I take it that the dominant legal view is that the source of our constitutional norms, for better or worse, is whatever "we the people" acting as sovereign ordain. Ours is a positivist system, not a normatively based one, at least to that extent. ${ }^{174}$

170. U.S. CONST. pmbl.

171. For a general discussion, see Akhil Amar's work on the constitutional convention in AKHIL AMAR, THE BILL OF RIGHTS (1998).

172. E.g., LOCKE, supra note 6, at 75-76 (§§ 198-99), 78 ( $\$ 201$ ); RAWLS, supra note 2, at 3-6; Richard A. Posner, Forum, Dworkin, Polemics and the Clinton Impeachment Controversy, 94 Nw. U. L. REv. 1023, 1046 (2000).

173. See Greenwood, Akhnai, supra note 45, for a discussion of one place where the Torah is understood to authorize majoritarian procedures. The matter is not entirely clear, however. Another view bases the authority of the normative text itself in its acceptance by the people at Sinai. On this view, which I also find in the Akhnai texts, Jewish law is closer to American constitutionalism, requiring both consent of the people and normative authority for legitimacy. But see Suzanne Last Stone, In Pursuit of the Counter-Text: The Turn to the Jewish Legal Model in Contemporary American Legal Theory, 106 HARV. L. REV. 813 (1993) (arguing that Jewish law is not comparable to secular law).

174. Other systems have different ultimate meta-decisors: for example, more nationalist systems than ours give some authority to the "people" understood as a cultural national body that may not be precisely congruent with the political citizenry. See, e.g., H.C. 72/62, Rufeisen v. Minister of the Interior, 16(4) P.D. 2428 (1962), translated in SELECTED JUdGMENTS OF THE SuPREME COURT OF ISRAEl (SPECIAL VOlume) 
At the same time, in exercising that right, "we the people"-both the authors of the constitution and political actors today-specifically invoke external normative principles to justify their/our actions. Our Constitution was enacted in accordance with the precepts of political science in order to "form a more perfect [u]nion," and it assures "due process," "equal protection," and other rights not enumerated thereunder. ${ }^{175}$

This dual origin, based both in the positive will of the people and the norms invoked by their will, creates the background for our great constitutional controversies in the Supreme Court. The Court, which is a normative body seeking to interpret an externally created set of norms, is invited to view the Constitution as a supreme norm, superior to current legislation despite its democratic inferiority. ${ }^{176}$ In turn, that document itself points to normative sources outside the democratic process.

The Court, as a rule, has taken the view that ordinarily it gets to decide when normative processes (judicial review) apply and when democratic (legislative) processes will make the decision. It angrily rejects Congressional assertions of the meta-supremacy of Congressional democratic processes over judicial normative ones. ${ }^{177}$ Speaking generally, the Court's view is that the meaning of the Constitution is a normative issue, not an aggregative or political one, and accordingly it is the Court, not the Congress, which is entitled to have the final word on the meaning of the Constitution.

1, 11-12, 20-21, 32-33 (Asher F. Landau \& Peter Elman eds., 1971) (the "Brother Daniel" Case) (relying on common usage of, inter-alia, non-Israeli Jews in determining meaning of "Jewish" in Israeli legislation).

175. U.S. CONST. pmbl., amend V, amend XIV, amend IX.

176. The Constitution, as amended, may be more democratic than the legislature to the extent that it reflects a period of heightened political participation. See BRUCE ACKerman, We The PeOPle 37-39, 56-57 (1991) [hereinafter ACKERMaN, We The PeoPLE]. However, at least when the heightened political action was by long dead citizens operating under restricted franchises and the legislation in question is recent and controversial, heightened political awareness does not seem, by itself, enough to justify a purely democratic defense of judicial review. A recent flag burning act, religious freedom protection act, welfare reform act, gun control law, crime control/preventive detention/surveillance measure, or similar hotly fought controversial statute clearly has greater claims to reflect the acts of a current majority than the eighteenth or nineteenth century Constitutional provisions that may make it legally questionable, even if those provisions are read in light of a half-century old constitutional revolution.

177. See, e.g., City of Boerne v. Flores, 521 U.S. 507, 519 (1997) (rejecting Congressional role in interpreting the First Amendment stating that Congress' power to "enforce" the Fourteenth Amendment "follows" from the Court's holdings but does not include "the power to determine what constitutes a constitutional violation"); Planned Parenthood of S. Pa. v. Casey, 505 U.S. 833, 867 (1992) (apparently contending that judicial decisions may require "contending sides of a national controversy to end their national division by accepting a common mandate rooted in the [Court's understanding of the] Constitution"). 
But the Court accepts various exceptions where it acknowledges the primacy of the democratic process. First, the Court has carved out large substantive areas, often labeled political questions, where it declines to review (or to review seriously) Congressional decisions: most foreign policy, immigration law, the Republican Form of Government clause, the principle of delegated powers (usually). ${ }^{178}$ For example, it is virtually inconceivable that the Court would seriously question whether the existence of the Pentagon is compatible with the No Standing Army Clause, whether the Federal Reserve System or Medicare fit within the delegated powers, or if the SEC's prior restraint system is compatible with the First Amendment. Perhaps most significantly, the Court accepts that the Congress can set the Court's jurisdiction and that the Congress and the states or the people can amend the Constitution to change the norms the Court must apply.$^{179}$ But this only reflects the larger controversy: deference alone is not enough to tell the Court when it must defer to (its own) understanding of the Constitution, when to (another institution's) understanding of the Constitution, and when to another institution's actions without specific regard to the Constitution. Nor can it tell us when we should defer to the Court's understanding of when it should defer, and so on.

The Court and commentators debate the extent to which the norms of the Constitution may be invoked to overturn decisions of the Congress and the Executive-as well as, and more controversially, what those norms are, where they can be found, and whether

178. See, e.g., United States v. Morrison, 529 U.S. 598, 617-18 (2000) (holding the VAWA to be beyond Congress's Commerce Clause powers); United States v. Lopez, 514 U.S. 549, 567-68 (1995) (resurrecting the long-dead doctrine that some actions are beyond Commerce Power); Wickard v. Filburn, 317 U.S. 111, 125 (1942) (holding that even farmer's growing of crop for personal use affected interstate commerce and was therefore within Congressional power to regulate). But see, e.g., Morrison, 529 U.S. at 628-30 (Souter, J., dissenting) (arguing that Commerce Power is virtually nonjusticiable).

179. Not all commentators fully accept this view, however. A non-trivial strand of American thought assumes that the legitimacy of Constitutional government lies in the congruence of the substantive commands of the Constitution with the external norms of justice. Were the Constitution to clearly contradict the requirements of justice, this view will either conclude that justice prevails anyway or reject the legitimacy of the entire document. See, e.g., ROBERT M. COVER, JUSTICE ACCUSED: ANTISLAVERY AND THE JUDICIAL PROCESS 154 (1975) (discussing the Garrisonian movement and its opponents). For an example of a similar conflict in a very different legal system, consider the Talmudic debate on the Levitical commandment to execute a stubborn and rebellious child: the rabbis conclude that the text cannot mean what it appears to say, presumably because a just God would not enact an unjust rule. BABYLONIAN TALMUD, Sanhedrin $68 \mathrm{~b}-71 \mathrm{a}$ (finding that "there never has been and there never will be a stubborn and rebellious son"). In each case, the primary norm is justice: if ordinary political or interpretive processes generate an unjust result, these commentators reject the process and unjust result, not the requirements of justice. 
they derive ultimately from the not-very-democratic will of the various pretenders to being the "Founders," from the more democratic will of the current generation, from normative systems endorsed by one or the other of those groups, or from another source such as natural law or theories of justice.

My own view is that as between majoritarian and normative systems, American democracy ultimately demands a dualistic legitimacy: that the people, determining their decisions through majoritarian procedures, apply an external norm of justice and not merely enact their preferences. That is, unless the law is both just and democratic Americans routinely view it as of doubtful legitimacy. ${ }^{180} \mathrm{But}$ I am not prepared to defend that view further within the confines of this Article.

As between those systems and the market, the answer is clearer. At least since the rejection of Lochner, Americans and the Court alike largely have agreed that the market does not have a meta-claim to preeminence. ${ }^{181}$ Markets are useful, indeed essential, parts of our freedom, but the decision of when to use them, how to manipulate them, and when to reject the results they produce (or would produce under some different background conditions) is the quintessential political decision. The majoritarian democratic process decides when to abstain, when to make space for markets, and when to intervene.

The claim is not that majority rule is superior to markets in any particular decision. Choosing breakfast cereals by majority vote has been tried, and it failed. Rather, it is a meta-claim: when we argue about the line between markets and majoritarianism, the argument is-and should be-directed to majoritarian processes, not to market ones (or judicial interpretation of the due process clause). We do not-or should not-put the issue up for auction, we instead put it up for a vote. The vote may well and often does determine that democracy should retreat to make way for more individual decisionmaking, whether market-based or through civil society's entrance and exit options. But it is a collective political decision whether to do that or not.

Lochnerism, in contrast, viewed the line-drawing issue as a nor-

180. See TOCQUEvILLE, supra note 117, at 262-76 (vol. I, pt. II, ch. VIII) (arguing that American democracy is particularly subject to the problem of tyranny of the majority).

181. Compare Lochner v. New York, 198 U.S. 45, 53 (1905) ("The general right to make a contract in relation to [a person's] business is part of the liberty of the individual protected by the 14th amendment of the Federal constitution ...."), overruled in part by Day-Brite Lighting Inc. v. Missouri, 342 U.S. 421 (1952), with Unites States v. Carolene Products Co., 304 U.S. 144, 153 n.4 (1938) ("There may be a narrower scope for operation of the presumption of constitutionality when legislation appears on its face to be within a specific prohibition of the Constitution ...."). 
mative one, to be determined in the first instance by the Court based on its understanding of the norms implicit in the Constitution. ${ }^{182}$ Only constitutional majorities, not legislative ones, could override the judicially interpreted norm. But even the Lochnerists rejected the notion that the market should decide its own boundaries, proximately or ultimately. Freedom of contract could not be sold.

As between the political systems and civil society or even civil society and the economic marketplace, the answer is less clear. One reading of the First Amendment is that it privileges civil society in exactly the way that Lochner contended the Due Process Clause privileged the market. ${ }^{183}$ This is why the First Amendment's increasing reach into economic relations is so dangerous: modern First Amendment doctrine does not distinguish between civil society and market relations, extending to the latter Lochneresque protections that are entirely inappropriate. In both civil society and market, we must worry, however, about the Court attempting to structure social relations by interpreting legal norms that are neither robust nor flexible enough to meet the need. ${ }^{184}$

\section{The Division of Powers After the Collapse of the LAW/POLITICS DisTINCTION}

Montesquieu described the principles of separation of powers and checks and balances two and a half centuries ago. ${ }^{185}$ Tocqueville pointed out the importance of civil society almost as long ago. ${ }^{186} \mathrm{Re}-$ hashing old ground perhaps requires some defense.

Much legal dispute involves setting the boundaries of the different decision-making procedures: who decides, rather than what should be decided. The issue then is distinguishing the proper realm of judicial decisions from democratic, political or bureaucratic ones, and the realm of governmental decision from market and civil society authority. The distinctively modern form of the inquiry must acknowledge that we, more than our predecessors, are haunted by the malleability of the boundaries between the different types of decisions.

\section{A. The Law/Politics Distinction}

Modern constitutional theory, and legal theory generally, has

182. See, e.g., Lochner, 198 U.S. at 53.

183. Id. at 53, 63-64.

184. For further discussion, see Daniel J.H. Greenwood, First Amendment Imperialism, 1999 UTAH L. Rev. 659, 664-65 (1999).

185. MONTESQUIEU, supra note 47 , at 201-13 (bk. XI, ch. VI).

186. TOCQUEVILLE, supra note 117, at 189-95 (vol. I, pt. II, ch. IV), 246-58 (vol. I, pt. II, ch. VII), 520-24 (vol. II, pt. II, ch. VII). 
suffered great anxiety over the distinction between law and politics. Judges do not derive their decisions by logical deduction or applying neutral legal reasoning to preexisting legal principles. So much we have taught first year law students since the Legal Realists, if not earlier. ${ }^{187}$ But if judges are not doing logic, what are they doing, and should they be allowed to continue?

Majoritarian critics reason that if legal reasoning is a myth, if courts are no different than legislatures, if judges are just doing politics, then the judiciary must be a deviant, anomalous institution. In one standard account, a judge "doing politics" is simply an undemocratic usurper, taking from the legislature its rightful role. Worse yet, a judge doing politics in the name of the Constitution sets undemocratic law making above and superior to democracy itself.

Several schools of consequences are drawn from this countermajoritarian problem. One version holds that judges ought to exercise utmost restraint, refraining from making Constitutional decisions unless the law is so clear that the Realist critique does not apply: only if legal reasoning is determinative and logical - for example, when the "plain meaning" of the Constitution is indeed plain should the Court take action. ${ }^{188}$ On a different view, judges ought to

187. To sit on the Sanhedrin, according to the Babylonian Talmud, a judge had to demonstrate that he could prove from the Torah that a "sheretz" is pure, notwithstanding Leviticus 11:29 ("Now these are the ones that are impure among the sheretz."). BABYLONIAN TALMUD, Sanhedrin 17a. That is, a judge had to be skilled enough at legal reasoning to prove the impossible - and therefore to know the limits of legal reasoning. $C f$. R. Meir, of whom the Talmud states that he was such a good reasoner that he was never able to persuade his colleagues. BABYLONIAN TALMUD, Eruvin 13b.

188. Justice Black's plain meaning theory and the "neutral principles" theories of Alexander Bickel and Herbert Wechsler attempt to limit judicial authority to circumstances where the Realist critique seems weak. See, e.g., Beauharnais v. Illinois, 343 U.S. 250, 275 (1952) (reading the First Amendment literally to "forbid[] such laws without any 'ifs' or 'buts' or 'whereases"); see generally ALEXANDER M. BICKEL, THE Least Dangerous Branch: The SUPREME CoURT AT THE BAR OF POLITICS (1962). Although its advocates often refer to this view as "strict constructionism" or "originalism" or similar labels meant to suggest that they are sticking closely to the text, the approach is not text based: as Dworkin has emphasized, it is the theory of the judicial role, not anything in the text, that says that the grand language of the Constitution should be treated by the Courts as if it said nothing at all. See, e.g., RONALD DwORKIN, LIFE'S DOMINION 133-41 (1993); RONALD DWORKIN, LAW'S EMPIRE 368 (1986). Justice Black's reading of the Due Process Clause as incorporating the Bill of Rights has little to do with the text; it is driven entirely by his theoretical concerns regarding the role of constitutional adjudication. See, e.g., Adamson v. California, 332 U.S. 46, 71-72 (1947) (Black, J., dissenting), overruled in part by Malloy v. Hogan, 378 U.S. 1 (1964). Robert Bork's theory that the First Amendment should be read to protect only that speech which any democratic state would have to protect even in the absence of text, is similarly obviously theoretically driven. Robert H. Bork, Neutral Principles and Some First Amendment Problems, 47 IND. L.J. 1 (1971). By pointing out the theory-drivenness of these readings, I do not mean to suggest that another, less ideologically committed, reader could achieve a "pure textualism." The view from nowhere sees nothing. 
strain to read the Constitution as if it set out the rules of democratic procedure for the other branches: the Court should intervene only to perfect democracy, abandoning any attempt to impose substantive values or affect the end results of political struggle. ${ }^{189} \mathrm{~A}$ more peculiar variant attempts to evade the majoritarian critique by assuming that some version of the common law precedes or is above the democratic process, so that a court that enforces only that version of the common law (usually by reading it into the Constitution and then imposing it on courts and legislatures that seek to change or reinterpret it) need not worry about the majoritarian complaint.

For these theorists, judges are just an inferior form of legislature. ${ }^{190}$ Or at least that is all they are when they stray from the "clear" law identified as exempt from the majoritarian critique. Since judges are doing politics without democratic elections, they ought to do so hesitantly, cautiously, and deferentially, for there is little reason to believe that courts will correctly represent popular will.

Others have reacted to the collapse of the law/politics distinction in exactly the opposite way: they have treated legislatures as inferior forms of courts. Identifying not democratic elections but due process, specific factual findings, or moral reasoning as the central pillars of political legitimacy, they have argued that as a rule courts are better structured to engage in deliberative processes than legislatures: courts, unlike legislatures, are required to listen to both sides of a debate, to make reviewable fact findings, and to offer reasons for their decisions. Lacking these safeguards, legislatures seem less

189. See, e.g., JOHN HART Ely, DEMOCRACY AND DISTRUST: A THEORY OF JUDICIAL REVIEW 1-9 (1980). Ely also insists that his "interpretivism" is text-based, but he too relies not on text but on role to explain why the contracts and commerce clauses should be read narrowly and broadly respectively (but in both cases to maximize legislative freedom) while the fundamental principles of democracy - especially one person one vote - should be enforced by the judiciary without any textual warrant whatsoever. Id. While Ackerman does not counsel judicial caution to the same extent, his dual track democracy theory probably also ought to be classified here. ACKERMAN, WE THE PEOPLE, supra note 176, at 3-33. Like Ely, he justifies judicial review on majoritarian grounds: a court relying on the higher democratic moment is, says Ackerman, more democratic than the legislature. The argument is meaningful only if it is the case that were judicial review not majoritarian, it would not be legitimate.

190. I take this to be the sense behind the common and otherwise peculiar use of the "representatives of the people" to include all legislative and executive branch officials (including national officials elected by tiny and non-representative electorates, such as senior senators from small one-party states, and executive officers elected by no one at all), but no judges (including state judges who often have better democratic credentials than the legislatures and agencies who actions they review). Surely Supreme Court Justices are at least as much representatives of "the people" as the senior Senator from Utah: while neither is elected by the American "people," the former, unlike the latter, were nominated by the only nationally elected official we have. Judges are unrepresentative not because they are unelected but because they do not act in the way that legislatures do. 
likely to offer a fair hearing and a reasoned decision-making process. ${ }^{191}$ In a more direct attack on the counter-majoritarian critique, other theorists emphasize that legislatures may be in special need of guidance and restraint due to the problems of majority oppression and the issues I have discussed above under the rubric of the majoritarian problem. ${ }^{192}$

\section{B. The Law/Markets or Politics /Economics Distinctions}

A parallel set of problems (and similarly unsatisfactory resolutions) has bedeviled attempts to define the boundary of economics (or markets) and law (here understood to include both legislature and judiciary). Here too we long ago abandoned the claim that the boundary between "free" markets and their legal regulation is fixed, logical, natural, inescapable, and neutral. As with the law/politics distinction, we are still regrouping from the collapse of the false claim that some particular version of the boundary was inevitable. And here too, some theorists have leapt from the (unquestionably correct) recognition that the boundary is changeable, disputed, controversial, artificial, subject to our conscious manipulation, and highly charged, all the way to a quite different claim that there is no difference between law and economics.

Like those theorists who collapse law and politics, they see not a difficult distinction but no difference at all. Public choice theorists, for example, treat the legislative process as nothing more than a bastardized version of economic market bargaining, in which the pursuit of private interest, unfortunately, leads mainly to inefficiency. The mirror image is a version of neo-Marxist analysis, which sees economic bargaining as nothing more than the power struggle of politics repeated in a slightly different sphere. Without delving into the de-

191. The Court has found this view quite attractive, allowing, for example, race conscious remedies more readily after judicial determinations of past discrimination than in the face of legislative findings of the need to integrate. $C f$. discussion supra note 179 and accompanying text. Compare Swann v. Charlotte-Mecklenburg Bd. of Educ., 402 U.S. 1 (1971) (upholding a complicated district court restructuring of school district urged by the judiciary), with Croson, 488 U.S. at 500, 505 (expressing skepticism about the City's finding of past discrimination in Richmond).

192. See, e.g., Santa Fe Indep. Sch. Dist. v. Doe, 530 U.S. 290, 309 (2000) (finding that a majoritarian allocation of religious rights is unacceptable because it tells nonadherents "that they are outsiders, not full members of the political community") (quoting Lynch v. Donnelly, 465 U.S. 668, 688 (1984) (O'Connor, J., concurring))). These non-aggregative approaches need not be anti-democratic. If the normative system as a whole is subject to democratic consensus, it is possible that the people would prefer to have its implications worked out by experts rather than themselves: just as the people may well (and in the United States often do) decide as a matter of majoritarian preference that many decisions should be made by non-majoritarian market processes. Professor Fiss takes this position explicitly. Owen M. Fiss, Groups and the Equal Protection Clause, 5 PHIL. \& PUB. AFF. 107, 176-77 (1976). 
tails of the disputes, I only note that here too the theoretical tendency has been to jump from the failure of Lochnerism to a total collapse of the distinction-all is market or all is politics. But this is not a necessity: markets can still be different from politics even if they are deeply interdependent and the border between them is a primary focus of both political and economic conflict, discussion and struggle.

\section{The State/Society or Public/Private Distinctions}

A third central theme of legal theory since the New Deal has been the collapse of the state/society or public/private distinction. Once it was recognized that the common law is not a pre-legal, inevitable and non-controversial emanation, but rather a part of the social landscape subject to political, economic and ideological struggle like any other, fixed points break down. What is private or public, where the state or markets should end, is not prelegal or inevitable but rather the premier subject of politics.

Today, Lockean naturalistic labor theories of property seem fundamentally implausible. ${ }^{193}$ We live in an era in which wealth is often entirely intangible and rarely the product of any identifiable human being's labor: software is created by groups, cars are built by firms, even Harry Potter was made possible only by the efforts of many beyond its author. ${ }^{194}$ Moreover, a high proportion of that wealth is concentrated under the control of a small number of multinational corporations answerable only to an impersonal market (or series of markets), with many of the most important rights of common law property held by no human being at all. In this highly artificial, obviously political, contingent and humanly constructed world, it is hard to believe that property has a pre-political or pre-legal existence that could be discovered by examining the state of nature or that can be described by a priori analysis abstracted from particular political disputes or economic needs.

Property may be founded in the right of a man to mix his labor with materials and then to alienate it, as Locke contended ${ }^{195}$-but that theory seems unlikely to lead to useful analysis of, for example, the fair use/Napster/Gnutella issues (does an individual's "ownership" of a CD allow her to allow others to use it, or does the corporate "owner" of the "rights" to the music have the right to charge for additional use?); the externality, tort, and environmental issues (to what extent does use of resources in an economic enterprise come with a concomitant right to impose by which means which costs on third

193. See, e.g., LOCKE, supra note 6, at 18-30 (\$\$ 25-51).

194. See generally SEAN SMITH, J.K. ROWLING: A BIOGRAPHY 130-40, 193-201 (2001).

195. See, e.g., LOCKE, supra note 6 , at 19 (§ 27). 
parties?); the limited liability issues (to what extent should which beneficiaries of an enterprise be responsible for which injuries it causes to which others under which theory of causation?); the rights/liberties conflicts (when should individual autonomy give way to collective decency or simply the boundaries of the public space necessary for us to live attractive private lives?); or, most generally, the limits of property (where do we draw the line between the commons and property rights or between the rights of property to exclude and their abuse?).

The boundaries between state and society, politics and market, individual and collective space, and so on, are not "natural," at least in the sense of unchangeable or beyond human or political intervention. Again, a prominent post-Realist move has been to jump from the recognition that markets require regulation and that private property exists only as defined by the law, all the way to the opposite extreme, collapsing the distinctions altogether.

On one post-Lochner view, society, market and private action disappear altogether. Property is created by the law, and so all law is public, all privacy only a creation of the state. The state's failure to police private exercise of power (in the family, in the market, between the races) is no different from state power itself. Private property is itself a state creation.

On the opposite view, the state is collapsed into the market, as in Coase's invariance theorem, where private actors are imagined to create property rules by private negotiation without (or regardless of) any state or collective decisions at all, or conventional accounts of corporate law, in which the "empty girders" of the law merely ratify inexorable market processes. ${ }^{196}$

Here too as in the other collapsed distinctions, I believe we must proceed beyond both Lochner and its antitheses. The distinctions are neither natural nor clear: but they are essential. Law can be-must be, if we are to live in a civilized way-separated from politics; state from society; state from market; public from private. But interpretation alone will not make the separations we need.

\section{Beyond the Collapsed Distinctions}

With a clearer understanding of the advantages and problems of the available systems, we may be able to proceed beyond a series of debates that increasingly seem to have outlived their interest. ${ }^{197}$ Le-

196. See discussion supra Part III.C.2.c.

197. As a number of authors have recently noted, current fashion in constitutional interpretation is to admit to taking the text quite seriously. See, e.g., Randy E. Barnett, An Originalism for Nonoriginalists, 45 LoY. L. REv. 611, 619-20 (1999) (listing a number of examples). As I have argued, normativity is inherent in the judicial task. Textualism, I think, is largely a proxy for normativity: lawyers find, or create, their 
gal theories that begin by postulating that legislatures are more majoritarian than judges (or less likely to supply normative reasons for their actions) and conclude that judges should (or should not) restrain themselves (or the legislature) simply conceal the harder issue: when should majoritarianism trump normative principles or vice versa. Similarly, debate over economic regulation often degenerates into claims that government is not as market-like as the market, or markets are less likely to fulfill democratic will than legislaturesassuming rather than discussing when one system ought to trump the other. And American political debate seems firmly founded in the somewhat counterintuitive notion that governmental bureaucracies are fundamentally and functionally different from private sector bureaucracies, even when performing similar functions under similar rules.

If we could revive the law/politics distinction without its preRealist overlay of logical necessity, we might be able to clarify this debate significantly. Instead of criticizing courts for not being legislatures and vice versa, we might be able to focus on debating when and where each works or does not, or how to use each at its strengths and to counteract the weaknesses of the others.

I defend a polynomic view. Neither majority will-the core of legislative decision-making-nor reasoned application of pre-existing norms-what judges try to do-are fully defensible, theoretically or practically. Nor is one hierarchally superior to the other. Rather, de-

norms in texts. For the purposes of this Article, indeed, I think it safe to say that we are all textualists - even the most radical originalists, stretching the texts in light of unspoken intentions, and the most radical interpretivists, reading it in light of a commitment to values possibly only partially realized in the text itself. In law, unlike the mythological New Criticism, the text still reigns supreme. At the same time, it is far too late to argue that texts self-interpret. Thus, textualism, in a world of open-textured texts, does not solve the theoretical problems raised by the earlier generation. The issue remains: what authority do judges, applying any available theory of interpretation, have to impose their views on others, especially if, as critics of specific interpretations never fail to remind us, the particular reading of the text is not logically mandatory? Barnett argues that a commitment to writtenness requires, by analogy to contract law, a commitment to original meaning interpretation. Barnett, supra, at 629-48. But a constitution, as Barnett points out, is no contract, not having been consented to unanimously. Id. at 629 . I'd go further: our constitution is fundamentally different from contract precisely because it is part of the framework within which bargaining must occur, and, as discussed in Parts III.B and III.C, the framework will often determine the outcome of the bargaining. At most, it is a quasi-contract - a contract-like expression of social norms - which probably ought to be thought about more in tort terms. That is, it is an attempt to express some fundamental sense of justice that defines the space within which contract-like bargaining takes place. Ultimately, of course, it must retain the allegiance of the people to retain its legitimacy. But its interpretation need not be bound to obsolete moral notions because, as originalism's opponents have noted from the beginning, it is our constitution, not the Founding Generation's. 
cent societies will use some combination of aggregation-based decision-making processes-which attempt to aggregate pre-existing preferences and beliefs of citizens-and normative systems-which attempt to articulate the reasons and logic of existing principles. Thus, I place myself firmly in the pluralistic tradition of the United States Constitution: our different decision-making systems serve irreducibly different values, and that is the way it should be.

In this Article, I have attempted to elide the internal debates within each decision-making system in order to more clearly set out the differences between them. Even this highly generalized treatment, will, I hope, help to lay the groundwork for discussions of such disparate issues as:

- why judges (including elected state court judges with reasonable majoritarian credentials) defer to law with only poor democratic credentials (including, for example, common law, antique legislative enactments, the older parts of the Constitution, and Delaware's corporation law) and when or whether they are right to do so.

- whether it is right to accord federal judges greater respect than state court judges even when the latter are elected.

- the limits and strengths of democracy-based claims to states-rights or federalism.

- the institutional basis (or lack of foundation) for the Supreme Court's recent attempts to retake for itself the authority to determine the limits of Congressional authority to define its powers over the states.

- the continued vitality (or lack thereof) of the state action requirement in a world in which the largest aggregates of private power far outweigh most state power units, in which the state is far less unitary in its goals than the market, and where in both state and private sectors the key and highly contested issue is the proper place of the market's drive to constant flux and mobility within an ever increasing concentration of wealth.

I hope then to revive the law/politics distinction in a new form: a market/democracy/bureaucracy/civil society distinction. The institutions exist; let us analyze them not as poor imitations of each other but as fundamentally different expressions of fundamentally different values. Rather than choosing one of efficiency, majoritarianism or expertise and normativity as a yardstick with which to judge all our institutions, we need a more complex conflict of internal and external standards..$^{198}$

In this Article I have attempted to restate the four basic collec-

198. See, e.g., WALZER, SPHERES OF JUSTICE, supra note 40 , at 312-21. 
tive decision-making systems of a modern democracy, along with brief discussions of their principle strengths and weaknesses. With a clearer understanding of the advantages and problems of the available systems, we may be able to proceed beyond constitutional law theories that begin and end by postulating that legislatures are more majoritarian than judges (or less likely to supply normative reasons for their actions) and therefore conclude that judges should restrain themselves (or the legislature). Legislatures are supposed to be majoritarian, judges are supposed to be normative-but we cannot merely assume that democracy trumps normativity or vice versa. Similarly, economic regulation talk often degenerates into claims that the government is not as market-like as the market, or that markets are less likely to fulfill democratic will than legislaturesassuming, rather than discussing, when one value ought to trump the other.

I do not pretend to offer a theory of the appropriate spheres for each decision-making system in this Article. But I do hope to have shown that no one can claim supremacy over the others. It is not a valid argument against judicial review to call it a deviant or countermajoritarian institution, nor is it a valid argument for judicial supremacy to state that legislatures are unprincipled. Markets may be validly criticized for being inefficient, but sometimes efficiency is not the proper goal; and then even, or especially, efficient markets will have to be replaced with civil society, majoritarianism or even normapplying bureaucrats. The central concern of this Article is to suggest a way of resurrecting the law/politics and the market/politics distinctions without committing to a deeply implausible theory of legal epistemology. 